\title{
Teachers Civic Education and Their Methodological Skills Affect Student Engagement in Civic Participation
}

\author{
Dr. Lindita Lutaj \\ University "Aleksander Moisiu", Faculty of Education, Department of Pedagogy, Albania \\ Email: I.lutaj@yahoo.com
}

\section{Doi:10.5901/ajis.2016.v5n3s1p336}

\begin{abstract}
Civic education is important, because the society needs people to contribute in the most effective way. The teacher plays an important role in encouraging pupils to civic actions. The aim of this study is find out the relationship between teachers civic education and their methodological skills in students civic participation. The statistical package of social sciences (SPSS 20) was used for data analysis. Questionnaires were administered to 34 teachers who give social education subject in $6^{\text {th }}$ - $^{\text {th }}$ grade and 414 students of these teachers, in Durres and Elbasan. The factorial analysis of the questionnaire on teachers civic education discovered two important factors: civic responsibility and civic values, while according to teachers' methodological skills discovered three factors: the quality of the class, learning and student assessment. It was also observed that there is a positive relationship between teachers' civic education and their methodological skills with students' civic participation, which it was reported by teachers or perceived by students. There is a significant statistical relationship between teachers civic education and students civic participation: $r=.40(p<0: 01)$, which is stronger than teachers methodological skills and students civic participation: $r=.28$ ( $p<0: 01$ ). According to the findings of this study should be increased teachers training programs at local and national level. A great importance should be given to civic education in the school curriculum and universities should recognize their responsibilities in preparing future teachers.
\end{abstract}

Keywords: Civic education, methodological skills, civic participation.

\section{Introduction}

The main purpose of education for the democratic civilization is to develop, strengthen and protect the democratic culture of the rights and responsibilities, as the foundation of the efficient voluntary and stable actions of citizens. As such an action, education is closely linked to the acknowledgement and obligation to the common democratic values; to the institutions and the procedures that guarantee their further protection and development. Among others education aims to offer continuous chances in order to obtain, implement and distribute information, values, expressions and proper practices in all formal and informal educative environments. Reports of Birzea, 1996 (Education for Democratic Citizenship, document DECS/CIT, (1996)1, Veldhius, 1997 (document DECS/CIT(1997) 23 and Audigier, 1999. (EUD/CIT (1999) 53, Hahn (1998), in a comparative study of education for the civil rights found that there are statistical changes between the countries according to the teaching traditions and cultural norms. This article explains that methods and civil education programs can not be used without any addoption from one country to another and are expected to function successfully, as each country has its particular conditions.

Raising the citizens in the civil levels is achieved by preparing them for a conscious participation and responsibilities in the political and social life. This preparation, mainly based in values and principles of democracy should be understood as being equipped with knowledge, intelectual expressions and phrases of democratic actions (Democratic Civil Education in Albania, pg.21).

The active civilization is a important issue in the Lisbone program. The European Commission promoted three main pillars, one of them is "learning for an active citizenship". In the detailed work program for following the education and training systems in Europe, the European Council has formulated 13 objectives related to the Lisbone program, where the objective 2.3 has to do with "The support of active citizenship, equal chances and social cohession". The main mentioned issues in the work program related to the active citizenship are "To ensure that the education of the democratic values and participation from all is promoted effectively in order to prepare people for active citizenship" (Indicators for Monitoring Active Citizenship and Citizenship Education, 2005, pg. 7).

Education for the democratic civilization goes beyond the school boundaries, challenging the separation of between formal and informal education. There should be more objective conclusions in the direction of evaluating the 
http://www.spiegel.de/international/spiegel/the-third-reich-how-close-was-hitler-to-the-a-bomb-a-346293.html,

Miller, Marvin and Scheinman, Lawrence, Israel, India, and Pakistan: Engaging the Non-NPT States in the Nonproliferation Regime, Arms Control Association, December 1, 2003, accessed at https://www.armscontrol.org/act/2003_12/MillerandScheinman.

Moeed Yusuf, Predicting Proliferation: The History of the Future of Nuclear Weapons, Policy Paper, Number 21, Boston University, January 2009

Richard Cavendish Published in History Today Volume 52 Issue 10 October 2002, http://www.historytoday.com/richard-cavendish/firstbritish-atomic-bomb-test.

The Acheson-Lilienthal \& Baruch Plans, 1946.

The Baruch Plan, The US Presented Baruch Plan. June 14, 1946, accessed at http://www.history.com/this-day-in-history/the-unitedstates-presents-the-baruch-plan.

US delegation to the 2010 Nuclear Nonproliferation Treaty Review Conference, 2010 NTP, Treaty of the Non-proliferation of Nuclear Weapons, accessible on Google free access.

Yusuf, Moeed, Predicting Proliferation: The History of the Future of Nuclear Weapons, Policy Paper, Number 21, Fellow, Frederick S. Pardee Center for the Study of the Longer-Range Future, Boston University, January 2009. 
established a sufficient legal framework to control the spread of nuclear materials and expertise. More than that, the signatories of this Treaty, vowed not to take any action that would increase the number of countries with nuclear weapons. ${ }^{19} \mathrm{~A}$ signatory of the treaty are 190 member states, including five countries with nuclear weapons. ${ }^{20}$ Many countries have also ratified. Israel, India and Pakistan have never been a signatory of the Treaty. North Korea, which had acceded to the Treaty in 1985, withdrew from it in 2003. ${ }^{21}$

Treaty without any changes so far assumes that states that do not possess nuclear weapons, and which are parties to the treaty must not produce or purchase nuclear weapons or other explosive nuclear devices. But for the existing nuclear-armed states, the treaty does not require and does not oblige to submit their nuclear weapons, but recommends them to negotiate between them in good faith to eliminate such weapons. For non-nuclear weapon states (NNWS Non-Nuclear Weapon State) there is no room for negotiation. Consequently, the treaty has created two classes or groups of countries, such as: countries with nuclear weapons and country without nuclear weapons. ${ }^{22}$

It should be emphasized that as a case today DPRK (North Korea Nuclear Program) and Iran belongs to the second group of states without nuclear weapons. The research question can be arisen in giving clear answer the legal framework of international nuclear security in preventing the spread of nuclear weapons in the North Korea, whether is sufficient or it is a necessary an additional deal creating a free zone of nuclear weapons?

The answer it is that a best solution at the moment for all humanity it can be if the negotiations would come to an end by signing the agreement which would establish a Nuclear Free Zone without Nuclear Weapon.

\section{Conclusion}

Scientific thoughts on the meaning and definition of the concept of international security, particularly in nuclear security cannot be understand without elaborating in detail the genesis and effort of many stakeholders toward signing the NPT.

Elaboration of the genesis efforts above, it is important for the international legal framework on nuclear safety, because the regulation of the relations in this issue, between the parties and international actors (states, organizations and international agencies and different groups of interest) cannot be understood fully unless can be understood the history of nuclear international security in general. Also the completion of this framework in the sphere of nuclear security as a part of historic deal it is very gapufully understand unless analyzing the actions of stakeholders toward reducing the nukes and signing the NPT.

Whatever the concern, the global security is becoming day by day current topic, pushed by the different modalities of the threats to all of human values and the necessity of their protection.

\section{References}

Borger Julian, The truth about Israel's secret nuclear arsenal, The Guardian, Wednesday 15 January 2014 18.18 GMT, accessed at, https://www.theguardian.com/world/2014/jan/15/truth-israels-secret-nuclear-arsenal.

Committee on technical issues related to ratification of the comprehensive test ban treaty -Technical issues related to the comprehensive nuclear test ban treaty, National Academy Press Washington, D.C., 2002.

Etemikef Laz, The Politics of nuclear non-Proliferation, Cejiss 3-4/2012.

FAS (Federation of American Scientists), A Brief History of Pakistan's Nuclear Program, http://fas.org/nuke/guide/pakistan/nuke.

http://midtermpapers.com/essays/peace-is-the-sturdy-child-of-terror-for-me-such-a-peace-is-a-wretched-offspring-a.

https://www.ctbto.org/specials/testing-times/13-february-1960-the-first-french-nuclear-test,

http://www.history.com/this-day-in-history/china-joins-a-bomb-club.

India-Pakistan: Nuclear Weapon Update, The Risk Report, Volume 4 Number 6 (November-December 1998), accessed at http://www.wisconsinproject.org/countries/pakistan/nuke98.html,

Klaus Wiegrefe, The Third Reich: How close was the Hitler to A-Bomb? Spiegel online international, Ausgabe 11, 2005,

\footnotetext{
${ }^{19}$ Etemikef, Laz, The Politics of nuclear non-Proliferation, Cejiss 3-4/2012, p. 16.

20 NPT defines a nuclear weapons state, the state, which has manufactured and exploded a nuclear weapon-test or other nuclear device before 1 January 1967. These countries are: China, France, Russia, UK and USA. All other states are states with non-nuclear weapons under the Treaty.

${ }^{21}$ Miller, Marvin and Scheinman, Lawrence, Israel, India, and Pakistan: Engaging the Non-NPT States in the Nonproliferation Regime, Arms Control Association, December 1, 2003, accessed at https://www.armscontrol.org/act/2003_12/MillerandScheinman, visited at 08.11.2016.14:35.

${ }^{22}$ Etemikef Laz, The Politics of nuclear non-Proliferation, Cejiss 3-4/2012, p.16.
} 
successfully possess nuclear capability. ${ }^{11}$

Since the beginning of this nuclear era, the international community continually had tried, to reduce the risks posed by the existence of nuclear weapons proliferation. Furthermore the environmental risks from explosions of nuclear tests in the atmosphere had increased the danger as a result of the competition of nuclear weapons, has triggered various initiatives from the very early design for international legal norms aiming to limit nuclear testing. ${ }^{12}$

In the framework of this initiative we can distinguish a statement of British Prime Minister Winston Churchill, were according to him, the "Peace is the sturdy child of terror. For me, such a peace is a wretched offspring, a peace that condemns us to live under a dark cloud of perpetual anxiety, a peace that codifies mankind's most murderous instincts. . . The beast (nuclear weapons) must be chained, its soul expunged, its lair laid waste." ${ }^{13}$ Contrary to this initiative idea it exist group of thinkers who deal with this issue and believed and still believe today on the deterrence of states by the using of these weapons. They usually assume that such weapons can be controlled by a small number of major responsibility powers. Therefore, this theory presupposes the nuclear monopoly, which underscores the logic of the early non-proliferation, given the permanent members of the Security Council of the UN Security Council (the more powerful chamber of the international community). ${ }^{14}$ One of the significant effort for nuclear non-proliferation, after the World War II can be considered that beginning of the adoption of the so called Baruch Plan of Truman Administration, where Acheson-Lilienthal's report(1946) proposed to verify disarmament and eventual destruction of U.S nuclear arsenals (the only nuclear arsenal at that time). Truman's administration felt and believed so "naive" that doing so would reduce international tensions in the future and eliminating the arms race in this area. ${ }^{15}$

Unilateral disarmament of US never happened, and finally Baruch Plan was abandoned after the Soviet Union soon produced its own WMD. When US President Eisenhower took office, he laid out a program called "Atom for Peace" (1953), which will bring a sort of degree to international transparency in nuclear technology race and who will lead to a general system of safeguards nonproliferation nuclear weapons. ${ }^{16}$ The "Atom for Peace" was followed by the establishment of the International Atomic Energy Agency (IAEA 1957), which at the beginning was not so serious effort until 1960, in reaching an international agreement on limiting nuclear proliferation. Until the above mentioned process the USSR, France and Great Britain have reached their possession of nuclear weapons. The Eisenhower said the international community had to wait eight years with the threat of spreading tension, while nuclear armed states agreed to halt the spread. ${ }^{17}$

By analyzing also a statement of US President John F. Kennedy, delivered at a press conference, on 23 March 1963 before signing the NPT, which described a world where up to 1970 may own more than 10, 15 or more than 25 nuclear weapons countries, then there is a "greater potential risk and a game of chance with life on earth." From this declaration can be concluded that at that time he saw more potential that could soon spread the nuclear weapons. Therefore the beginning of the 1960s, efforts to reach a legally binding agreement to prevent the further spread of nuclear weapons, began to intensify, and showing the results. Even the United Nations General Assembly, in 1961, adopted a resolution sponsored by Ireland urging all states to reach an agreement that would ban the purchase and transfer of nuclear weapons further. As well as in 1965, the Geneva Conference on Disarmament began in drafting the treaty on nuclear nonproliferation. ${ }^{18}$ This consensus between states were regulated and sanctioned by the Non-Proliferation Treaty (NPT), which entered into force in March 1970. Scientists like Richard Kokoski, research SIPRI (Stockholm International Peace Research Institute) for military technology and project control of the weapons, argued that the NPT has

\footnotetext{
${ }^{11}$ Borger Julian, The truth about Israel's secret nuclear arsenal, The Guardian, Wednesday 15 January 2014 18.18 GMT, accessed at, https://www.theguardian.com/world/2014/jan/15/truth-israels-secret-nuclear-arsenal, visited at 08.11.2016.

12 Committee on technical issues related to ratification of the comprehensive test ban treaty -Technical issues related to the comprehensive nuclear test ban treaty, National Academy Press Washington, D.C., 2002, preface, p vii.

$13 \mathrm{http}: / /$ midtermpapers.com/essays/peace-is-the-sturdy-child-of-terror-for-me-such-a-peace-is-a-wretched-offspring-a, visited on 20.07.2016, 23:55.

14 The Baruch Plan, the US Presented Baruch Plan. June 14, 1946, accessed at http://www.history.com/this-day-in-history/the-unitedstates-presents-the-baruch-plan, visited on 08.11.2016.

15 The Acheson-Lilienthal \& Baruch Plans, 1946, accessed at https://history.state.gov/milestones/1945-1952/baruch-plans visited at 18.11.2016, 11:13.

16 Etemikef, Laz, The Politics of nuclear non-Proliferation, Cejiss 3-4/2012, p. 15.

17 Ibid, p. 15-16.

18 US delegation to the 2010 Nuclear Nonproliferation Treaty Review Conference, 2010 NTP, Treaty of the Non-proliferation of Nuclear Weapons, accessible on Google free access.
} 
World War II will not end with that, and nuclear proliferation will continue further, followed by the United Kingdom in October 1952, ${ }^{4}$ France, ${ }^{5}$ and Communist China. ${ }^{6}$ Also India ${ }^{7}$ and Pakistan ${ }^{8}$ demonstrated their internal nuclear capabilities, although these were not considered applicable to full nuclear rights, while they tested their nuclear weapons ambitions in $1998 .{ }^{\circ}$ Canadian scholar Ashok Kapur after the India test predicted that trend of proliferation would be increased. He suggested that weaponized would be countries as follow: Israel, Japan, Australia, South Africa, Brazil, South Korea, Taiwan, and Argentina as countries widely perceived as potential nuclear states. ${ }^{10}$

However, although it remains far unverified, it is assumed that only Israel since 1950 covertly was able

forecasting that Russian can produce a bomb in middle of 50s, although the most probable date was still predicted to be mid-1953. The estimate has been made just five day in an August 1949 report disseminated five days before the actual Soviet atomic test. Following the test, American forecasts about the Soviet Union transitioned into examinations of the relative strengths of the two sides. Forecasts regarding the nuclear capability of the two superpowers saw a progressive shift of balance in Moscow's favor. After the test regarding the nuclear capability of the two superpowers had been made a progressive shift of balance in Moscow's favor. Some prediction in 1950s, were very shocking for US administration, were some related projections pointed to the probable accelerated modernization of the Soviet nuclear arsenal in an attempt to gain parity with the United States. However, in the early-to-mid 1960s, after the Berlin and Cuban missile crises, U.S. intelligence assumed that the Moscow would abandon its motivation and ambition to gain a substantial advantage over Washington. But another estimation in the late 1960s, and by the year of 1969 National Intelligence Estimate (NIE) stating that the USSR would seek "parity with the U.S.". This would be reached by soviets not only by incising number of atomic bombs but as well they will be focused on qualitative comparison with American nuclear forces. During the late-1980s, when economic frailties and internal political turmoil had made any talk of Soviet military supremacy redundant, the CIA's view prevailed in most forecasts. For more visit at Moeed Yusuf, Predicting Proliferation: The History of the Future of Nuclear Weapons, Policy Paper, Number 21, Boston University, January 2009. p. 8-9.

${ }^{4}$ British also had developed its own atom bomb to remain a great power and to be independent from United States... After secret meeting committee discussed the question in October 1946, By the time the bomb was ready for testing, the Churchill government was in power. The scientific director was to be Dr. W.G. Penney, the ministry's chief superintendent of armament research, a nuclear physicist who had worked on the world's first atomic bomb in America. A combined British and Australian naval force of aircraft carriers, a destroyer, frigates and tank landing ships was assembled for the operation. The bomb was put in an anchored frigate, HMS Pym, and when it exploded at 8am local time on October 3rd thousands of tons of rock, mud and sea-water were blasted into the air. 'For more visit, Richard Cavendish, Published in History Today Volume 52 Issue 10 October 2002, http://www.historytoday.com/richardcavendish/first-british-atomic-bomb-test, visited on 20.07.2016.18;20.

${ }^{5}$ On 13 February 1960, France conducted its first nuclear test, code-named "Gerboise Bleue" (Blue Desert Rat). This atomic bomb comparing with Hiroshima's bomb around four times more powerful. Subsequent French nuclear testing was conducted at French Polynesian atolls in the South Pacific, site of atmospheric thermonuclear tests, starting with the 2.6 megaton Canopus test in August 1968. For more visit at https://www.ctbto.org/specials/testing-times/13-february-1960-the-first-french-nuclear-test, 20? 07/2016, 18:26.

${ }^{6}$ The People's Republic of China joins the rank of nations with atomic bomb capability, after a successful nuclear test on this day in 1964. China became the fifth member which is coincidence with permanent member of Security Council at the United Nations. The attention to get a nuke in her hands China started at early at 50s For that the U.S. officials were not terribly surprised by the test The Russian experts had helped the China to get the $A$ bomb , who later after the split would be very concern of it regarding the ideological and strategic issues. This test increased the tensions between the two nations. For more visit on http://www.history.com/this-day-inhistory/china-joins-a-bomb-club, 20.07.2016, 18:32.

7 India as well conducted its first nuclear detonation, called by India as a "peaceful nuclear explosion," on 18 May 1974. This test was partially successful. It is reported that the American intelligence community estimated that the actual yield was in the range of 4 to 6 kilotons. High-resolution commercial satellite imagery. Calculated that the radius of substantial area was about 60 meters, and is surrounded by a distinctive perimeter with a radius of roughly 80 meters. For more visit at, FAS (Federation of American Scientists), http://fas.org/nuke/guide/india/nuke/first-pix.htm, visited on 20.07.2016, 18:09.

${ }^{8}$ On May 28, 1998, Pakistan stated that it had successfully committed five nuclear tests. This statement also is proven by The Pakistani Atomic Energy Commission who reported that the five nuclear tests conducted which generated a seismic signal of 5.0 on the Richter scale, with a total yield of up to 40 KT (equivalent TNT). On May 30, 1998 Pakistan tested again another nuclear warhead. The tests were conducted at Baluchistan, bringing the total number of claimed tests to six. For more visit on, A Brief History of Pakistan's Nuclear Program, for more visit on FAS (Federation of American Scientists), A Brief History of Pakistan's Nuclear Program, http://fas.org/nuke/guide/pakistan/nuke/, visited on 20/07/2016, 18:44.

9 India-Pakistan: Nuclear Weapon Update, The Risk Report, Volume 4 Number 6 (November-December 1998), accessed at http://www. wisconsinproject.org/countries/pakistan/nuke98.html, visited at 08.11.2016.

10 Yusuf, Moeed, Predicting Proliferation: The History of the Future of Nuclear Weapons, Policy Paper, Number 21, Fellow, Frederick S. Pardee Center for the Study of the Longer-Range Future, Boston University, January 2009, p. 21. 


\title{
From the First Nuclear Explosion up to the Signing of Non-Proliferation Treaty of Nuclear Weapons
}

\author{
Mentor Lecaj \\ PhD student in the field of International Law, \\ Lecturer in subjects "International Law" and "European Law", \\ Faculty of Public Administration - AAB College, Pristine
}

Doi:10.5901/ajis.2016.v5n3s1p331

\begin{abstract}
Since the beginning of this nuclear era, one part of the international pacific community continually had tried, to reduce the risks posed by the existence of nuclear weapons proliferation. The environmental risks from explosions of nuclear tests in the atmosphere had increased the danger as a result of the competition of nuclear weapons triggered various initiatives from the very early design for international legal norms aiming to limit nuclear testing. This work paper tries to, describe, discuss and analyze historical data on political spirit before signing the NPT. More over this article considers and trying to give interpretations to the official political statements and declarations on unpredictable issue for the future, which it might have serious consequences for international security. The findings in this article are that competition of nations in having nukes and increasing their numbers and capabilities are one the main part in chain reaction factor that can bring proliferation in high alert and humankind in greater risk situation
\end{abstract}

Keyword: Historical data, NPT, Peaceful use, Noncompliance activities, Security

\section{Introduction}

This article provides historical data on effort taken by main international stakeholders aiming to reduce the risk from nuclear nonproliferation.

As a paper work which aims to give an outlook on genesis of nuclear weapon and official statements from most important official person at that time can be feel the spirit of danger exist and can be occurred in future.

Importance of this work is related very closely in raising the awareness of humankind in era we are living.

\section{From the First Nuclear Explosion up to the Signing of Non-Proliferation Treaty of Nuclear Weapons}

United States were the first state to test and opened the doors for Weapons of Mass Destruction (henceforth -WMD). ${ }^{1}$ The Manhattan Project, it was he who brought the production of nuclear weapons, and which had been used on two Japanese cities, Hiroshima and Nagasaki. These bombings on the one hand helped in ending World War II, while on the other side opened the beginning of a new era in the field of international law and international relations, regarding global security. ${ }^{2}$ The USSR (Soviet Union) in trying to balance US in opposing in every field of social life (political, economic, military), successfully tested in 1949 its first nuclear weapon. ${ }^{3}$ The rivalry contest between the main winning countries of

\footnotetext{
1 It is very interesting to be emphasized that Germans were the first who planned an atomic bomb. Today are some written books, example by historian Rainer Karlsch who states that Germans were the first who tested the three test of atomic bomb, 1944-45. But this theory is not profaning yet. But what is proved is that Germans were the fist who planned to get an atomic bomb. For more visit the Klaus Wiegrefe, The Third Reich: How close was the Hitler to A-Bomb? Spiegel online international, Ausgabe 11, 2005, http://www.spiegel.de/international/spiegel/the-third-reich-how-close-was-hitler-to-the-a-bomb-a-346293.html, visited on 19.08.2016. $14: 49$.

${ }^{2}$ The Baruch Plan, The United States Presents Baruch Plan, June 14, 1946, accessed at http://www.history.com/this-day-in-history/theunited-states-presents-the-baruch-plan, visited at 18.11..2016, 10;45.

3 The race between two superpowers will start during World War II. In both side when we analyses the evidences from today perspective we conclude that they were in panic that is going to dominate whom. The American intelligence were convinced and assumed in August 1946, suggesting that Moscow could produce an atomic device between 1950-1953. But in 1948, they estimated an early date 
impossible to foresee what would be the alternative ground.Lack of information on the alternatives and values compel the former owners to choose between continuing their complaints and receive compensation. The principle of return and compensation for families whose property was confiscated during the Communist era, was added in the Albanian law 1993 because land distribution programs for farmers, villagers and privatization of apartments were being conducted.So laws must resolve claims conflicts between new owners (those who won their rights under the post-privatization legislation of 1991) and the former owners.

\section{References}

Galgano Francesco, "Private Law", Luarasi University, Tirana 2006.

Agency for the Legalization, Urbanization and Integration of Informal Areas, Meeting with the donors 1.Year 2009.

Juliana Latifi, Set of lectures, The ownership, UET.

Arben Puto, Political Albania (1912-1939).

Ardian Nuni, "Lectures of the right of ownership" Tirana 2002.

History of Albania and the law in Albania, Luarasi, Tirana.

Constitution of the Republic of Albania.

The 1994 Civil Code.

The 1929 Civil Code. 
Following the law sanctions that the land can not be exclusive of the state, as this gives you the land natural and legal persons who exercise the right of ownership or other rights would be recognized in that law.One such right is the right of use. This legal transaction of agricultural land from the state to local natural or legal person is done without compensation. Unlike their foreign domestic entities may be granted only land to use for rent. The law makes a detailed arrangement of transfer of agricultural land to a private entity can be classified as:

- Member of the families partakers on agricultural cooperative.

- Member of the families residing in the village, but that has not been a member of the agricultural cooperative.

- Member of the families living and working in agricultural enterprises.

Regarding the right of members of a farming family to be treated with agricultural land under Law 7501 " For the Land " and the obligation of the Commission of land in the village and the municipality to address the request of the parties concerned, This kind of relationship has been part of the unifying practice of the United Chambers of the Supreme Court.

\section{Property Restitution and Compensation of Former Owners}

Regulating the issue of property after communism is different from other ownership changes made throughout history. This is comparable with the nationalization of all industries (eg mining) or secular church property.lt is comparable only to the process of establishing socialist collective ownershipwhich aimed total liquidation of private property. The return of private property and a market economy in the former socialist countries is an extraordinary historical process. The first law on property restitution and compensation belongs to 1993, its adoption was accompanied by controversy and a great debate both public and legal. The issue was discussed with the debate on the return of farmland that began in 1993 when the original law no. 7698, for the return of property to the former owners. In the framework of the Constitution the new Law no. 9235 dated 29.07.2004 was drafted for property restitution and compensation. The new law, that of 2004, for property restitution and compensation of several problems of the law of 1993.It had the same initial order, restitution and compensation of immovable property expropriated, nationalized or confiscated during November 1944. This law recognizes a wider number of complaints and plaintiffs that the previous law but continues to exclude agricultural lands that are subject to the Law no. 7501.To determine the degree of restitution / compensation court was based on the market value and the other hand to apply this method of evaluation court requires two conditions:

- First to show that in determining the suitability of a particular act by a country that had to do with issues of land and property any interference in the exercise of these rights should establish a fair balance between the aim sought to be achieved and the nature of the act.

- Second, each pretender for restitution or compensation should have the right to an independent court, impartial that will determine his complaints rapidly and effectively.

\section{Conclusions}

From all panorama presented above, I can say unequivocally about the history of relations on the ownership role of the state in this regard, other problems that have accompanied the processes of control and administration of the territory, Albania constitutes a special occasion.Seeing the drastic measures taken by the regime communist for nationalization total ownership, abrogation of the existing legislation on property, validation of concepts communist on joint property and the administration of the territory, and implement radical reforms aimed expropriation mass of owners worsened in a sensitive way the welfare level of the population and negatively affected the country in the development of Economics.Dismemberment of the communist system in Albania, as in the ideological aspect as well as in the economic, and the transfer of land in the difficult period of transition to a market economy and the consolidation of democracy was accompanied by the birth and development of a series of economic and social phenomena, which related to the demographic movement of people from rural to urban areas.Also rapid developments were happening in the construction sector in Albania but rising fast paced could not be controlled from the legal framework inherited from the communist regime, the legislation in force proved to be insufficient to be applied quickly and effectively to control this important sector that was greatly complicated bringing heavy distortion due to urban development of cities. The phenomenon of informality in construction affects the whole territory of the Republic of Albania with focuses mainly in suburban areas.Continuing delays in resolving the issue of compensation and restitution caused a circular dilemma, prevented the land and property rights in many areas.In one side location and boundaries of state property can not be clearly defined until turned parcels and private plots would be defined.On the other side, until state properties were determined it was 
the contrary. This new popular regime came as a progressive stream to the spirit of communist ideas, which meant that every citizen of the working class would not feel oppressed and inferior by the wealthy class.On the basis of these utopian ideas for the state during the years 1945-1990 would be led by an oligarchy institutionalized individuals whom in Albania not only the welfare, but also the health of citizens, but the dictatorship of the proletariat thus undermining any economic freedom, political and social which were placed before 1939. Thus the state guaranteed the prices, but did not guarantee citizens' needs for accommodation, goods, services and other vital needs ${ }^{2}$ [V.Duka,History of Albania 19122000]. This was the time when it was removed the right of private ownership and became expropriation of buildings constructed by violating every right of the individual as owner.Expropriations made by the regime were not the same for all categories, as they were made according to a specific plan by the regime itself in order to have everything in control.

\subsection{The situation of the property in 1989 .}

In 1989 all Albanian lands were owned by the state. The principle of exclusive state ownership was sanctioned in the Constitution of $1976^{3}$ [See Constitution of the People's of Albania], this was the final legal action to prohibit any other form of collective rights or private property in land.By the end of the 80s, there was a broad opinion that the economy was in crisis. The causes are found in a series of distorted economic policies, but strict control of land was an important element, especially for the agricultural crisis.Ministry of Agriculture and Food has explained the political and economic origins of the land reform in this way ${ }^{4}$ [World Bank,Report of 1992] 1990 agriculture constituted deficiencies in the national economic system. While it constituted $52 \%$ of GDP and employed $54 \%$ of the total national labor force, the government drew profit from the production of farm but gave back a very small portion as payment and investment. When rural population was growing at $3 \%$ per annum; agricultural output grew by only $0.03 \%$ as a result of low financemnet and lack of investment. "Legislative change came in 1991, when under conditions of crisis, the parliament adopted the law on the Constitutional principles of 1991, which rejected the Constitution of 1976 and served as the basic law until the drafting of the new constitution of 1998. The law referred to private ownership of land and forced the state to develop economic relations based on market principles. He would force the Parliament and the Government to review the structure of ownership of land and real estate in Albania.

\section{Steps Towards Recognizing and Sanctioning Private Property. The Period after 90s}

The overthrow of the dictatorship and establishing democracy pitted Albanian state and society to a large number of challenges and reforms that had to be overcome.The transition from a system where the government was the sole owner in a system where there is private property demanded not only a legal, economic and institutional reform but demanded that people foremost radically change their concept for the property ${ }^{5}$ [Juliana Latifi, Set of lectures UET]. One of the key reforms that were undertaken in this period was the adoption of the law the No. 7491 dated 04.1991 " for major Constitutional provisions " by means of which was abrogated the 1976 Constitution.In Article 11 of Law no. 7491 is expressed " subject to the right of ownership are state, legal and physical persons'.All kinds of ownership enjoy equal protection by the state. With the repeal of the 1976 Constitution the state has lost the right to be the sole owner of land in the Republic of Albania.In 1991 the Albanian government started land reform and immovable property relations by improving the existing Civil Code (1981), authorizing transactions ranging market and transfer of agricultural, residential and commercial property in the ownership of citizens and legal persons.

\subsection{The first laws for the distribution of land and property privatization.}

Three new laws adopted in 1991-1992, started programs transfer ownership rights on land and real estate from the state to citizens and legal persons. These laws included a mix of elements defining the relationships of people with the tangible objects of immovable entitlements and land. Some elements were held by the communist period were taken by other European civil codes.Law No. 7501, For the Landauthorized under the allocation and transfer of land to family members of the collective farms in equal parts.Law No.7501 date 19/07/1991 "For the Land" was the first time that we would sanction the right of the individual to the land. Object of the law is above all land and agricultural land. Article 1 of this law characterizes the land:

- Agricultural land

- $\quad$ Land occupied by forests, pastures and meadows.

- Agricultural land (land not included in the above two points) 


\title{
Property Rights in Albania: Historical Background and Current Issues
}

\author{
Phd. Adrian Leka \\ Faculty of Law, "Luigj Gurakuqi" Universitety \\ Email: leka-ad@live.com
}

\section{Doi:10.5901/ajis.2016.v5n3s1p327}

\section{Abstract}

Dismemberment of the communist system in Albania as the ideological aspect as well as in the economic, and the transfer of land in the difficult period of transition to a market economy and the consolidation of democracy was accompanied by the birth and development of a series of economic and social phenomena, which related to the demographic movement of people from rural to urban areas. Similarly, the construction sector experienced rapid development, but fast paced growth could not be controlled by the legal framework inherited from the communist regime.Effective legislation proved to be insufficient to be applied quickly and effectivelyto control this important sector that was excessively complicated by bringing heavy distortion due to urban development of cities. The phenomenon of informality in construction today affects the whole territory of the Republic of Albania and focuses mainly in suburban areas. Immovable property represents in the Republic of Albania today a special interest in relation to social economic and political developments that our country is going through. The right of ownership is accepted by society and the system in which we live because of fundamental importance, acceptance of private property is not done verbally, but it is sanctioned in the most important document of the state, in the Constitution of the Republic of Albania.To put in writing indicates willingness to respect this right, to guarantee the safety and protection.In order to exercise the right of private property in practice, the individual must own a private property recognized as such.Immovable property represents in the Republic of Albania a special interest in relation to social economic and political developments that our country is going through. The right of ownership is accepted by society and the system in which we live.Due to the fundamental importance of the acceptance of private property is not done verbally, but is written in the most important document of the state, in the Constitution. To put in writing indicates willingness to respect this right, to guarantee the safety and protection.In order to exercise the right of private property in practice, the individual must own a private property recognized as such. Our previous system considered all property as common property ie anyone's or everyone's. If private property is not recognized by the Constitution and is not reflected in other laws, its absence allows and encourages theft, misuse of property and creates obstacles for the development of the country.

\section{Property along the Existence of the Albanian State. The Period from 1912-1945}

After the declaration of independence and the creation of a genuine Albanian state freely and independently for the first time, it was necessary the creation and restructuring of state institutions through the issuance of laws for this purpose.The functioning and organization of the state firstly as a republic and then as a monarchy will be characterized by the revival of the system of law in Albania.So the government of Ismail Qemali although made some changes and legal regulations in some respects, left in force temporarily until the issue of a new law, the laws that existed during the Ottoman occupation where one of these laws which continued to exist was the legal regime of land until 1925 was governed by the law of the land to the year $1856^{1}$ [Dudaj,Tirane 2010].An important step represents the Civil Code of Albanian Kingdom which entered into force on 1 April 1929 and gave a full and difinitive understanding to property and considered it as sacred and inviolable. The basis of this code wasthe limited private ownership of which relied on the right to the enjoyment and possessed items without restrictions, being guaranteed and enshrined by law. These would be the first legal acts that will cast the bases of a progressive legal system.1939 marked the end of a long period where Albanian state ceased to exist as a sovereign state.This year was the end of the first conquest of Italy and then Germany, where this period would disperse and would limit a series of rights of political, social, economic that were born and were strengthened before the invasion of the country.

\subsection{The period after 1945.}

During 1945-1990 the Albanian state set a new regime, previously untried, which was formally advertised as a mode of working class and protecting its interests but in reality from the moment it was set up until its overthrow reality spoke to 
Sage, William M. Health Affairs. Jul/Aug2004, Vol. 23 Issue 4, p.10-21. 12p.

Jackson P, Hawker B. 2001. "Is Corporate Social Responsibility Here to Stay?"

R.Mucins "Latvian Treatment Risk Fund: legal aspects". Jurista Vārds (2013 /NR. 41 (792);

Филиппов Ю.Н., Эделев Н.С., Краев И.П., Абаева О.П., 2008;

Latvian Law On the Rights of Patients No 205, dated 17.12.2009;

Latvian Civil Law, date 14.10.1998. 
If a medical practitioner chooses to purchase additional liability insurance, he must reckon with the following:

Insurers in the specific insurance cases often require from medical institution or the medical practitioner to provide more information on the patient, and often the whole case, including the documentation.

Documentation is requested until the trial takes place. However, the Medical Law stipulates that medical practitioners and authorities are not entitled to disclose information about the patient's treatment process until the case has been referred to the court.

It should be noted that private insurance companies do not reimburse to the buyer of insurance, namely the medical practitioner, the costs arising from a trial course.

From the point of view of safeguarding the patients' rights, there is a larger chance to receive compensation for the cases not covered by the Medical Treatment Risk Fund, by raising a civil claim against the medical practitioner. However, in this case the patient should expect the trial process will be much longer and more complicated as the process will include both the patient, the medical practitioner and the insurance company.

The patients are able to influence insurance system quality as well. If patients are active enough and protect their own interests bringing particular cases before the court, they make changes in the system. The insurance companies usually make changes in the costs of insurance for medical professionals. The changes are based on the patients level of activity. ${ }^{14}$

\section{Results}

Authors came to the following results:

1) the rights to protect Latvian medical professionals from the legal liability using professional insurance system are restricted;

2) patients have several legal ways how to claim medical malpractice against medical professional, but there are some restrictions regarding to amount of compensation;

3) there are legal problems according to medical professionals' insurance system quality;

4) the quality of health care system and patients' rights protection depends on how free medical professionals feel.

\section{Conclusion}

Provision of medical personnel professional liability insurance is a huge and important step on the legal relationships between medical personnel professionals and insurance companies. But, it should be noted, that more important point of the medical personnel professional insurance system is social relations created between medical professionals and patients. Medical personnel liability insurance is security not just medical professionals, but for patients as well. The security is multifunctional, from the one hand this security provides to both parties monetary benefits, on the other hand social responsibility.

There are several problems in Latvia regarding patients' possibility claim for compensation in case when medical professionals make mistakes and the patients are harmed due to that claims can be brought. Patients can claim administratively, using Latvian Treatment Risk Fund, or use civil proceedings. Both ways have to be researched deep enough to make final conclusion.

The question about social responsibility comes out. What kind of professional liability insurance is directed to protect patients' rights in the best way. Form the social responsibility contest medical professional have to take into account the best interests of the patients when such disputes arise.

\section{References}

Auerbach, D. I., Brantley, I., Heaton, How Will the Patient Protection and Affordable Care Act Affect Liability Insurance Costs?. Santa Monica, CA: RAND Corporation. P., \& Institute for Civil Justice, (. (U.S.). (2014);

Bovbjerg R.R. and A.Bartow, "Understanding Pennsylvania's Medical Malpractice Crisis: Facts about Liability Insurance, the Legal System, and Health Care in Pennsylvania". Project on Medical Liability in Pennylvania June 2003;

Beauchamp, T. L. and N. E. Bowie, (eds): 2001, Ethical Theory and Business, 6th Edition (Prentice Hall, Upper Saddle River, NJ);

Dyck, Robert G., and Matjaž Mulej. Social Responsibility: Methods, Dilemmas And Hopes. Sharjah, U.A.E.: Bentham Science Publishers, 2014. v, eBook Collection (EBSCOhost).

Sharma J and Bhushan V. Medical. Negligence \& Compensation. 2 nd. Edition. New. Delhi: Bharat Publications; 2004;

${ }^{14}$ Auerbach, D. I., Brantley, I., Heaton, How Will the Patient Protection and Affordable Care Act Affect Liability Insurance Costs?. Santa Monica, CA: RAND Corporation. P., \& Institute for Civil Justice, (. (U.S.). (2014). 
patients to assert their rights, on the other hand, it restricts them from exercising those rights, narrowing the range of patients' rights.

\section{Limitations of Compensation Receival - Lack of State-Required Medical Personnel Insurance}

Establishment of Latvian Medical Treatment Risk Fund gave the patients the opportunity to get compensation for medical personnel damages to the patients' health more quickly. However, there are cases where compensation from the Medical Treatment Risk Fund can not be obtained. For example, low-quality and nonexistent communication from a medical practitioner is not a case of injury or medical risk.

The Directive of March 9, 2011 of European Parliament and the Council no. 2011/24/EU on cross-border patients' rights defines the concept of health damage.

According to the Directive, it involves suffering, injury of physical or mental, illness or death that could have been prevented if at the time the patient came into contact with the health services, he/she had been provided with appropriate and adequate treatment.

This means that, under the Directive, one may apply for the compensation in the case when the damage caused to health could have been prevented. However, due to medical practitioner's action or omission of action, including during the supply of the service, it could not be prevented.

Compensation of Medical Treatment Risk Fund is not paid, if the existence of injury or a causal link between the damage and the action or omission of action of medical personal in the treatment process, is not detected.

At the same time, compensation can not be obtained if damage of organ or tissue, or disorder of anatomical function has relevance to the treatment, but has not been caused by unprofessional conduct of a medical practitioner. ${ }^{12}$

No compensation is available also in the case when the patient with intentional conduct has contributed to the suffered injury, increase of the amount of damage or refused from treatment.

No compensation of from the Medical Treatment Risk Fund is possible for transportation expenses incurred in order to arrive at the medical institution.

\section{Civil Liability Insurance of Medical Personnel}

Regardless of the fact that Medical Treatment Risk Fund is operational in Latvia, medical personnel may still purchase Civil Liability Insurance of Medical Personnel.

However, given the relatively small experience in Latvia in the field of professional liability insurance medical personnel, there are problems with the quality of liability insurance.

There is a practice in Latvia where insurance companies insuring the medical personnel for their civil liability, only reimburse for patients' direct, rather than moral damages. In addition, the proposed risk insurance range is not exhaustive and does not cover the potential risks which may face a medical practitioner. Provided that a medical practitioner wishes to obtain a well-developed civil insurance package, large payments must be paid for the service. Relevant professional liability insurance applied to health professionals is disproportionately expensive, and not always will it cover the risks that can potentially arise.

The private insurer usually pay not more than is strictly required by the law. Latvian Republic Civil Code provides for indirect losses, such as moral damages. Paragraph 2347 of Civil law reads that if a person inflicts a bodily injury upon another person through an action for which he or she is at fault and which is illegal, the first-mentioned person shall compensate the other person for medical treatment expenses and, apart therefrom and pursuant to the discretion of a court, also for potential lost income, and remuneration (material compensation) for moral injury.

The amount of moral demands is decided by the court at its discretion after the individual situation and practice. Admittedly, in the Latvian law practice there are not many cases of non-pecuniary compensation. ${ }^{13}$

Thus, also the attitude of private insurers in the treatment of moral damage compensation for patients is relatively modest and underdeveloped.

12 Cabinet of Ministers Normatives No. 1268 "Regulations on Activities of Medical Treatment Risk Fund". [Online] Available: http://likumi.Iv/doc.php?id=262102 (December 18, 2016)

13 Cabinet of Ministers Normatives No. 1268 "Regulations on Activities of Medical Treatment Risk Fund". [Online] Available: http://likumi.Iv/doc.php?id=262102 (December 18, 2016) 
According to the normative acts governing the Medical Treatment Risk Fund, ${ }^{10}$ the budget of Medical Treatment Risk Fund is replenished by both state and private medical institutions. Its amount is calculated yearly by the National Health Service by taking into account the employees of the relevant institutions, medical personnel, and the number of persons belonging to certain risk groups. On basis of such a system, a fund is established funds from which payments are carried out in case there are damages to patient's life or health.

Establishment of the aforementioned fund has also served as the reason to adopt amendments in the „Act on Practicioning Doctors", which were devised in accordance with what is determined in the Act on Patients' Rights about the Medical Treatment Risk Fund.

Until the establishment of Medical Treatment Risk Fund, the rights of patients to receive compensation for damage to life or health caused by medical personnel were relatively limited. The patient had the rights to take legal action against a medical practitioner or institution under the civil procedure. This means that the patient had to have financial means to submit the application to the court, as well as the means to get legal assistance in preparing the court application. In addition to that, the trial under the Latvian civil procedure can take up relatively long periods - up to 5-7 years. In international practice claims involving relative similar injuries usually take more than 5 years as well to be resolved. ${ }^{11}$

After creation of Medical Treatment Risk Fund, patients were given the opportunity to address the issue of damages to health or life suffered during health care under the administrative procedure.

Compensation may be obtained for damages incurred to patient's life or health in the treatment process, as well as for expenses associated with treatment to prevent or reduce adverse effects caused by the damages.

In accordance with Paragraph 16, part I of the Latvian Act on Patient's Rights, the patient has the rights to compensation for the damages incurred to his life or health (including moral damages), which by their action or inaction are caused by medical practitioners in a medical institution, or caused by the circumstances during treatment, as well as the rights to be reimbursed for expenses related to medical treatment, if such a treatment was necessary to prevent or alleviate adverse effects by a medical practitioner or medical conditions at the time of damage to the patient's life or health.

Paragraph 16, Part II of the Latvian Act on Patient's Rights stipulates that persons may receive compensation from the Medical Treatment Risk Fund in the following amounts:

1. for the damage incurred to his life or health (including moral damages) - in the amount of damage, but not more than EUR 142,290;

2. for the medical expenses caused to the patient - in the amount of the expenses, but not more than EUR 28,460 .

Unlike the cases of patient damages dealt with under the civil procedure, cases within the Medical Treatment Risk Fund about compensation for the damages to patient's life and health, and compensations for the patient's medical expenses, are assessed, and a decision is taken in six months from the date of application. In this case the examination period is many times shorter than under the civil procedure. Length of proceedings, if necessary, can be extended up to one year. However, it is only on the condition that the institution needs to request, collect and assess additional information in order to review the compensation claim and take a decision.

When examining the patient's complaint under the administrative procedure, the patient claims the compensation for damages to his life or health, as well as compensation for the medical expenses from the Medical Treatment Risk Fund no later than two years from discovering of the injury, but no later than three years from it occurred. This provision significantly restricts the patients' rights, unlike if the case was reviewed under the civil procedure.

An important aspect is the fact that according to Paragraph 16. Part II of Act on Patients' Rights, the compensations are not reimbursed if the patient has already received compensation for the damage to his life or health or for the medical expenses has already been received under a civil or criminal proceeding.

Another important aspect is that the patient is entitled to compensation for the damages incurred to his health irrespectively of whether the health service was received in a state, local communal or private medical institution.

On the bases of the aforementioned, it should be noted that the Fund significantly facilitates the possibilities for

10 Cabinet of Ministers Normatives No. 1268 "Regulations on Activities of Medical Treatment Risk Fund". [Online] Available: http://likumi.Iv/doc.php?id=262102 (December 18, 2016)

${ }^{11}$ R.R. Bovbjerg and A.Bartow, "Understanding Pennsylvania's Medical Malpractice Crisis: Facts about Liability, 2003 Insurance, the Legal System, and Health Care in Pennsylvania". Project on Medical Liability in Pennylvania June 2003 [Online] Available: http://www.urban.org/sites/default/files/alfresco/publication-pdfs/1000732-Understanding-Pennsylvania-s-Medical-Malpractice-Crisis.PDF (December 10, 2016) 
decision.

Medical practitioner, in the very essence of his or her deeds, carries out public functions, which are based on socially responsible behavior.

The concept of social responsibility is vast. But at the same time there are lack of definition of social responsibility. ${ }^{4}$

Author Dyck, Robert G. states that social responsibility is positive live concept 'everyone's impacts everyone. At the same time author explains, that social responsibility is one's responsibility for one's impacts on society, meaning other humans and their organizations, rather than one-self only. ${ }^{5}$

The authors assert that one of the definitions of social responsibility pinpoints that it is the range of parties' obligations to exert necessary support for the society. Social responsibility is in a way ethical conduct that is focused on the relevant group of persons or towards the general public.

According to Paragraph 1 of the Code of Ethics of Latvian Doctor Association, fundamental principle of a doctor's activities is a of respect for human life, humanity and individual human rights, irrespective of person's nationality, race, religion, age, sex, political opinion and social status. Along with the rest of the community, a physician is responsible for the health of general public, its improvements and an equitable health care system. It should be noted the mentioned aspect directly points to the behavior of medical personnel - to defend the public interests.

Code of Ethics of Latvian Doctor Association has been based on the International Code of Ethics which in year 1993 was developed and confirmed by the Global Medical Association. Therefore, a similar interpretation of medical practitioners' social responsibility is also adopted internationally.

Actions of medical personnel an effect each individual. That is exactly why the medical personnel, upon choosing the professional liability insurance model for a person, should remember the institute of social responsibility. Medical practitioners cannot be fully protected against their possibly unintentional errors in the treatment process. Neither is the patient immune to doctor's errors. This also means that the doctor must be ensured that a patient harmed due to his fault is getting compensated in the highest quality and most efficient way. ${ }^{6}$

\section{Insurance of Medical Personnel in Latvia}

The liability insurance system itself has been spared serious analysis from a health policy perspective. The politics of liability insurance has been dominated by the offspring of the crisis of the 1970s. The system still exists because of transformation processes particular in professional liability. ${ }^{7}$

None of the medical practitioners are protected against accidents or mistakes. There is no doubt that each patient's clinical course is highly individual, so the treatment process is always associated with some degree of risk. As per statistical data of World Health Organization, medical errors take place in 8-12\% of hospitalization cases in countries of European Union. ${ }^{8}$

In 2013, amendments to the Act „On Practicioning Doctors” entered into legal force. These excluded the paragraph that requested the medical personnel to acquire mandatory third party liability insurance. So far, medical personnel had to take double occupational insurances. This was mandated by the Latvian Patient Rights Act. However, a Medical Treatment Risk Fund started operation on October 25, 2013. The established institution aims to provide an out-of-court opportunity for patients to reimburse for the damages incurred to patient's life or health during the process of health care.

That mentioned idea was taken over from the Scandinavian countries. Thus, the Latvian Parliament voted for creation of a state administered fund - Medical Treatment Risk Fund.

Medical Treatment Risk Fund is established in the national insurance scheme against the risks in the medical sector that provides medical personnel the opportunity to protect them from consequences possible from their professional activities. ${ }^{9}$

\footnotetext{
${ }^{4}$ Jackson P, Hawker B. 2001. Is Corporate Social Responsibility Here to Stay? http://kantakji.com/media/3452/z113.pdf (December 2016)

${ }^{5}$ Dyck, Robert G., and Matjaž Mulej. Social Responsibility : Methods, Dilemmas And Hopes. Sharjah, U.A.E.: Bentham Science Publishers, 2014. v, eBook Collection (EBSCOhost). Web. 19 Dec. 2016.

${ }^{6}$ Beauchamp, T. L. and N. E. Bowie, (eds): 2001, Ethical Theory and Business, 6th Edition (Prentice Hall, Upper Saddle River, NJ).

${ }^{7}$ Sage, William M. Health Affairs. Jul/Aug2004, Vol. 23 Issue 4, p10-21. 12p.

8 World Healt organization. Data and Statistics [Online] Available http://www.euro.who.int/en/health-topics/Health-systems/patientsafety/data-and-statistics ( December 16, 2016)

${ }^{9}$ R.Mucins "Latvian Treatment Risk Fund: legal aspects". Jurista Vārds (2013 /NR. 41 (792);
} 
Medical professionals have to act in the best interests of patients and protect the constitutional rights of each individual patient. But what happens when medical professionals make mistakes? Are they protected enough? Medical professionals work with the main aim to deliver good quality healthcare. In case when they do make a mistake and a patient gets harmed because of this mistake, it is important that medical professionals have insurance or indemnity. It should be noted, that patients' rights and possibilities to compensate for the damage depend on how good, and what quality, the insurance of medical professionals' liability, or indemnity, is.

Poor quality of work from the side of medical professionals is a restriction of patient's fundamental rights. Medical professional's mistake is their ethics, prestige and social responsibility issue before the patients'.

Medical professionals are not protected from patients' reactions. A patient can file a medical malpractice claim against a medical professional at any moment. It should be noted that in today's medical negligence claims and mistakes are increasing. The progress of medical law shows that patients use the rights and legal options to protect their interests more and more.

More and more often patients' claims include requests regarding moral compensations accusing medical professionals of having caused them injury, or of not having provided necessary medical services. Also, contractual terms and conditions are usually requested by patients in the private sector. Patients have information regarding minimum health care standards and use the opportunity to protect their best interests.

In order to protect medical professionals, a professional medical insurance system is used, which covers healthcare practice and provides professional protection against financial consequences of legal liability. ${ }^{3}$

\subsection{Objective of the work and methods}

The objective of the work is to present a summary of the system of professional medical insurance in Latvia. The paper discusses the legal mechanisms to be improved, and deals with how the professional medical insurance system, as well as patients' rights to receive compensation, could be optimized.

The paper utilized descriptive, analytical and deduction-induction methods. Within these methods, legal acts are analyzed, opinions of legal scientists are recorded, and conclusions are drawn and suggestions made.

\subsection{Analyses}

National acts that regulate insurance system of medical personnel professional liability, are in force in Latvia.

In 2013, the Latvian Medical Treatment Risk Fund was established. The aim of the found is to provide opportunities for the patients to protect their rights and receive help outside of the court.

For medical professionals, it is an opportunity to protect themselves against the risks related to their professional activity and its possible consequences.

Financial resources are paid into the Medical Treatment Risk Fund by medical institutions. In addition to that, a research by Latvian insurance companies who provide professional civil liability insurance for doctors, was carried out.

Additionally, a medical practitioner may purchase a professional risk insurance of his or her civil liability. In this case, a medical practitioner will be able to protect him/herself by expanding the range of services offered by the insurer and the associated insurance packages, yet in this case one would have to reckon with the high levels of cost of such insurance.

\section{Legal and Social Responsibility of Medical Personnel}

During the research of relationship of medical personnel and patients that emerge from the parties' disputes concerning treatment process or damage incurred to patient's life health, one has to conclude that the chosen type of insurance by the medical professional has an important role in safeguarding patient's rights.

Depending on what type of professional risks the medical personnel covers, the patient has, or has not, rights to receive compensation for such aspects as, e.g., damages caused to his or her health during the treatment process.

This means that there must be balance between rights and responsibilities of medical personnel and patients. In order to create this balance, each of the parties must be aware of the importance of social responsibility by taking any 


\title{
Insurance of Medical Personnel Professional Responsibility as a Form of Legal and Social Responsibility
}

\author{
Dr.iur. Inga Kudeikina \\ Riga Stradins University, Faculty of Law, Latvia \\ Email: Inga.Kudeikina@rsu.Iv \\ Mg.iur. Karina Palkova \\ Riga Stradins University, Doctoral Department, Latvia \\ Email: Karina.Palkova@inbox.Iv
}

\section{Doi:10.5901/ajis.2016.v5n3s1p320}

\section{Abstract}

\begin{abstract}
Medical professionals are not protected from patients' action in the case of medical negligence or mistake. Anytime patient can file a medical malpractice claim against medical professional. Nowadays medical negligence claims and mistakes are increasing. The progress of medical law shows, that patients more often use the rights and legal options to protect their interests and fundamental rights. The scope of the freedom of medical professionals is limited. They have to act in accordance with certain standards or an artificially created frame and in the best interests of their patients and protect constitutional rights of each patient. In case when medical professionals make mistakes and the patients are harmed due to that claims can be brought. Medical professionals must have insurance or indemnity to protect themselves, but patients also need it. Patients' rights and possibility to compensate damage depends on how good and qualitative the medical professional liability insurance or indemnity is. Furthermore, medical professional's mistake is his or her own ethical, prestige and social responsibility in front of the patients' issue. In order to protect medical professionals and patients the medical professional insurance system has to cover healthcare practice and provide professional protection against the financial consequences of legal liability, as well as possible moral compensation. The objective of the paper is to present a summary of medical professional insurance system in Latvia. The article will provide information about what legal mechanisms shall be improved in order to optimize medical professionals' insurance system and patients' rights to receive compensation.
\end{abstract}

Keywords: medical professionals, professional liability insurance, patients

\section{Introduction}

An increasingly frequent opinion is highlighted that the level of public health depends on the available health care and health care quality. One of the prerequisites of the high-quality of received health care is patient's satisfaction with the services received and his state of health after them. In this case, attention is also paid to the fact whether the patient is satisfied with the assigned and safeguarded rights from the side of medical personnel and the quality of communication in general. ${ }^{1}$

The social aspect in the relationship between medical personnel and the patient is gradually becoming an important form of social relationship. It directly affects both of the following aspects: the patient's rights and desire to receive access to quality services, and medical practitioners' need to expand the boundaries of social activities to meet the legal interests of their patients.

However, there is a problem within the scope of activities of medical professionals. The independence of medical professionals is relative. The scope of the freedom of medical professionals is limited and does not give the rights to medical professionals to act freely. The persons have to act in accordance with certain standards or an artificially created frame. ${ }^{2}$

\footnotetext{
1 Филиппов Ю.Н., Эделев Н.С., Краев И.П., Абаева О.П., 2008

2 http://ejms.euser.org/index.php/all-volumes-ejms/january-april-2016-nr-2/387-issues-of-legal-organization-of-the-patient-health-careprofessional-relationship
} 
Haxhiaj, Floresha. (1978) "Andon Zako Çajupi Poezi", Parathënie, "Naim Frashëri", Tiranë.

Haxhiaj, Floresha. (1073) "Motivet sociale në krijimtarinë letrare të A.Z. Çajupit", Studime Filologjike II, Tiranë.

Islamaj, Shefkije. (2008) "Gjuha dhe identiteti", Tiranë.

Kastrati, Jup. (1956) Parathënie, "Poezi shqipe të shekullit XV", Kangë të Milosaut bir i sundimtarit të Shkodrës, Tiranë.

Kodra, Klara. (1981) "Poemat e De Radës", Studime për letërsinë shqiptare I, Tiranë.

Prifti, Stefan. (1966) "Elipsa në sintaksën shqipe", Studime Filologjike III, Tiranë.

Qosja, Rexhep. (1979) "Kulti i së shkuarës në letërsinë e Rilindjes", Studime filologjike I, Tiranë.

Resuli, Namik.(2007) "Shkrimtarët shqiptarë nga Buzuku te arbëreshët e Greqisë", "PAKTI".

Shuteriqi, Dhimitër. (1973) "Nëpër shekujt letrarë", Në 150-vjetorin e lindjes së Jeronim De Radës, Tiranë.

Shuteriqi, Dhimitër. (1974) Lavdia e De Radës, Gjurmime letrare, Tiranë.

Shapllo, Dalan. (1970) "Disa tipare të romantizmit në letërsinë shqipe të Rilindjes Kombëtare", Studime filologjike IV, Tiranë.

Thomai, Jani. (2006) "Leksikologjia e gjuhës shqipe",Tiranë.

Xhaxhiu, Myzafer. (1981) A.Z.Çajupi-poet i shquar dhe mendimtar i Rilindjes sonë kombëtare, Shkrimtarë, vepra dhe dukuri letrare, Tiranë. 
Even at Çajupi, the compositions are folk formations with a high emotional nuance and with a high expressivity. For example: dorështrënguar, mustaqemath, meshollë, syzezë, gushëbardhë, kokëshinik, rrënjëdalë, mendjeprishur, zemërlig, zemërmirë, qimeverdhë etc.

Generally, Çajupi's compositions are formed from noun + adjective, such as: dorë+ e shtrënguar, mes+ $i$ hollë, sy+ e zezë, gushë+ e bardhë, zemër+ e ligë, punë+ e bardhë etc., where the second part determines the first. But there are even compositions which are formed from noun + noun, such as: kokë+ derr, kokë+shinik, zemër+ trim etc.

But even the formations through compositions were exploited by the poets to express the literary, artistic, esthetic ideas.

At De Rada, we can find formations:

With a prefix: pa-: e pafajme, i pakrypi, e pakujdesje, e pamëshirtë; për-: përbalti, të përhedhurat, përtrualli, përthan, përhodh, përshkit, përqafje, përthelluar, u përjoshën, përdorez; stër-: stërkrekosur,

With a suffix: -ake: fluturake; -ësi: mburrësi; -ëri: brishtëri; -ore: qiellore, kreshtërore, kallëzore, pengore, dritësore, gjelbërore; -lluan: zbardhëlluan; -llore: verdhëllore, bardhëllore; -ëz:vashëz, shenjëzën; -on:fushullon, hijeshon; -rimë: zhurmërimë; -ruar: e gjetheruar; -shëm: tronditshëm; -tar: djegtar, ndihmëtar, shëndetare, rrezetar, grënjëtar; -tore: zhurmëtore; -tur: lagështitur; -ëthin: zverkëthin, gërshetëthin; -th: qirith; -thi: djepthi, djalthi, ngatërrimthi; -uan: zbardhuan, zymtuan;

The adverbs were also used extensively in the lines of the authors of the period of Renaissance. They might be simple, with compositions, etc. the adverb with the suffix -(i)sht is identified in De Rada's language. For example: dhembshurisht, lirisht, krenarisht, zymtësisht, bindurisht etj. They are of different kinds: Way: mir(ë), bukur, lir(ë), rënd(ë), leht(ë), trash(ë), rrall(ë) etc.,; adverbs formed from the unification of a group of words ae.g.: përtrolli, menatë; the adverbs which are not found anywhere in the spoken discourses, in the written documents in Albanian, etc., with the suffix thi:qirithi; the adverbs formed from the repetition of the same word: vende-vende, copa-copa, besa-besë, rreshta-rreshta etc. Adverbs of quantity: pak, shum(ë), një cik(ë) etc.; Place: jasht(ë), këtej, këtu, atje, afër, përpara, prapa, kudo, posht(ë), matanë etc.; Time: sot, nesër, dje, parzën, mbrëmanet etc.

Poetry was the most elaborated and developed literary genre in the period of Renaissance. The poetic discourse of De Rada and Çajupi at that time give evidence of a rich language full of expressive means and stylistic figures. However, at De Rada there are some attempts to be consequent with the development and the improvement of the language in order to have a wide influence on the people.

Reading De Rada in the Arbëresh language, the people would get enriched spiritually and such characters such as Milosao, Serafina, Scanderbeg would serve as models of inspiration which would nourish their ethnical awareness, the love for the country, which was even the greatest mission of De Rada. This pioneer of the laic Albanian poetry of romanticism, reached the conclusion that under the hard conditions of Albania, which was conquered, the Albanian people did not have the opportunity to develop its own language and literature. So, it was the duty of the Arbëresh settlements in Italy to create a standard language and to transmit it to the home-country ${ }^{10}$. He was a man of Renaissance and the Albanian Renaissance would unify the political ideals of the citizens of the period of Renaissance and the human ideals of the resurrection of man. The nation resurrection and its freedom, in the thoughts of De Rada and Çajupi, is connected with the resurrection of man and his freedom, with his mind and spiritual enrichment, with his moral perfection. In this viewpoint, the lyrical perspectives of De Rada and Çajupi, expressed at "Këngët e Milosaos" and the poems of "Baba Tomorri" intend to mirror a new world of human feelings, the aspirations of the poets for emancipation and the acceptance of the individuality of their personality.

These motives were brought to the Albanian poetry the innovation and the artistic richness which had been not known before. De Rada and Çajupi remain the classical examples of the poets who expressed the spirit of the people through a simple and direct language, but which still remains expressive and fresh.

\section{References}

Bulo, Jorgo. (1991) "Andon Zako Çajupi", Studime Filologjike I, Tiranë.

Bulo, Jorgo. (1966) "Rreth ndikimit të folklorit në veprën e Çajupit", Studime Filologjike II, Tiranë.

Çajupi, Andon. (1902) "Pjesë të zgjedhura", Parathënie, Kairo.

Çajupi, Andon. (1957) Vepra, Tiranë.

10 Kostallari, Androkli, Studime Filolofjike III, Rreth një pikëpamje të Jeronim de Radës për formimin e gjuhës letrare të kombit shqiptar, Tiranë, 1981, p. 3. 
pronoun unë. For example: nga u ç'të ligë ke parë?; hëngra dhe u mish njeriu; or the incomplete form of the verb qan, of the nouns revole, telefon etc., for example.: ç'ke që qa prapë taninë?; nga një revol!; mund të na vijë një tel; or the reduction of the consonant $j$ such as in the examples: mbai për vete, vi rrotull etj.

The phonological reduction is a consequence of the linguistic economizing which is more spread in the conversational discourse and then it was taken even to the poetic language ${ }^{8}$. Due to the use of the ellipse several times, De Rada's language resulted to be difficult and not natural. Tommaseu explain that the ellipse, this syntax figure, is necessary in poetry. Even in De Rada's poems, its use has become a style-formation feature of the author. For example: Mendja tretur në ç'kish shkuar; Gjaku im te Lumi i Vodhit; Po tani të gjitha ëndrra!; Sa hie në ato zakone!

The beautiful and strong feeling of love provides the same force to the heroes to face the life-or-death wars and the poets have chosen the express it through the figures of the rhythms and sounds delicately. Here are some lines where the poetic explosions of Çajupi are expressed through the exclamation: O qipariz bujarësh! O $i$ bardhë bir bujari! 0 vasha kryegështenjë! Ditët e mia fatmira! The joy and the pain caused by love are expressed through direct intonation calls, which are caused due to the serious state where Albania is. In some other cases, the author expresses the concern about the youngsters who are leaving. For example: 0 moj Shqipëri e mjerë?; O pëllumb i shkruar!; 0 moj portë, moj e shkretë/Mos rri mbyllurë përjetë!; O kaur o këthatë!; O korrik, o faqezjarr!; O ju të ra dhe të ril; Obobo e ububu/Mikia ndër mënd u vu/Në shtëpi të saj më shpu...etj.

The exclamations are of different kinds: a) simple, 0 , $a$, oh, ah, etc; b) derivatives of simple words (with conversion from different parts of the speech): o burra, e zeza, lum, etc.

Very often, the inner world of the poet or the emotional and psychological states are emphasized through the figures which derive from the repetitions, such as anaphora, e.g.:. Bëre pemëtë me fletë/Bëre dimër e beharë/Bëre arinë dhe denë; Qani pyje, fusha, gurë/Qani male me dëborë! Me zë të madh si shkëmbi/Me zë të madh si gjëmimi etc. ; epanalepsis, e.g.:. Mbeta more shokë mbeta; Kurbeti shokë kurbeti; Duro, varfëri duro; U tretë, Gjon Lek', u tretë!; Bariu, shokë bariu etc.

The ideology of Renaissance was expressed through a synthetic poetic art where the poets wanted to give a lot through just a few elements, they wanted to make big figurative generalizations, etc. So it was a kind of art which mostly suggested rather than showed. For example: the concise style of De Rada did not accept the overloads and the exaggerations. It was distinguished for a normal figuration, without the exaggerated decorations and the fantasy. With an artistic intuition, simplicity and sincerity, he created beautiful epithets such as: valët kreshtërore, hadhia vilebardhë, vasha mespurtekë, re e ufme etj.

Furthermore, the irregular syntax assists the function of the idea in the lines written by the poets of this period. So in the lines the figure of inversion is very prominent. It emphasizes the qualities of the objects or the spiritual states of the characters in the poems of De Rada and Çajupi, such as: Rina, Milosao, Serafina, etc. In the lines of "Milosao", we find: e bardha shtëpia ime, me të lodhurat të bijat, të erëkëndshmen kafe pinte, një të hirshme zanë,të zbehtat faqe ia kam soditë, të hirshmet dhoma, të hajthmen dorë i putha, me një të trembur hare, me të nderëm bij bujarësh, me të bardhë cipë kreit, dheut huaj ahere ndër time motra kisha arritur etc.

The poetic lexics of Renaissance is rich even with composed words. It has been proved that composition in Albanian constitutes a very developed and folk type ${ }^{9}$. We find these features at De Rada in the function of an epithet. For example:

The formations noun + past participle:

gjifryrë, fatgëzuar, flokëthinjur, këmbëngjyer, ballukepërpushur, tehpërgjakur, kokëprerë, vështrimfyer, vështrimmekur, gjakmbytur, ballëvrejtur etc.;

The formations noun + noun:

syulli, mespurtekë,kryegështënjëzë,majëhekur, kryepluhurosurën, ëngjëllroja, hijezie, majëakull, qumështkrua, mendjemuzg, syflakë, flladpasosje etc.;

The formations noun + adjective:

ballëgjerë, flokëbardhë, buzëhieshmen, mendimqetë, shpirtbujar, ballëzbehtë, gojëhapët, pamjebardhë, orëbardhë, lëkurëshkretë, vilebardhë etc.;

The formations noun + adverb:

zakonbukur, drekëherë, nderplot, lotçurgë etc.

${ }^{8}$ Islamaj, Shefkije, "Gjuha dhe identiteti", TOENA, Tiranë, 2008, p. 257.

${ }^{9}$ Thomai, Jani, "Leksikologjia e gjuhës shqipe", TOENA, Tiranë, 2006, p. 182. 
figure is used to express another state, the poet's concern for the fate of his own country which is threatened by the conquerors. This is how he expresses his ideas at song V of "Milosao": Përse të venë në det/ mendimet zemëra ime?/Zbardhuan anijëzat/Pranë këndej e u fshehën...

The poets expressed their prosperous spiritual world, the characters' nature or state through beautiful nominal or verbal metaphors, powerful stylistic means which made these works unrepeatable. Among the lines of "Milosao" and "Serafina" we find the metaphors: nata e zezë, zemrat u drodhën, fytyrat u errën, shiu i butë, mbiu një re manushaqesh, pranverë e bardhë, gjetkë mbytej mendja e saj, dielli i ra te shtrati, m'i këputi gjumin, m'u errësua jeta, flakë iu ndez fytyra trimit etc. Meanwhile at "Baba Tomorri" from Çajupi the following metaphors are distinguished: fluturon dashuria, ma paske gjuhën bilbil, zemra bëhet behar, zemëra jote u bë gur për mua etc.

The breathtaking Albanian nature, and particularly the countryside lifestyle with all its nature wonders, along with the problems and the concerns of the people who live there, will get the right position in the poetry productions of the authors of Renaissance. Çajupi is equally the sweet poet of the countryside as well as the poet of the city ${ }^{5}$. The opinions and the feelings of the poet will be compared in details from this wonderful nature. For example: shket si ngjalë, nusia si zog deti, faqekuqe si një shegë, koka më digjet si furrë, të ëmbël si shqerrë, zë si shpellë, paske trutë si hirrë, si një zog në kafaz, si burim i venë lotë, si sokadhe, si mollë e pabërë etc. This figure of speech is highly used even by De Rada. The poet constructs the figure of comparison with elements from the Albanian Arbëresh nature, which provide the lines with a special beauty and power of expression. For example: si ato lule qielli, si thëllëza te foleja, posi valë, si një flutur përmbi ujët, si suvala e detit, si drita në qiell e syu në kurm të fëmiut, porsi shqerrat në livadhe, si dallgë deti etc. Among the lines, the similitude or the extended comparison are also encountered very often. For example: Një hare më rodhi kurmit /si hareja kur te shtrati, mbrëmanet /vajza e ngrohtë ndien për të parëzën sisët që m’i fryhen; Duro zemër duro si duron mali me borë.

Çajupi treated even the love and social motives with e fine poetic sensation in some of the best poems of "Baba Tomorri". The beauty of the dear girl, the feelings of the lyrical hero, which are very concrete and human are often compared with the most beautiful elements of nature. These lyrics are nice and have communicative power even today. For example: Leshërat e tua posi pendë korbi/Ballëtë si diell, faqetë si mollë/Sisetë si shegë, dhëmbët si thëlpënjë/Buzët si burbuqe, sytë si gështenjë/Dora si dëborë, fjala jote mjaltë. The extended comparison which is spread in more than one line in Çajupi's poetry has sublimed this feeling which enriches the resurrected indivisual of this time. For example: $\mathrm{Si}$ dallëndyshja vete në vend tjetër/Dhe kthehetë prapë në fole të vjetër/Ashtu zemra jote mundet të kujtojë/Mikn'e djalërisë dhe prapë të dojë...

The social issues which were treated in the poetry of the period of Renaissance commence with the enslaved condition of the Albanian woman, to migration as a hurting wound of that time, to the detection of the contrast between the wealth and the poverty, etc 6 . In order to mirror the appropriately in his poetry, Çajupi uses in his poetry words of opposite meaning, antonyms. For example: zhvish-vish, lerë-vdesëm, pleqtë-të ritë, i zi-i bardhë, të pasur-të varfër, korrmbjell, dit'-nat' etc., which serve even for the construction of the antithesis and contrast providing his most powerful lyrical discourse. For example: Zhvish rrobat e robërisë mëmëdhe/Vish armët e trimërisë se ke ne!; Kemi lerë e do të vdesëm; Të rrojnë pleqtë/Të vdesin të ritë; Kasap i zi/ me zemër të bardhë; S’kish të pasur e të varfër; Kur të korr e kur të mbjell; Turpëronem dit' e nat'; Moj mike kush të gënjeul Dhe të shiti a të bleu?

Studying the language of the Renaissance poets it is noticed that they have a special feature, the feeling of the measure; in their lines ellipse is provided giving liveliness and grace. Çajupi writes: Malet me gurë,/fushat me bar shumë,/arat me grurë, më tutje një lumë.; Pika-pika bie shiu/dhe dëbora flokë-flokë,/vetëtin e fryn veriu,/breshëri kërcet mbi tokë; Mor zot, pse dëm fjalët? etj.

The phenomenon of ellipse is natural, or normal for the language, determined from different subjective or objective reasons. Therefore, it cannot always be related to the grade of self-awareness, because the language and the opinion realized in one subject have even an objective existence ${ }^{7}$. As the people say "to cut the long way short", even our poet leaves aside either consciously or unconsciously what can be implied. Therefore, we do not consider this as the poverty of the Çajupi's style, but as a phenomenon which is created due to an economic principle which everything not essential for the thought is left aside.

An elliptic form is even the structure $u$ encountered in the lines, the reduction of the full form of the personal

\footnotetext{
5 Bulo, Jorgo, "Andon Zako Çajupi", Studime Filologjike I, Tiranë 1991, p. 110.

${ }^{6}$ Haxhiaj, Floresha, "Andon Zako Çajupi Poezi”, Parathënie, "Naim Frashëri”, Tiranë, 1978, p. 9

${ }^{7}$ Prifti, Stefan, "Elipsa në sintaksën shqipe", Studime Filologjike III, Tiranë, 1966, p. 133.
} 
the Arbëresh dialect to the level of a standard language, even though this care damaged his work considerably, because time after time he suppressed the feeling and the inspiration, along with the simplicity and the spontaneity. Meanwhile, De Rada accepted that his style became difficult. ${ }^{1}$

"Këngët e Milosaos" one of the poet's most beautiful creations, is characterized with an internal equilibrium between the content and structure. ${ }^{2}$ Also, the lines of "Serafina", "Scanderbeg", through the rhythms which in some cases were impulsive and sometimes peaceful, touch us even today with the power of their feeling. With these masterpieces, De Rada was confirmed as a powerful and special voice in the Albanian literature of Renaissance.

The love for the home-country, the responsibility and the obligation to fight for the liberation of the country, the unification of the Albanian people leaving aside the conflicts and the disunion, are some of the major ideas of the time. A considerable obstacle in the way of politic unity was the religious disunion kept alive and encouraged by the ottoman conquerors and the chauvinist circles of the neighbouring countries. But "the Albanian is Albanian before he is a Muslim or an orthodox" - the poets accepted powerfully in their lines raising the idea of the nationality above the idea of religion.

In the patriotic lyrics of the volume "Baba Tomorri" ("Father Tomorri"), Çajupi would express exquisitely the love for the home-country, the persistent war of the Albanians to get liberated from the foreign suppression, through the hyperbole. For example: Treqind lebër qimeverdhë/Te Gryk'e Kuçit u derdhë; Trimërinë s'ia nxë dheu!; Po thërret sa tundet vendi etc.

Within the lyrics of this poet we will find even the ironic opinion towards the old-fashioned traditions, towards religion and God, when he constructs such questions which do not get an answer. For example: Pse u bë nga Perëndija?/Mirësia, ligësia/Që të vuaj njerëzia/Gjithë këto të këqia?

The lyrical poetry of Renaissance, particularly Çajupi's poetry brought to Albanian literature the spiritual world of the individual, the dramas of his life, a world in a turbulent movement, the spirit woken up from the medieval sleep which would numb the human mind. The sadness and the deep pain for the people, who would bear all the burden of the social injustice, is felt in every line of the poetry of that time. For example: Oh, të zestë punëtorë!/duke punuar qanin/se sa me kamçik në dorë/i qërtonin e i rrahnin. Dhe mos i godisnin pak!/bobo arapët e mjerë!/i rrahnin sa u del gjak/dhe sa vdisnin ca të tjerë.

An important feature of Renaissance culture and literature is the revitalization and reappreciation of the traditional values of the Albanian culture, particularly its close relation with the domestic folklore, the reemployment of the poetic motifs and forms of the oral popular productions.

The poetry of Renaissance was significantly influenced by the folk poetry. Çajupi's work mirrored the problems and the concerns of the people, its dreams and spirit, with a simple, understandable language for them ${ }^{3}$. The popular trend became a creative principle which is felt in all the works of the poet. The popular lexis and phraseology gave finesse, simplicity and sincerity to the expression of the feelings and to Çajupi's thoughts as well. The words and the expressions from the popular lexis, such as: sos, kuvendoj, qas, të piqemi, më të mëngjër, kandiset, fiqiri, qederi, sëra, ca petka vëravëra, të vdeç, të lëvdonjë, gjegja, etc. have gained poetic value in the lines of the poet, and demonstrate clearly his relation to the popular tradition. For example: Mike pse më prish fiqirë/përvëlon si zjarri?

The clarity, the simplicity of the phrase, the rich linguistic and stylistic figuration are special features found in the language of the people. These features involved in the respective language, according to Çajupi, had to be accepted through written works. Pursuing this way, Çajupi brought an invaluable contribution for the enrichment of Albanian language with the rich folk phraseology, with active and new phrases ${ }^{4}$. The idiomatic units provide the line with emotional nuances, and simultaneously reflect the poet's position. Some examples are: bëj këmbët bigë; këput qafën; lë shëndenë!; si buka që ha; heq shpirt; nuk kërren asnjë fjalë; fjalët i merr era; si dy e dy bëjnë katër; u pjell mendja; s'më dërsin veshi për botë; nga hunda s'më heq dot kurrë; u hante koka për brirë etj.

Apart from the influence from the folk poetry, De Rada was influenced even from the romantic poetry; therefore the lines at "Milosao", "Serafina" and "Scanderbeg" bear a wide figuration which is highly expressive. Such is the metaphor of the first lines of "Milosao": Bota kish ndërruar lisa/Uji i ri n'det kaltëronte n'ditn e re, etc. These lines transmit the idea of the revival of nature in spring, which implies the resurrection of man and of his poetic spirit. Furthermore, in this song, this

\footnotetext{
1 Shuteriqi, Dhimitër, 'Nëpër shekujt letrarë”, Në 150-vjetorin e lindjes së Jeronim De Radës (Through the literary centuries, On the 150th anniversary of Jeronim De Rada's Birthday), "Naim Frashëri”, Tirana, 1973, p. 158.

2 Kodra, Klara, "Studime për letërsinë shqiptare I" ("Studies on Albanian Literature"), De Rada's poems, Tirana, 1981, p. 196.

3 Xhaxhiu, Myzafer, "Shkrimtarë, vepra dhe dukuri letrare", A.Z.Çajupi-poet i shquar dhe mendimtar i Rilindjes sonë kombëtare, Tiranë, Shtypshkronja e Re, 1981, p. 28.

${ }^{4}$ Bulo, Jorgo, "Rreth ndikimit të folklorit në veprën e Çajupit", Studime Filologjike II, Tiranë 1966, p. 109.
} 


\title{
The Language of Albanian Renaissance Poetry: A Reflection of National Ideals
}

\section{Greta Jani}

\author{
Email: greta_jani@yahoo.com
}

\section{Doi:10.5901/ajis.2016.v5n3s1p314}

\begin{abstract}
The Albanian Renaissance is characterized by the development of a new ideology and culture under the influence of national enlightenment and democracy. The present paper aims to highlight the features of lexicon, style and word-formation in the poetry of the time. The paper focuses on the poetic works of two Albanian Renaissance writers: De Rada and Çajupi. Their poetic discourse gives evidence of a rich language full of expressive means and stylistic devices. The two poets, considered as pioneers of the laic poetry, concluded that because of the Turkish occupation the Albanian people did not have the opportunity to develop its own language and literature. According to De Rada and Çajupi the nation resurrection is connected with the resurrection of man, while its freedom with man's mind, spiritual enrichment and moral perfection. In this viewpoint, the lyrical perspectives of De Rada and Çajupi expressed in their poems intend to mirror a new world of human feelings, the aspirations of the poets for emancipation and their poetic individuality and unique personality. These motives brought to Albanian poetry an innovation and artistic richness that had not been known before. De Rada and Çajupi are the classical examples of the poets who expressed the spirit of the people through a simple and direct language which remains expressive and fresh despite the passing of time.
\end{abstract}

Keywords: language, lexical, stylistic, word-formation, poetry

The development of Albanian language was an important issue for the Albanian nation. "The sign of nationality is language, every nation exists because of it," said Sami Frashëri. When a nation loses its language, it loses its identity. Our nation not only survived in the course of centuries, but what is more important, all its national elements were conserved and transmitted through an unspoiled literary Albanian language. All this was achieved by the immense contribution of De Rada and Cajupi. Our nation takes pride in the attainment these poets. Thus we can mention them not only for their pure patriotic feelings, but also for their literary and linguistic accomplishments in their poems.

The Albanian Renaissance is characterized by the development of a new ideology and culture under the influence of nationality and democracy; by the attempts of the most prominent writers to protect and increase the usage of the Albanian language by opening Albanian language schools and contributing to the development of the Albanian Literature. The political, social and philosophical thought was influenced by the illuminists and the most prominent intellectuals of that time, but it was also highly inspired by the Albanian literature. The writers Pashko Vaso, Sami Frashëri, De Rada, Asdreni, Mjeda, Çajupi etc. dedicated all their literary creations to the national issue by using a rich lexis and unspoiled language. Furthermore they were very attentive to transmit their creativity and philosophical thought to the Albanian readers.

Trying to leave aside the intention to assess the literary developments of this period in prose and poetry, we have decided to highlight some features of the language of poetry, which transmitted not only the aspirations and the high patriotic ideals, but even the finest flickers of the spirit of the artistic literature authors of that time. We will focus on the poetic works of the Renaissance writers De Rada and Çajupi, even though the latter, more than the romantic tendencies, showed realistic tendencies in his poetic work.

The methodology implemented for the realization of this work is of a complex character, because a descriptive approach will be combined with the analyzing and synthesizing one. The rich linguistic material offered from De Rada's and Çajupi's poetic masterpieces "Këngët e Milosaos" ("Milosao's Songs"), "Skënderbeu i pafan", "Serafina Topia", "Baba Tomorri" ("Father Tomorri"), "14 vjeç dhëndër" ("14-year-old groom"), has been selected and studied with the intention to highlight some particulars of the language of Renaissance poetry. The examples extracted from these works will serve for the illustration of the theoretical issues.

Some centuries ago, De Rada commenced the fifth song of the poem "Këngët e Milosaos" ("Milosao's Songs") with the line of a great message: "Erdh dit' e Arbrit!" ("Arber's day has come"). Along with the concern transmitted for the fate of the country, the poet was the first to provide the Albanian language with a masterpiece with a real poetic value, through which he would show that he looked after this language, which had been neglected for several years, and tried to raise 


\section{References}

The main Constitutional issues

Civil Code 1929

Law nr.601 dt.18.05.1948 "For the marriage"

Article nr.2083 dt.06.08.1955 " For the Property"

Family Code 1966

Family Code 1982

Family Code 2003

The Universal Declaration of the Human Rights

Law Nr.10428 dt.02/06/2011 " For the international private right"

Mandro.A et al. "The family Right" Tirane 2006

Zaka T. "The marital assets, Albanian jurisprudence, and some comparing systems" The library of the Justice Faculty Tirane Begeja K. "The family Right in the Republic of Albania" Tirane 1984

Bonilini G. "Commentary I of the family right " Milano 2004 (translation of the non public Justice Faculty "Luarasi" Tirane

Legal studio wordpress.com "The marital assets according to the marriage"

Albanian law diary blogspot.com "How to separate the assets in case of a divorce"

www.doctoratura unitir.edu.al 
such wealth. Cases are not rare and it is because the former spouses are not satisfied by the separation of property. Men claim to have put the wealth themselves and that their ex-wives did not contribute, since most of them are unemployed or homemakers.

"Hiding" the assets is mainly made by husbands, who, without starting the divorce separation of the assets, give these assets to any of his relatives or not declare it at all, as family property. Above all, the separation of property of spouses after divorce is not an easy process, which, for the sake of truth, in terms of the market economy is the most challenging, the most serious and that leaves the worst consequences for all former members of a divorced family, even their heirs. Marriage contract is a necessity to be calm in any case of the separation of marital property. If there is not such a contract before marriage and before a public notary, who has a legal obligation to bring this contract to the Office of Civil Status, making it an integral part of the act of concluding a marriage, husbands are presumed to have chosen legal regime of joined assets. This presumption means that, if a man has received a loan or has a liability to third parties, his wife has the obligation to third parties also.

In the world, especially in the Western countries, dominates the regime of separated marital assets. Each spouse has its own his wealth, and increases or reduces it. Given the principle of "every man for himself", any spouse uses its wealth for individual obligations, for the debts or various other loans.

Such a regime makes it possible to divide the assets between the spouses even when they are still married. But when such a contract does not exist, without the announcement of the divorce, their joined assets cannot be divided. With the new family Code in case of an absence of a prenuptial agreement, the marital assets are equality divided. If the former spouses still live in the same apartment, this place is divided in half, but when they live in separate houses, they should pay to the respective one the corresponding price according to the market value. In this case, the law is not in favor of the parent who takes care of the children, but favors the "woman" who raises them to profit a food allowance, which the father has to pay monthly. The new Family Code follows the line of equality, without favoring the wife, differently from the code in other countries such as Germany, France, and England which give more marital assets to the wife or the parent who raises the children.

\section{Conclusions}

After an analyses of the law basics of the marital assets in Albania we can say that even after so many years, even though the family relations have changed enormously, the new families and the young couples have the tendency not to have a prenuptial agreement, as it is perceived like a step toward the divorce.

In order for the young couples to have a quiet and correct marriage which fulfills their needs it is necessary for each of them to have separate assets. The difficulties that are seen in the development of a prenuptial agreement come as a result of:

A) An underdeveloped mentality of the parents of both spouses, who think that this agreement is an unfortunate step toward the development of marriage based on a contract.

B) Family assets are very scarce in Albania, where most of the part the spouses may only have a inherited home from their parents.

C) Most of the Albanian women are unemployed and have no assets, so they are not interested in a prenuptial agreement.

\section{Recommendations}

To create strong relationships and healthy families is necessary to have suitable marital asset collaboration in case of a divorce.

To inform the youth who want to create a new family, on designing a prenuptial agreement, because in most cases young people do not have a clear idea what does it consist of and what they benefit.

To have more information about innovations of the Family Code which can be obtained from the Civil Registry Office where the marriage would be taking place.

To have a precise definition of marital assets and in particular the administration of marital property as a necessity to create a strong and healthy family, to precisely define the method of administration of marital property which brings in itself a coordination of future family. 
of the established liability.

In cases of divorce, separation of the deposit would be made by the spouses themselves or by the court. According to this Code joined property was what each spouse inherited or was given by by any other legal source.

Changes in the society of the 90s in Albania impacted significantly on property relations between spouses. Up until the recent years the marital assets consisted of household items, personal items and income from work. With the legalization of private property on the "Main Constitutional Provisions" of the law number 7491 dated on 29.04.1991 every citizen had the opportunity to create or buy property or restitute the properties taken by the communist regime through law 7689 dated on 15.04.1993 " for the Restitution and Compensation of Property" so the property of the spouses got bigger. All these changes needed a better regulaiton for the marital assets. In 2003 the govenment approved the New Family Code which was mainly based on marital assets provided in the Codes of French and Italian states. The changed conditions made it possible to implement the contract freedom of the spouses. The right of the marital assest provides:

A) The conditions and limitations where the marital assets are available.

B) The part of the assets pertaining the liabilities

Seen in this aspect the marital assets have to do with the wealth issues related to family life.

The inovation of the 2003 Code is the provision of the marital assests. In the article 66 of this code is stated that: The marital assets of spouses is regulated by law in the absence of a special agreement, where both spouses foresee the agreement they deserve, which should not contrast the disposals of this Code and legislation".

According to this Code the marital assets are:

1. Joined marital assets

2. Prenuptial agreement

3. The divided assets

The joined marital wealth or the legal union foreseen in the $73^{\text {rd }}$ article of the Code, is stated that: "The marital assets of the legal union is implemented when the spouses do not have any prenuptial agreements made". This regime is the most difficult one in the divorce cases. As the divorce causes many consequences, many of the western countries have accepted divorce very late. Italy made the divorce legal only in 1970, Spain in 1982, Ireland still does not accept the right to divorce in its legislation.

If the spouses do not choose one of the ways the Code determines, automatically the marital assets will be administered in the form of joined assets. This means that the wealth made during the marriage will be divided equally to both spouses in case of a divorce. The wages, the financial contribute or other means of one spouse might be bigger, this does not play a role in the division. So, even in the cases when one of the spouses has not worked even a day in their life, still the wealth obtained during the marriage will be equally divided.

The inovation of this Code is the provision of hte prenuptial agreement and the regime of divided assets. The prenuptial agreement is a new concept of the Code approved in 2003, and is a judicial act through which the future spouses decide for the marital assets for the time the marriege will last. In this contract they decide what wealth will be joined and what will be individual. The contract is developed by a notery and not only does it serve a evedence in case of a divorce, but also for the fact of marriage validity. It aims to decie the future economic status of the family, it can decide conditions that are not provided in the Code but not contrary to the Code.

When a prenuptial agreement is developed both spouses should be fully exact what they ask for, provided in article 69. The contract may change as long as the marriage has not happened, in contrary the spouses might change it based on article 72 of the Code which states that:

"spouses may agree in the interes of the family to change the agreement partially or totally only after two years of its implementation. In this case it would be done in the same way as the initial contract......".

But the prenuptial agreements still does not have the right place in Albanian family for some reasons:

1. Firstly, albanians still have the old mentality and still respect the traditional way of marriage, which makes it very difficult to have a prenuptial agreement.

2. Secondly, albanians are not that wealthy to think that in the first moment with the marriage comes the division of the wealth. Most often they only have a house and work salaries.

Although the marriage contract is a new thing, couples in most cases overlook the reasons mentioned above. When the judge decides, he announces the biggest decision of your life from now on, as you will turn your single life, and the troubles have started. It is not at all surprising that the Albanian couples, when separated by a court, start arguing for 


\section{The Goal and the Objectives of the Study}

The aim of this study is to evaluate the reasons why this institute is not implemented in our country even though the law foresees it, and to give an evolution panorama this legislation has gone through in this direction.

The main objective:

To argument why the divided marital assets do not have the important place it should have in the life of Albanian society after 1990'.

\section{The Questions of the Study and the Methodology}

The question of this study is:

- Why the regime in collaboration is more important in Albanian marriages?

- Why the prenuptial agreement has not found its area of implementation in Albanian society?

- What are the difficulties that the Albanian courts encounter in the division of the marital assets?

This study has a qualitative approach, as we will legally analyze and compare the evolution of the institution in Albanian society and the Family law.

\section{Describing, Analyzing and Interpreting the Data}

The universal declaration of the human rights determines that "Family is the basic and natural unit of the society." Starting form this definition, we may say that putting family in this particular law aspect as the Family Code is of great importance in social relations.

When a new family is created, it is important to determine the marital assets, which the future spouses will have during their life together. The marital assets are seen since the begining of the human society and the family. Even in the Canun of Leke Dukagjini, even though wives did not have equal rights as the husband, if the couple divorced, the assets were divided too, in favor of the husband.

The first time that such a law on marital assest is seen was on the Civil Code of 1929, or said differently the Civil Code of King Zog. According to this law the couple should sign a contract at the notary as a public act, before the marriage took place. Even though this was very modern for the time being, influenced by the French Code, it did not treat any assets in favor of the woman, excluding the cases of the assets that came from the death of the husband. In 1948 the parliament approved the law number nr.601 dated 18.05.1948, "On the marriage". This law regulated the way the assets were divided and their administration. According to this law, the assets of each spouse before marriage remained theirs, but the assets created during the marriage was under both ownership. In case the spouses asked for the separation of their assets, thay had to go to court, which in return divided the assets based on the contribute each spouse had given.

Marital assets regulations was arranged later by the Decree nr.2083 dt.06.08.1955 "On ownership" which in particular provided joint ownership between spouses. According to this decree the wealth acquired through work during marriage belongs to both of the spouses overall, except the assets that each spouse brought from their family of origin. Liabilities that each spouse had before marriage and those of each spouse taken to their own interests the other spouse was not responsible. Also, under this decree, the legal transactions done from each of the spouses for the joined things, were valid, despite the fact that they could be carried out without consent of the other spouse.

The inovation of this decree was that for the first time was recognized the division of joint assets of the spouses during the marriage when there was reasonable cause and not just in cases of divorce.

On 23.06.1965 the Family Code was approved, in the law Nr.4020, which started to implement on 01.01.1966 and legalized the regulation of matrimonial assets. According to this code the property which was developed by working during marriage was joined property and any contrary agreement would be invalid. In these circumstances it can be said that if there was a prenuptial agreement from one of the spouses, stating that one of them waives the right of ownership on the assets doen by joined working during the marriage would be void contract.

The Family Code was approved in 06.29.1982 with the Law nr.6599, but the assets regulations continued to act based on the Civil Code of 1982. The inovation of this Code in relation to the marital assets was recognition of equality in having joined property, and expanded the circle of items which consisted of joint ownership of spouses after marriage. Although this code was innovative, the problem of cash deposits in the bank by one spouse remained unsolved. This problem would be resolved by Article 86 of the Civil Code according to which the spouse who did not deposit did not have any rights on savings deposits made by the other spouse because it was not a contracting party to the relationship 


\title{
The Marital Assets Issues in Albanian Legislation
}

\author{
Mimoza Mehilli \\ PhD Candidate at the European University of Tirana \\ Email:mehilli.mimoza@gmail.com
}

Doi:10.5901/ajis.2016.v5n3s1p309

\begin{abstract}
The right to marital assets is a right of future spouses, known from all the international legislations in variuos forms. In Albania, the marital assets is based on family rights forseen in the Code of French and Italian families. The marital assets treats the regulation of the common marital assest of spouses. The decision of having marital assets has evolutionalized from the begining of the family to nowdays. In the private international right this takes part as the family right. These assets are forseen in a prenuptial agreement in the moment the marriage happens, and after the event is not related to children, their treatment or care, but it is related only to the spouses and the way theirs assets are administered. In Albania the prenuptial agreement is seen initially in the Family Code of 2003, but its implementation is still not done as a result among others of albanian mentality. In albanian marriages there is not a prenuptial agreement which treats the premarriage asstes of each spouse before marriage. The changes this institution is developed in Albania from the countries the legislation is based, are still large. Through the analyses of the legislation and its implementation in the cases of divorce, this study gives a clear view of the importance of having a prenuptial ageement before marriage takes place.
\end{abstract}

Keywords: marital assets, prenuptial agreement, divorce, the right to marital assets, spouses.

\section{Introduction}

The marital assets and prenuptial agreement are two institutes of family law that are seen initially seen in the Family Code in a law implemented in 2003.

Both Family Codes issued earlier than 1966 and 1982 other than the legal property do not provide for any other type of assets. The main feature of this type of regime is the minimization of the assets independence of the spouses due to the restriction of their freedom of their prenuptial contract.

But social and economic changes that occurred in the 90s in Albania not only changed the economic and political system, but also the Albanian families and relationships. Despite the fact that even today after 26 years of changes, the idea that the spouses should not be dependent on one another but should contribute to the family assets still has not changed.

A prenuptial agreement does not necessarily mean that being married is short or is going to end, but puts both spouses on an equal situation and free to choose how to manage their wealth.

Every social and economic relation is always evolving and the matrimonial assets are constantly changing. This is best illustrated by the 2003 Family Code which is based on the family Codes of two developed countries, France and Italy.

But although the law and especially the Family Code provide legal marital assets, divided assets and prenuptial agreement, it is still not implied in Albanian marriages. This means that the courts often encounter the problem of dividing the marital assets in divorce cases and the fact that the most difficult issue is how to divide these assets than the divorce itself.

The biggest problems arise in cases of dividing the marital assets when one spouse has been unemployed during the marriage and this spouse risks to have nothing after the divorce despite having brought other benefits to families such as child care, taking care of the house etc.

This study will focus on the types of matrimonial assets and how they are applied in Albania after the 90s and the legal framework about these marital assets.

This paper will not analyze the Albanian legislation on this institute but will compare this legislation with previous legislations, in order to show the development of this institute from its beginning, from the 1929' Civil Code, up to the present day. 
To make an analysis of this thing, we have studied the correlation for qualitative variables (Bivariate Correlacion). For this purpose we have three tests that are Pearson and Spearman Kandall. The focus we decided just to ask the question if individuals want to live forever in Elbasan or not and for the variables shown above. From the table we see that there are strongly correlated with other qualitative variables.

\section{References}

Review of Economics and Statistics 49 (4 ): 48086. Bhagwati, J., and Srinivasan, T. 1974. On reanalyzing the Harris-Todaro model: Rankings in the case of sector specific Stidky wages.

American Economic Review 64: 502-8.

Brigg, P. 1971. Migration to urban areas. International Bank for Reconstruction and Development Staff Working Paper no. 107. --- 1973. Some economic interpretations of case studies of urban migration in developing countries. IBRD Staff Working Paper no. 151.

Byerlee, D. 1974. Rural-urban migration in Africa: Theory, policy and

research implications. International Migration Review 8, no. 4: 54366.

Portes, J., S. French (2005), The Impact of Free Movement of Workers from Central and Eastern Europe on the UK Labour Market: Early Evidence, Department for Work and Pensions Working Paper 18

Barnum, H. N., and Sabot, R. H. 1975a. Education, employment probabilities and rural-urban migration" in Tanzania. Paper presented at 1975 World Congress Econometric Society.

Migration, education and urban surplus labor. Paris: OECD Development Center, Employment Series. Beals, R. E.; Levy, M. B.; and Moses, L. N. 1967. Rationality and migration in Ghana. 
While in the following table and frequency of visits made to the village of origin, divided into several periods of. As shown by the results noted that $30 \%$ of the interviewees return to their village origin every 15 days, and $24 \%$ of them come back every 20 days. However, this fact is related with the short distance that have these villages with origin destination city.

Table 4: Frequency of village visits

\begin{tabular}{|lcc|}
\hline Period & Frequency & Percentage \\
\hline 1. Every 15 days & 15 & 30 \\
\hline 2. Every 20 days & 12 & 24 \\
\hline 3. Every month & 7 & 14 \\
\hline 4. Every 2 months & 8 & 16 \\
\hline 5. Every 6 months & 6 & 12 \\
\hline 6. Every year & 2 & 4 \\
\hline
\end{tabular}

The last issue that is treated related to remittances, specifically the manner of their use, and are listed in the following table:

Tabel 5: Ways of using income earned in the city

\begin{tabular}{|lcc|}
\hline Ways & Frequency & Percentage \\
\hline 1. Family Support & 11 & 22 \\
\hline 2. Personal Support & 11 & 22 \\
\hline 3. To built a new house & 4 & 8 \\
\hline 4. Children education & 19 & 38 \\
\hline 5. Buying a land & 3 & 6 \\
\hline 6. Other & 2 & 4 \\
\hline
\end{tabular}

As noted above results shows that most of of the income of migrants used for the education of children, taking care that $44 \%$ of the interviewees were married and with children. While only $6 \%$ of them have current plan you use the proceeds for the purchase of land, given the low incomes.

\section{Conclusions}

Migration of labor from rural to urban areas is an important part of the process of urbanization in developing countries. Migration is the answer of the difference between areas that encourage individuals to leave, usually to benefit higher income and to ensure jobs or more security and more rights.

$>$ Reasons for imbalance that cause migration are numerous and complex. Many of the migration causes related to countries that are in development, but the market, investment and other policies of industrialized countries can increase or to reduce the pressure of migration.

$>$ The migration presents a diversification strategy, and mobility of rural residents is often explained as a result of push factors and pull factors.

> Push factors refer to factors that promote and cause despair and involuntary migration, for example the absence of land, while the pull factors refer to those factors that cause voluntary migration , for example, higher wages in urban areas.

$>$ In fact from the analysis made on the data noted that the 285 people who answered the question if they want to live in Elbasan or not, we see that 278 answered yes. In these circumstances through models analysis are difficult because we have $97.5 \%$ of people who answered yes.

\section{Do you want to live forever in Elbasan?}

\begin{tabular}{|c|c|c|c|c|c|}
\hline & & frequencies & percentage & $\begin{array}{l}\text { \% percentage } \\
\text { On answered }\end{array}$ & $\begin{array}{l}\% \text { percentage } \\
\text { cummulative }\end{array}$ \\
\hline \multirow{3}{*}{ Values } & 0 & 7 & 2.5 & 2.5 & 2.5 \\
\hline & 1 & 278 & 97.5 & 97.5 & 100.0 \\
\hline & Total & 285 & 100.0 & 100.0 & \\
\hline
\end{tabular}




\section{Results of Questionnaires and Conclusions}

About $2 / 3$ of rural migrants, approximately $65.2 \%$ are aged 14 to 35 years old. The largest concentration of employees is observed in the age group 20-32 years. Rural migrant ages varying from 14-56 years old, but only $2.9 \%$ of respondents were over the age of 50 years old. It is clear that in Elbasan, is the youngest age population that tends and experimenting with internal migration. This age group of migrants has an essential characteristic on their marital status, approximately more than half of them are single (42.1 percent), or fiancés (13.6\%), and only $43.4 \%$ married. In terms of education level is seen that about $52 \%$ of the migrants are educated eight - year, and only $4 \%$ have completed higher studies.

Table 1: The characteristics of respondents

\begin{tabular}{|lcc|}
\hline Age & Frequency & Percentage \\
\hline $14-19$ & 5 & 10 \\
\hline $20-24$ & 17 & 34 \\
\hline $25-29$ & 11 & 22 \\
\hline $30-34$ & 4 & 8 \\
\hline $35-39$ & 5 & 10 \\
\hline $40-44$ & 2 & 4 \\
\hline $45-49$ & 4 & 8 \\
\hline $50-54$ & 2 & 4 \\
\hline Marital Status & & \\
\hline Single & 21 & 42 \\
\hline Engaged & 6 & 12 \\
\hline Married & 22 & 44 \\
\hline Divorced & 1 & 2 \\
\hline Level of education & & 12 \\
\hline None & 6 & 18 \\
\hline Primary & 9 & 52 \\
\hline Eight-year education & 26 & 8 \\
\hline Secondary & 4 & 6 \\
\hline Secondary profiled & 3 & 4 \\
\hline University & 2 & \\
\hline
\end{tabular}

Table 2: The reason of rural - urban migration

\begin{tabular}{|lcc|}
\hline The reason: & Frequency & Percentage \\
\hline 1. There are no employment opportunities in the countryside & 11 & 22 \\
\hline 2. Wages in rural areas are lower & 6 & 12 \\
\hline 3. Employment opportunities are rare in the countryside & 7 & 14 \\
\hline 4. Bed living conditions in the countryside & 8 & 16 \\
\hline 5. Ned for money & 5 & 10 \\
\hline 6. Work is seasonal in village & 6 & 12 \\
\hline 7. I haven't owned agricultural land & 5 & 10 \\
\hline 8. Other reason & 2 & 4 \\
\hline
\end{tabular}

As shown in the table above, most of of the interviewees, considered as one of the basic reasons of migration, limited employment opportunities in the village, about $22 \%$ of them. Also to be underlined is that $10 \%$ of them do not migrate as they have owned land.

The following table provides information on where migrants stay in the city?

Table 3:

\begin{tabular}{|lcc|}
\hline & Frequency & Percentage \\
\hline 1. With other employees or friends & 26 & 52 \\
\hline 2. With family & 9 & 18 \\
\hline 3. On the road & 8 & 16 \\
\hline 4. Other opportunities & 7 & 14 \\
\hline
\end{tabular}




\title{
The Effects of Rural to Urban Migration in the Region of Elbasan, Albania
}

\author{
Phd Candidate, Jonida Biçoku
}

\author{
Lecturer in Statistics, University of Elbasan, Faculty of Economy, Elbasan, Albania \\ Email:jbicoku@gmail.com
}

Prof.Dr. Fatmir Memaj

Deputy Dean, University of Tirana, Faculty of Economy

\section{Doi:10.5901/ajis.2016.v5n3s1p305}

\begin{abstract}
Migration seems to always be present within the cycle of the human life and sometimes it also seems inevitable. We are living in a time when migration in its logical and linguistic sense exists almost as a similiar phenomenon within time and space. In developing countries and in countries or regions with sustainable socioeconomic parameters it is presented with general typologies and almost unchanged ones. Migration is reasonably first related to the economic factor, but social circumstantial factors encourage and advance it. We are today facing people's movement towards larger urban centers for a more prosperous life, for more employment opportunities, in order to join family or social circles which migrated earlier and testify success stories. These stories are related to the fact of finding a job, often a stable one, which entails other expected, premeditated benefits. We will have to refer to the economic and identity picture, the chances, the opportunities and the environment of their implementation. Moving from one place to another, from a village to a city, or from one state to another, is often difficult. Problems consist in several elements but what makes the difference is the perspective point of view. An economist would undoubtedly head of by the market supply and the jobs' demand in the host city. A sociologist would understand all issues of economic security, and employment in particular, but would appreciate as a problem not at all secondary, the dealing with the unknown, the adaption to a new life and what is essential to life the social reintegration.
\end{abstract}

Keywords: Internal Migration, Urbanization, Human Mobility

\section{Objectives of study}

Giving the wellknown difficulties that face the population of the district of Elbasan in finding a productive employment, it is important to study the characteristics of workers who migrate from rural areas to urban areas. The study that is made through questionnaires and through case studies that will ensure the socio - economic profile of migrants, their motivations to migrate, and aspirations for the future. The main purpose of the study is to analyze the strategy that has been selected by rural migrants who face with limited economic opportunities in their villages, that is: rural - urban migration. Which are the mechanisms and networks of migration, for example in village conditions of origin, social and family networks, ways of traveling, and the type of migration (temporary, permanent, seasonal, return visits, etc.)? Investigation of lifestyle conditions and work experience of rural migrants that work in Elbasan District, How are the living conditions in urban labor markets, and how to compare these with the living conditions in their villages of origin?

\section{Methodology}

To respond at main objectives of this study I will refer to the results of questionnaires, specifically the interviews that were done with rural-urban migrants in this circuit. Questionnaires are main research instrument of this paper, therefore the main source of primary data. As a basis for data collection is used face-to-face interview through a short interview, with a duration of 15-25 minutes each. For this work, a total of 52 questionnaires were conducted to study the statistical relationships between variables. Surveys were conducted with rural migrant labor who face limited economic opportunities in their villages.

After data collection, processing them is using SPSS software. 


\section{Conclusion}

Companies operate in a dynamic environment that changes in cooperation and compliance with the influence of other factors or not. Because of this dynamism it is mandatory to have a good strategy in disposal, especially during financial crisis.

Results (outputs of the tasks) and the behaviors (work process entries ) are important in the process of assessing and measuring of performance.

The complexity of decision taking rises the need for statistical correlation method to explain the relationship between the environment of variables. In this situation, the income on the product is the result of conjugation many influencing variables, but not all the determined ratios have the same importance, the action of some of them compensating each other.

The case study model that was chosen is a representative one. Number of employees and price of product have a big impact on the level of sales revenue.

\section{References}

[1] http://www.afahc.ro/ro/afases/2014/manag/Fechete_Nedelcu_b.pdf

[2] http://www.appraisers.org/docs/default-source/discipline_rp/goeppner-multiple-regression-analysis_a-case-study.pdf?sfvrsn=2

[3] http://open.data.al

[4] http://web.stanford.edu/ hastie/Papers/ESLII.pdf

[5] http://www.monitor.al

[6] http://www.financa.gov.al

[7] http://www.lexjansen.com/nesug/nesug90/NESUG90009.pdf 


\section{Correlations}

\begin{tabular}{|ll|c|c|c|}
\hline & & Income & Nrofemploy & Prodprice \\
\hline \multirow{3}{*}{ Pearson Correlation } & Income & 1.000 & .887 & .342 \\
& Nrofemploy & .887 & 1.000 & .326 \\
& Prodprice & .342 & .326 & 1.000 \\
& Income &. & .000 & .167 \\
Sig. (1-tailed) & Nrofemploy & .000 &. & .179 \\
& Prodprice & .167 & .179 &. \\
$\mathrm{~N}$ & Income & 10 & 10 & 10 \\
& Nrofemploy & 10 & 10 & 10 \\
\hline
\end{tabular}

Variables Entered/Removeda

\begin{tabular}{|c|c|c|c|}
\hline Model & Variables Entered & Variables Removed & Method \\
\hline 1 & Prodprice, Nrofemployb & & Enter \\
\hline
\end{tabular}

a. Dependent Variable: Income

b. All requested variables entered.

Model Summary

\begin{tabular}{|c|c|c|c|c|c|c|c|c|}
\hline \multirow{2}{*}{ Model } & \multirow{2}{*}{$\mathrm{R}$} & \multirow{2}{*}{ R Square } & Adjusted R Square & \multirow{2}{*}{ Std. Error of the Estimate } & \multicolumn{4}{|c|}{ Change Statistics } \\
\cline { 6 - 9 } & & & & & & & \\
\hline 1 & $.889 \mathrm{a}$ & .789 & .729 & 51.775 & .789 & 13.125 & 2 & 7 \\
\hline
\end{tabular}

a. Predictors: (Constant), Prodprice, Nrofemploy

\begin{tabular}{|c|c|c|c|c|c|c|}
\hline \multicolumn{1}{|c|}{ ANOVA } & \\
\hline \multirow{2}{*}{1} & Model & Sum of Squares & df & Mean Square & $\mathrm{F}$ & Sig. \\
\hline & Regression & 70367.819 & 2 & 35183.909 & 13.125 & $.004^{\mathrm{b}}$ \\
& Residual & 18764.281 & 7 & 2680.612 & & \\
& Total & 89132.100 & 9 & & & \\
\hline
\end{tabular}

a. Dependent Variable: Income

b. Predictors: (Constant), Prodprice, Nrofemploy

Coefficients $^{\mathrm{a}}$

\begin{tabular}{|c|c|c|c|c|c|}
\hline \multirow{2}{*}{ Model } & \multicolumn{2}{|c|}{ Unstandardized Coefficients } & Standardized Coefficients & \multirow{2}{*}{$\mathrm{t}$} & \multirow{2}{*}{ Sig. } \\
\hline & B & Std. Error & Beta & & \\
\hline (Constant) & -86.121 & 144.820 & & -.595 & .571 \\
\hline 1 Nrofemploy & 1.458 & .308 & .867 & 4.729 & .002 \\
\hline Prodprice & .110 & .339 & .059 & .324 & .756 \\
\hline
\end{tabular}

a. Dependent Variable: Income

From the table of coefficients, the multiple linear regression model describing the relationship between this indicators of the economy subject of this research may be given in the following equation:

$Y=-86.121+1.458 x_{1}+0.110 x_{2}$

As it can be observed, the number of employer and the product price are the factors that significantly influence in the economy trends.

In the previous tables of statistical tests we see that the value of $\mathrm{R}$ and adjusted $\mathrm{R}^{2}$ is in the allowed limits to define the correctness of the created econometric model.

The negative value of the constant of 86.121 represents the fixed costs of a business. The correlation between number of employees and price of product is positive with the dependent variable. They are both significant for the model. Their significance can be valued from statistical tests that show a significance value smaller than 0.05 . 
Thus, it was established as a dependent variable the financial indicator total revenue, and as independent variables: number of employees and product price.

The shown equation gives the statistical model of multiple linear regression between a dependent variable (in our case income) and dependent variable (in our case number of employees and the price of product.)

To explain the variation of the dependent variable - total revenue - by its covariance with independent variables: number of employees and price we use a multiple linear regression statistical model defined by:

$y=a_{0}+a_{1} x_{1}+a_{2} x_{2}+\varepsilon$

In the above equation:

$Y=$ the explained variable - the financial indicator total revenue.

$\mathrm{x}_{1}=$ the explanatory variable 1 - number of employees.

$x_{2}=$ the explanatory variable 2 - product price.

$\mathrm{a}_{1}, \mathrm{a}_{2}=$ model parameters.

$\varepsilon=$ specification error, unknown (the difference between the true and the specified model);

$\mathrm{n}=$ total number of observations -10 fiscal years.

The model parameters give the change value of $y$ that corresponds with one unit change of $x$.

The tables below are taken from the SPSS and give the links between variables.

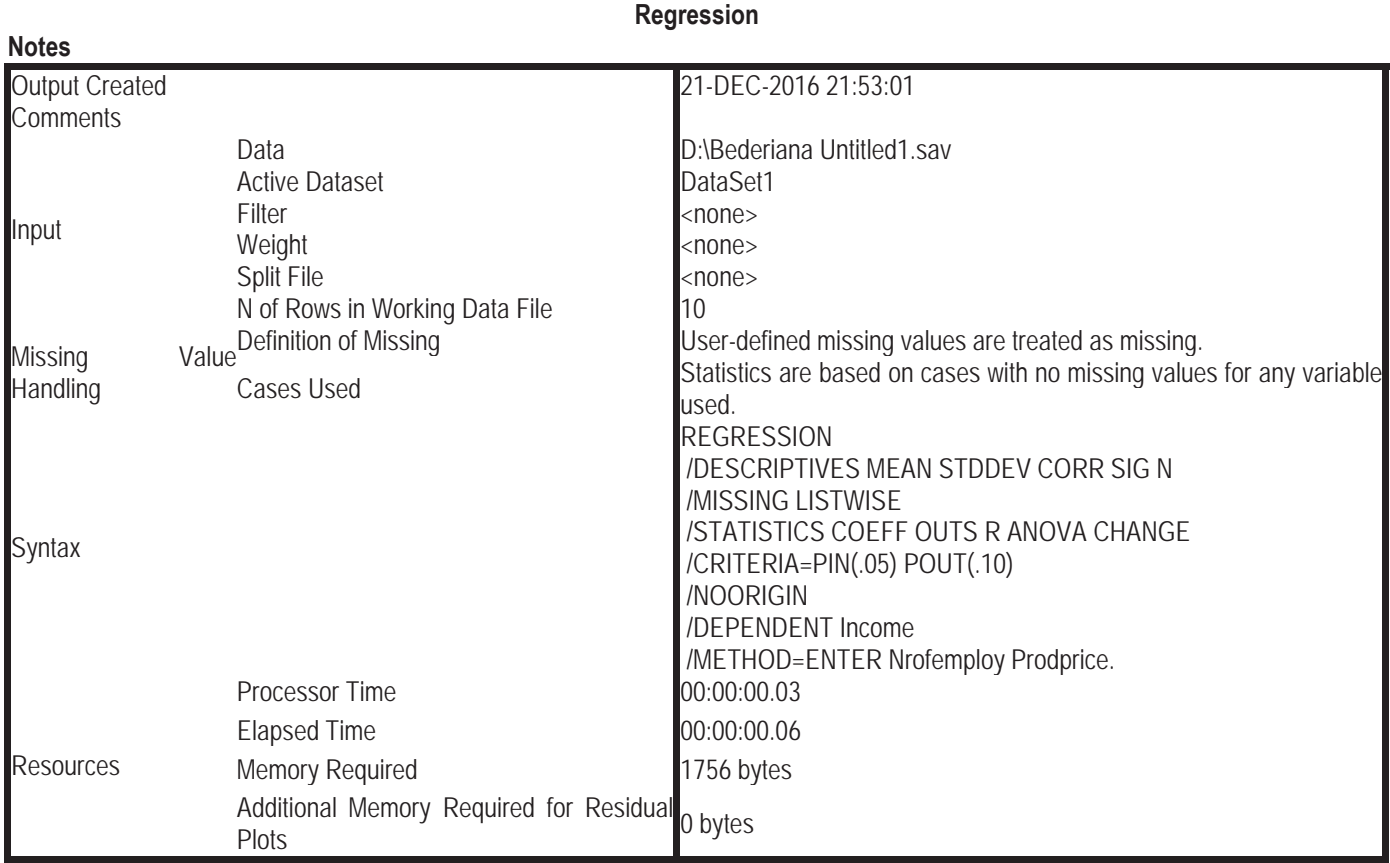

Descriptive Statistics

\begin{tabular}{|c|c|c|c|}
\hline & Mean & Std. Deviation & N \\
\hline Income & 124.70 & 99.517 & 10 \\
Nrofemploy & 111.00 & 59.200 & 10 \\
Prodprice & 446.00 & 53.790 & 10 \\
\hline
\end{tabular}


- to prove the correlation of the relationship that exist between this two variables.

Analysis of multiple regression is used to valuate a variable (dependent) in dependence to the values of independent variable, in order to express the amount of explanation of dependent variable in dependence of independent variable, finding all the units that help in ensuring a better explanation of dependent variable.

Let make the mathematical explanation of this problem of multiple linear regression:

Suppose that our variable $y$ depends from $n$ variables "non statistically independent" , $x_{1}, x_{2}, \ldots . x_{n}$, that are called independent variables. The problem of multiple regression is considered to be a model where is showed the function of these variables in the following form:

$y=f\left(x_{1}, x_{2}, \ldots, x_{n},\right)+\varepsilon$, in which :

$\varepsilon$ - random variable error or residue, and the $\varepsilon$ has the normal distribution $N\left(0, \sigma^{2}\right)$ and expresses the deviations of expected observed values of $y$ calculated through the regression equation.

Dependent variable y is also a casual unit normally distributed .

In the model of multiple linear regression:

- all the independent variables take part in the same time in the model

- the value of $\mathrm{R}$ and $\mathrm{R}^{2}$ determine the strongnees of the correlations between independent variables and dependent variable

- Fisher test is used to show if this connection determined by the election, may or no generalize for whole the population.

- $\mathrm{t}$ - test is used to evaluated the individual the link between every independent variable and the dependent variable.

One of major problems that appears during the creation of multiple regression model is the definition of the correlation of relationship in between variables:

For this purpose in multiple regression is defined a unit that is called the coefficient of multiple correlation $(R)$ that defines the amount of linear correlation in between the dependent variable $y$ and the independent variables $\left(x_{1}, x_{2}, \ldots x_{n}\right)$.

This coefficient takes defined values. If the distribution values are near the medium, the linear dependency is perfect so $\mathrm{Y}$ can be expressed exactly as a linear combination of $\mathrm{X}_{1}, \mathrm{X}_{2}, \ldots . \mathrm{x}_{\mathrm{n}}$ and in this case the model of linar regression is too strong.

Beside the values of $R$ in consideration should be taken also the value of $R^{2}$ that defines the part of variance of $Y$ that is "explained "from the connection of relation $\mathrm{x}_{1}, \mathrm{x}_{2}, \ldots . \mathrm{x}_{\mathrm{n}}$.

This coefficient is dependent from the degree of measurement of random variables that are part of the model. Bigger is the number of variables, bigger will be the value of $\mathrm{R}^{2}$, because the expected error of prediction will be smaller.

Even if we are using reliable data, a big $\mathrm{R}^{2}$ does not necessarily means that there is a strong causal relationship, follows that, on the basis of regression, it is not possible to determine causation. [1]

\section{The Analyses of Fenomena Using Multiple Linear Regression-Case Study}

Method of multiple linear regression analysis is used to show the connection that exists among variables and to make concrete this relation.

For this purpose all the data is used in following table, gathered from opendata.al and gives the income in dependence of number of employees and the price of the product.

In this regard the following financial ratios derived from the organization studied during years 2005-2015: incomes, number of employees, and product price, as described in the below table will be taken into consideration.

\begin{tabular}{|c|c|c|c|}
\hline Years & Incomes (/000000 ALL) & Nr. of employees & Product Price \\
\hline 2015 & 56 & 50 & 500 \\
\hline 2014 & 79 & 71 & 500 \\
\hline 2013 & 99 & 109 & 500 \\
\hline 2012 & 350 & 188 & 470 \\
\hline 2011 & 242 & 211 & 470 \\
\hline 2010 & 155 & 176 & 470 \\
\hline 2009 & 103 & 100 & 400 \\
\hline 2008 & 78 & 86 & 400 \\
\hline 2006 & 48 & 62 & 400 \\
\hline 2005 & 37 & 57 & 350 \\
\hline
\end{tabular}




\title{
Multiple Regressions for the Financial Analysis of Alabanian Economy
}

\author{
Assoc.Prof.Dr. Bederiana Shyti \\ Head of Department of Mathematics, Faculty of Natural Sciences, University "Aleksander Xhuvani” Elbasan, Albania \\ Email: bederiana.shyti@uniel.edu.al \\ Ilva Isa \\ Ph.D student, Carlo Cattaneo University, LIUC \\ Email: iisa@liuc.it

\section{Silvana Paralloi} \\ Msc in Applied Mathematics
}

\section{Doi:10.5901/ajis.2016.v5n3s1p300}

\begin{abstract}
Fulfillment of strategic, managerial and operational decisions is the ultimate aim of any company. Economic performance is to be evaluated on the basis of effectiveness and efficiency of use of resources. The aim of this paper is to study economical phenomena through a statistical point of view. Our motivation is to emphasize the validity of the regression analysis in economic performance. Multiple regression analysis will be applied to demonstrate the trend of economic trend of transitory economy of Albania. The whole paper will be as a case study on a limited liability company in the production industry. There are a few processes from raw material to final product. Regression analysis, correlation analysis, ANOVA are used to represent a mathematic-statistical model to analyse the economic progress of the company depending of the used indicators. The main goal of statistical analysis used in the paper, is to demonstrate the kind of relationship between the variables, presented by a equation of multiple linear regression (in our case one dependent and two independent variables). SPSS 17.5 will be used to evaluate the statistical results.
\end{abstract}

Keywords: Multiple regression, economic performance, financial analysis

\section{Introduction}

In the continuous progress of an enterprise strategic, managerial and operational management is very important. In order to evaluate the extant at which the enterprise goals are achieved it is imperative to define an integrated system of indicators that can tell us at any time if our business is going in right direction or not.

Our main reason for compelling the financial statements is to provide a better decision taking, diagnosis of the current situation of a business and future perspective.

Plain cost and profit are not the main aim of the enterprise, we want to study how qualitative the earning is, what is the sale revenue, which one of the indicators best reflects the economic progress of the enterprise.

For this purpose the multiple regression analysis will be used to demonstrate the trend of economic trend of transitory economy of Albania.

To have a better understanding we will apply the regression model in a case study. Our case will be a company with foreign capital in the construction and trade industry.

\section{Research Method}

Three types of analysis will be used: regression analysis, correlation analysis, ANOVA. The objective of analysis is control of the relationship between dependent and independent variables exists and if so, does it aims to use the existing information for dependent and independent variables, in order to improve the correctness of prediction of the values of dependent variable.

In our study we have used multiple regression analysis and through this analysis we aim to achieve:

- the valuation of the connection between the variables; two independent and one dependent variable. 
concerns and difficulties for concentration and lesson comprehension by the students. On the other hand, it is highlighted that soft tones of voice, calm and docile speaking makes the students not only feel more comfortable, but also to be more motivated in lessons.

Further, by comparing male and female students, we generally note differences in the perception of verbal communication between genders and that female students are those dominating with highest academic performance.

\section{References}

Argyle, M. (1977). Bodily communication. New York. International Universities Press.

Austin, J. L. (1962). How to do things with words. Oxford. Oxford University Press.

Bateson, G., J. Ruesch. (1951). Communication: The Social Matrix of Psychiatry. New York. Norton.

Borman, E. G. (1988). Symbolic convergence theory: a communication formulations based on hommo narrens. Journal of Communication, 35: 128-39.

Brekelmans, M., Levy, J., Rodriguez, R. (1993). A typology of teacher communication style. In T. Wubbels., J. Levy, Do you know what you look like? Londra. The Falmer Press.

Butterworth, B. (1978). Maxims for studying conversations, Semiotica, 24, 217-229.

De Saussure, F. (1983). Course in General Linguistics. Chicago. Open Court Classics.

Fiorani, E. (1998). Grammatica della comunicazione Milano. Lupetti.

Hoben, J. B. (1954). English Communication at Colgate Re-examined. Journal of Communication 4: 77.

Jakobson, R. (1966). Saggi di linguistica generale. Milano. Feltrinelli.

Littlejohn, S., Foss, K. (2005). Theories of human communication. Belmont. Thomson-Wadswoth.

Miller, K. (2002). Communication Theories: Perspectives, Processes, and Contexts. Boston. McGraw-Hill.

Patrick, B. C., Hisley, J. \& Kempler, T. (2000). "What's everybody so excited about?" The effects of teacher enthusiasm on student intrinsic motivation and vitality. The Journal of Experimental Education, 68(3), 217-236.

Pearce, W. B. (1989). Communication and the human condition. Carbondale. Southern Illinois University Press.

Peirce, C. S. (1980). Semiotica. I fondamenti della semiotica cognitiva. Torino. Einaudi.

Rosengren, K. E. (2001). Introduzione allo studio della comunicazione. Bolognia. II Mulino.

Searle, J. R. (1979). Speech acts. Cambridge. Cambridge University Press.

Shannon, C., Weaver, W. (1949). The mathematical theory of communication. Urbana. University of Illinois Press,

Watzlawick, P., Beavin, J. H., Jackson, D. D. (2008). Pragmatica della Comunicazione Umana Studio dei Modelli Interattivi Delle Patologie e dei Paradossi. Romë. Astrolabio.

Zimmerman, B. J. (2001). Self-regulated learning and academic achievement theoretical perspectives. In B. J. Zimmerman \& D. H. Schunk, Theories of selfregulated learning and academic achievement: An overview and analysis. Mahwah. Lawrence Erlbaum Associates. 
females with $55.1 \%$ and for males with $44.9 \%$. Mostly, there are students who have low academic results or learning by this method of communication, while for most of them, with around $67.1 \%$, raised voice or screaming during lessons by the teacher constitute a concern, where female students respectively agreed and fully agreed with this fact in $63.1 \%$ and $53.8 \%$, because according to them, this makes the subject more difficult. Following the pedagogical practice and various studies of this field, it is clearly highlighted that proper communication is often the key of success in the teacher-student relations. As it is often heard, the students do not learn the subject merely because of the mode of behavior of the relevant teacher.

When questioned about the fact: - The words chosen by the teacher during the lesson are not very important, what matters is to give them meaning, in $48 \%$ of cases the students agreed or fully agreed, respectively the females amounted to $52.8 \%$ and $47 \%$. Male students who represented $47.2 \%$ agreed and fully agreed, a little more than females, thus accounting for $53 \%$ and $46 \%$ did not agree, namely they did not agree, where $59.3 \%$ are female students and $40.7 \%$ males.

The assumption: - When the teacher is too spared in words during explanation, I fail to fully understand the lesson, this is true for $62.8 \%$ of the interrogated students, namely they agreed, especially the students who are attentive and carefully follow the lesson while explaining new knowledge or special lesson-related issues. Even $59.2 \%$ and $61.8 \%$ of those who respectively agreed or fully agreed are females and the rest are males, respectively with $40.8 \%$ and $38.2 \%$. For $24.3 \%$ the spared words in lessons do not represent an issue of concern, where males occupy the largest percentage, respectively $54.7 \%$ did not agree at all and $51.5 \%$ partly agreed, while the rest of them, $12.8 \%$ have maintained an unbiased position.

Table no. 4 propvides a summary of the students' answers on verbal communication.

Table 4. Evaluation about verbal communication

\begin{tabular}{|c|c|c|c|c|c|c|c|c|c|c|c|c|}
\hline \multirow[b]{2}{*}{ Communication } & \multicolumn{12}{|c|}{ Evaluation about verbal communication } \\
\hline & $\begin{array}{l}\text { Strongly } \\
\text { disagree }\end{array}$ & $\%$ & $\begin{array}{l}\text { Partly } \\
\text { agree }\end{array}$ & $\%$ & Neutral & $\%$ & Agreed & $\%$ & $\begin{array}{l}\text { Strongly } \\
\text { agree }\end{array}$ & $\%$ & Total & $\%$ \\
\hline $\begin{array}{l}\text { Do you agree with the fact that when the teacher } \\
\text { uses encouraging words during explanation, you } \\
\text { manage to be more motivated in lessons? }\end{array}$ & 78 & 7.4 & 169 & 16.1 & 110 & 10.5 & 423 & 40.3 & 270 & 25.7 & & $\mid 100.0$ \\
\hline $\begin{array}{l}\text { To what extent do you agree with the fact that } \\
\text { when the teacher does not choose proper words } \\
\text { for the lesson, you fail to understand? }\end{array}$ & 147 & 14.0 & 157 & 15.0 & 92 & 8.8 & 265 & 25.2 & 389 & 37.0 & 1050 & 100.0 \\
\hline $\begin{array}{l}\text { When the teacher speaks with dialect, the lesson } \\
\text { becomes more difficult for me to understand. }\end{array}$ & 165 & 15.7 & 167 & 15.9 & 115 & 11.0 & 246 & 23.4 & 357 & 34.0 & 1050 & 100.0 \\
\hline $\begin{array}{l}\text { The words chosen by the teacher during lesson } \\
\text { do not matter much, what matters is to give them } \\
\text { meaning. }\end{array}$ & 258 & 24.6 & 224 & 21.3 & 169 & 16.1 & 216 & 20.6 & 183 & 17.4 & 1050 & 100.0 \\
\hline $\begin{array}{l}\text { When the teacher is too spared in words during } \\
\text { explanation, I fail to fully understand the lesson. }\end{array}$ & 86 & 8.2 & 171 & 16.3 & 134 & 12.8 & 316 & 30.1 & 343 & 32.7 & 1050 & 100.0 \\
\hline $\begin{array}{l}\text { When the teacher continuously raises voice } \\
\text { (screams) during lesson, I find it hard to learn } \\
\text { this subject/module. } \\
\end{array}$ & 89 & 8.5 & 141 & 13.4 & 105 & 10.0 & 260 & 24.8 & 455 & 43.3 & 1050 & 100.0 \\
\hline $\begin{array}{l}\text { When the teacher speaks in quiet and docile } \\
\text { voice, I am prone to be motivated in lessons. }\end{array}$ & 46 & 4.4 & 85 & 8.1 & 114 & 10.9 & 254 & 24.2 & 551 & 52.5 & 1050 & 100.0 \\
\hline $\begin{array}{l}\text { When the teacher always speaks at the same } \\
\text { pace, I lose interest in lessons. }\end{array}$ & 251 & 23.9 & 210 & 20.0 & 191 & 18.2 & 217 & 20.7 & 181 & 17.2 & 1050 & 100.0 \\
\hline
\end{tabular}

\section{Conclusions}

Based on the study and the analysis conducted, we may state that:

Choice of proper words during learning process at school is paid special importance by the students, not only to acquire new knowledge during lessons, but also to be more clear and motivated. The use of slang words by more than half of the students is not regarded as a good option for the more effective meaning of lesson.

Further, it is observed a high trend to assess the para-verbal or pre-linguistic aspects of communication, such as voice pitch, intonation, pace, timbre etc, where especially a prolonged use of the high pitch of voice by the teacher brings 
academic performance, respectively by $74.7 \%$ and $86.7 \%$. Regarding the average level, $52.6 \%$ of the students who have declared of having an average level of results are females and the remainder of $47.4 \%$ are males. Also, among the students who state of having a high level, 173 or $69.8 \%$ are females and the remainder of 75 students or $32.2 \%$ are males. The same trend is also observed with the very high level of results, where again females prevail with $67.2 \%$ over males with $32.8 \%$ (table 2).

Table 2. Analysis between gender and the assessment for the educational level of the students

\begin{tabular}{|c|c|c|c|c|c|c|c|c|c|c|c|c|}
\hline \multirow{2}{*}{ Gender } & \multicolumn{9}{|c|}{ How do you evaluate your level of education? } & \\
\cline { 2 - 15 } & Very low & $\%$ & Low & $\%$ & Average & $\%$ & High & $\%$ & Very high & $\%$ & Total & $\%$ \\
\hline Female & 2 & $.3 \%$ & 24 & $4.1 \%$ & 292 & $50.1 \%$ & 173 & $29.7 \%$ & 92 & $15.8 \%$ & 583 & $100.0 \%$ \\
\hline$\%$ & $13.3 \%$ & & $25.3 \%$ & & $52.6 \%$ & & $69.8 \%$ & & $67.2 \%$ & & $55.5 \%$ & \\
\hline Male & 13 & $2.8 \%$ & 71 & $15.2 \%$ & 263 & $56.3 \%$ & 75 & $16.1 \%$ & 45 & $9.6 \%$ & 467 & $100.0 \%$ \\
\hline$\%$ & $86.7 \%$ & & $74.7 \%$ & & $47.4 \%$ & & $30.2 \%$ & & $32.8 \%$ & & $44.5 \%$ & \\
\hline Total & 15 & $1.4 \%$ & 95 & $9.0 \%$ & 555 & $52.9 \%$ & 248 & $23.6 \%$ & 137 & $13.0 \%$ & 1050 & $100.0 \%$ \\
\hline$\%$ & $100.0 \%$ & & $100.0 \%$ & & $100.0 \%$ & & $100.0 \%$ & & $100.0 \%$ & & $100.0 \%$ & \\
\hline
\end{tabular}

Referring to their educational level, this is also reflected in the descriptive statistics regarding their average grade. Thus, according to data of the following table, it is observed that the average declared sample grade is 8.1, the lowest grade is 4.5 and the highest grade is 10 (table 3 ).

Table 3. Descriptive statistics for the average grade of the students

\begin{tabular}{|c|c|c|c|c|c|c|}
\hline & Number & Minimum & Maximum & Average grade & Standard deviation & Variance \\
\hline Your grade average & 1050 & 4.5 & 10.0 & 8.1 & 1.19 & 1.41 \\
\hline
\end{tabular}

Regarding one of the questions on verbal communication, the respondents answered as follows: Question - When the teacher uses stimulating words during explanation, do you manage to be more motivated in the lesson?, 40.3\% agreed and $25.7 \%$ stated they fully agreed, where more than half or $51.9 \%$ of those who agreed, are females and $40.9 \%$ are males. Further, $23.5 \%$ of them stated they did not agree or did not agree at all and mostly the males are those who provided such answers, with $60.3 \%$ and $51.5 \%$, respectively did not agree and partly agreed.

The rest of them adopted an impartial position, without preferring to see it as a motivating factor for them. By analyzing this phenomenon in connection with the academic performance, we observe that $68.6 \%$ of the students with high results agreed or fully agreed. The same are also the students with high results, while $16.8 \%$ of the students with poor results partly agreed and the same number stated they did not agree at all with the fact that use of stimulating words during explanation motivates them more. $20 \%$ of those students with very poor results stated they did not agree at all and $26.7 \%$ thereof partly agreed, but there are also students, who despite the poor academic performance, reconcile with the fact that stimulating words serve as a good motivation for them. This category represents $53.3 \%$, while the rest are impartial in their answers.

As regards the assumption- When the teacher does not select proper words for the lesson, you fail to understand it, $62.2 \%$ of the students stated they agreed or fully agreed.

The females express their consent in more than half of these answers, with $57.7 \%$ who agreed and fully agreed in $60.9 \%$, while males respectively by $42.3 \%$ and $39.1 \%$. $8.8 \%$ are impartial and the rest did not agree with the fact that choice of words by the teachers is the solution to better understand the lesson.

As regards the assumption: - When the teacher speaks dialect language, the lesson becomes harder for them to understand, answers have shown this is true for $56.4 \%$ of the students, namely the communication by the teacher in dialect language renders somewhat more difficult the understanding of lesson for them. $11 \%$ of the interviewed students have adopted an impartial position and for $31.6 \%$, namely around $1 / 3$ thereof, communication with them in dialect language does not represent a concern ( $46.1 \%$ of those, who are not disturbed by dialect language, are females). Furthermore, there are more females who partly agreed, with $55.1 \%$ and males with $44.9 \%$. This also occurs because in large cities, mostly in Tiranë, the students come from the area where the same dialect is spoken and dot not represent an issue of concern.

Regarding the assumption: - When the teacher continuously raises the voice (screams) in the lesson, then I can hardly learn this subject, for $21.4 \%$ of the total number of students, this does not represent a concern, especially for 
Albania, where the number of public and non-public schools is higher, including in the questionnaire at the same time the students of all levels (classes 10-12).

Over 1050 students are questioned via questionnaire. The participating respondents were randomly chosen being of different genders and ages. They studied in classes of different levels, thus making the sample more representative.

The sampling method was selected in such a way as to provide comprehensive data. The study was extended to the cities with the largest number of public and non-public schools, respectively of the students who carry out didacticeducational activities therein. They are: Shkodra in the Northern Albania; Durrës and Tirana in the Middle Albania and Vlora in the Southern Albania (table 1).

Table 1. Distribution of students by city

\begin{tabular}{|c|c|c|}
\hline City & Frequency & Percentage \\
\hline Durrës & 209 & 19.9 \\
\hline Shkodër & 166 & 15.8 \\
\hline Tiranë & 545 & 51.9 \\
\hline Vlorë & 130 & 12.4 \\
\hline Total & 1050 & 100.0 \\
\hline
\end{tabular}

Regarding the classification by gender, the following graph shows that $55.5 \%$ of the students who have attended the study are females and the remainder, namely $44.5 \%$ are males, knowing that the ratio of females to males at national leve lis generally higher.

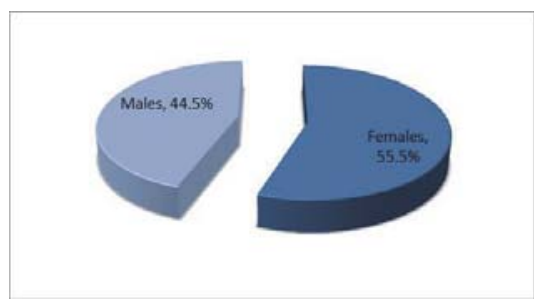

Graph 1. Participation of students by gender

The interviewees have an average age of 16.5 years old, while the minimum age of the interviewees is 15 years old and the maximum age is 20 years old. The study has also included professional schools with a 4-year time span.

\section{Data Analysis}

The students are also questioned about their educational level (academic results achieved) and the answers are listed as follows: half of them, $50.3 \%$ have declared they have an average academic performance, followed by $28.5 \%$ of the students, who stated that their educational level is higher and the remainder had a very high level of $12.4 \%$. However, data show that also in $7.4 \%$ of the cases, their level is poor and for $1.4 \%$ the academic level is very poor (graph 2).

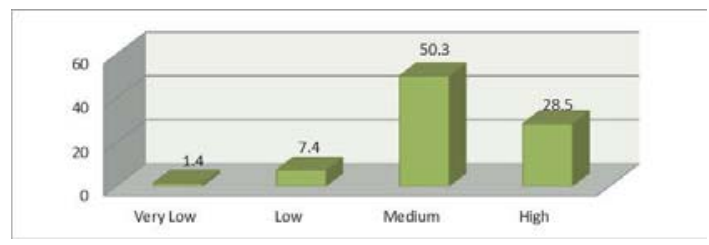

Graph 2. The evaluation of the learning level

Further, by analyzing the level and results with gender, we observe that boys generally have a poor or very poor 


\title{
Perception of Verbal Communication of the Teacher in the Classroom by Pupils of Different Genders (Females-Males)
}

\author{
Dr. Gentjana Panxhi \\ Lecturer at the Faculty of Education, "Aleksandër Moisiu" Durrës University \\ Email: genta_panxhi@yahoo.com
}

\section{Doi:10.5901/ajis.2016.v5n3s1p295}

\section{Abstract}

\begin{abstract}
Verbal communication which mainly provided through the word is a form of communication which is realized not only in life but also in the teaching process. This kind of communication during the teaching process should not only serve to simplify reality, for transmission and organization of knowledge, to remind the experience of the past, but should also aim at the creation of a favorable climate in the classroom, as well as encouraging pupils for the higher results cognitive and affective. But equally is perceived, and has a difference in his meaning by the pupils of different genders (females-males), and whether this affects the school performance of these students? These and other aspects of communication are the main object of this research. Through this study aims to explore how are perceived some aspects of verbal communication to the teachers, to the pupils of different genders, and to identify the correlation between the perception of verbal communication of the teacher and school performance of students. To achieve the objectives of the paper were conducted on the ground survey at middle school, asking at the same time students of different genders, ages, classes and different levels, distributed in four cities of Albania.
\end{abstract}

Keywords: verbal communication, pupils, teacher, teaching process, performance, gender.

\section{Introduction}

Apart from the approach as a key means in the process of socialization and building inter-personal relations, communication also serves as one of the most crucial elements of learning, not to mention that the learning process may be regarded as a continuous flow of communication Exchange by which not only knowledge and ideas are transmitted, but also as a flow of communication relations. Accordingly, both in the concept of classical learning and modern pedagogy, the teacher-1-student communication relations are treated as an extension of teacher-student relations over space and time. Furthermore, two main forms of communication are defined, namely the verbal communication (by words, listening, writing and reading) and non-verbal communication (any kind of communication apart from the verbal one). This type of communication is displayed not only in daily life, but is also reflected in the learning-educational process.

Multiple definitions on communication are encountered over time. Researchers of the field of communication introduce various definitions, and sometimes concepts that contradict each other. What we notice, is that we cannot find a definition reconciling the theoreticians of communication sciences with a unique view on communication. By the term "communication", Shannon and Weaver implied all procedures through which one mind influences another (Shannon and Weaver, 1949: 95).

Further, according to Hoben, communication is the verbal exchange of a thought or idea (Hoben, J., 1954: 76).

For Watzlawick $(1967,2008)$, communication is "a process of interaction between various communicating persons".

\section{Methodology of Study}

In order to achieve the objectives of this study, to deliver the opinion of students about the teacher's verbal communication, field questionnaires were realized, specifically from high school students in the four largest cities of

${ }^{1}$ The term "teacher" implies both genders. This is also stressed by the fact that in all educational cycles the teachers are higher in number. 
Calculating the poverty level based on total household income ( $\mathrm{THI}$ ) shows that family members are living over complete poverty on all types of farms. This proves that off- farm income constitutes a very important source of income for the family members of some types of farms in Berati Region.

\section{Conclusions}

The economic performance of agricultural units in Berati region, in terms of productivity and viability, still are not justifying their importance. Hence, as it was argued, some of farms were repaying the work force but were not utilizing with efficiency their agricultural land. For example, clusters such as, self-sufficiency, leisure and specialized fruit trees resulted not productive when compared to other clusters. Furthermore, considering the viability dimension of agricultural units in Berati region, except the Poly culture and Livestock clusters, all other clusters are not giving a significant contribution to the standard of living of farm household members.

Therefore, when FNI/HM is analysed in terms of extreme poverty, its role is not significant to all clusters, with the exception of the Poly culture and Livestock clusters because the coefficients are close to 1 (the line of extreme poverty).

Considering the role of $\mathrm{TH}$ in terms of extreme poverty, all farm clusters offer a significant contribution to standards of living of household members. This means that, the THI remains a very important source of farm household members in Berati Region. Furthermore, even in terms of complete poverty, the role of $\mathrm{THI}$ remains significantly important for farm household members in Berati region.

Poly culture in agriculture can provide several positive effects, but it is not likely to be a long term strategy for agricultural development. In addition, development of livestock, particularly cattle and small ruminants, should be considered and evaluated as a long-term strategy of agriculture development in Berati region.

\section{References}

The impact of policy instruments on the farming systems in Albania. Joint Research Centre, Institute for Prospective Technological Studies, Seville/Spain. Financed by: European Commission 


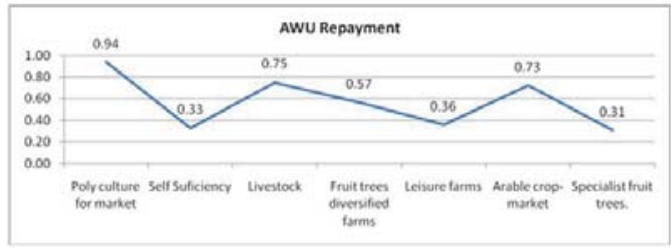

Figure 5. Annual work unit repayment

Only in the poly culture for market the labour is paid nearly $94 \%$ of the minimal wage. In livestock and arable crop for market farms work is paid at $75 \%$ of minimal wage. The work in agriculture and outside agriculture is paid more than the minimal wage in leisure, fruit trees diversified and arable crop market farms. The work in agriculture and outside agriculture is paid as much as the minimal wage in the poly culture for market farms and nearly $89 \%$ of the minimal wage in livestock farms.

\subsubsection{FNI/THI per household member and extreme poverty}

For farms that have agriculture activities as their main source of income, their household members are living over extreme poverty line.

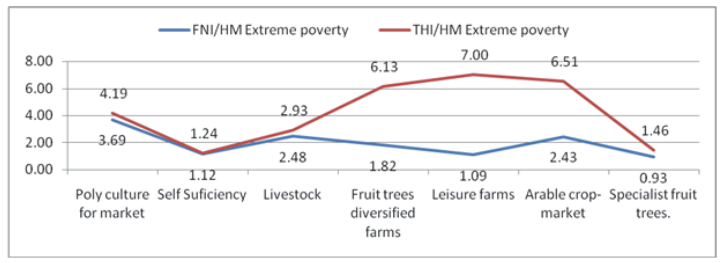

Figure 6. FNI/THI per household member and extreme poverty

Thus, as it is seen on the Figure 6 all farms types with the exception of the specialist fruit trees, consider agricultural activity as the most important source of revenues. In addition, for farms that are part of specialist fruit trees cluster, agriculture is not an important source for revenues. For further analysis, we can say that the more diversified a farm is the more effective it becomes. When it comes to the THI role as to the standard of living of farm household members in this region, it is clear that it has an important influence on most of clusters such as, Fruit trees diversified, Leisure, and Arable crop for market. Hence, for these three clusters as compared to the others, the off-farm and not on farm income is very important for the standard of living in terms of extreme poverty.

\subsubsection{FNI/THI per household member in complete (full) poverty}

Regarding the standard of living of clusters' household members, in terms of complete poverty, with regard to the FNI, we can say that farm clusters' household members such as poly culture for market, livestock, fruit trees and arable crop market are living over complete poverty. In contrast to this, the household members of clusters farms such as, selfsufficiency, leisure, and specialized fruit trees are living below the complete poverty.

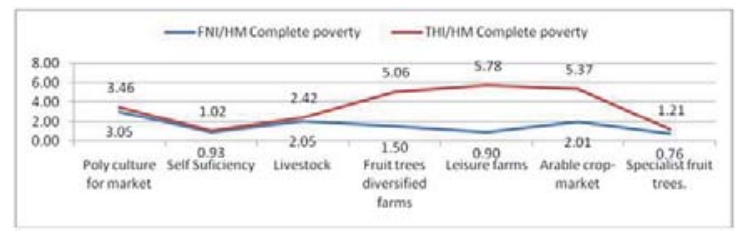

Figure 7. FNI/THI per household member and complete poverty 


\subsection{Farm productivity}

\subsubsection{Farm Net Income per Annual Work Unit}

As it is seen in Figure 44, the clusters of Poly Culture for Market, Fruit Trees diversified, Arable Crop Market and Livestock farms are better performing in terms of FNI/AWU than the other clusters. Labour productivity is higher in these clusters because it is known the fact that one of the advantages of production diversification and livestock production is the full usage of labour. Furthermore, work force is better used in these clusters and they are economically better than the others. As it is seen, in Albanian agriculture, farms that are diversified are better performing than specialized farms in terms of FNI/AWU.

Labour productivity is lower in Self-sufficient and specialized clusters. Regarding Self-sufficient farms, as a result of their main purpose for producing mainly for self consumption, justify the low performance in terms of FNI/AWU. This is due to the fact that these farms are not much interested or able to be economically effective even in terms of FNI/AWU.

Concerning the specialised farms, such as Specialist fruit trees, with regard to investments it can be said that they are not yet effective because of the production cycle of fruit trees. A single activity should be more profitable for justifying the idle labour and production resources during certain periods of the year.

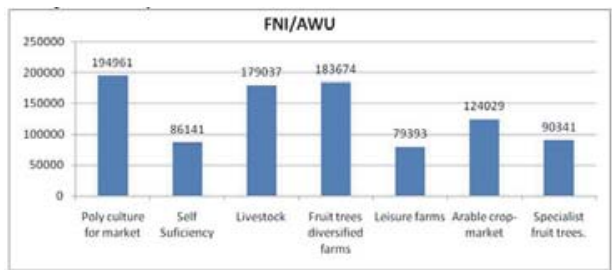

Figure 3. Farm Net Income per Annual Work Unit

\subsubsection{Farm Net Income per Utilized Agricultural Area (FNI/UAA)}

The land effective use is higher on diversified farms and livestock farms. This is due to the fact that vegetables and livestock products are part of the activities with high added value. Land productivity is lower in subsistence farms, leisure farms and specialized for fruits farms. The poly culture for market and livestock farms must be object of financial support from government in the future in Berati Region.

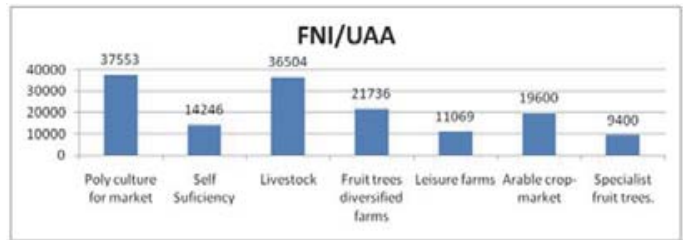

Figure 4. Farm Net Income per Utilized Agricultural Area

It is a known fact that in part-time farms (leisure farms), farm income does not constitute the main source of income for the family. The low level of income in specialized farms for fruits has to do with the fact that production in new orchards during the first years of their economic life is low.

\subsection{Farm viability}

\subsubsection{FNI/AWU compared to minimal wage: AWU repayment}

The effectiveness of labour force in agriculture in Berati Region is very low. Work in Agriculture is paid less than the minimal wage of all farm typologies. 
Referring to the table, $85 \%$ from the Poly Culture for Market farm type, 45\% from the Self Sufficiency farm type, $79 \%$ from the Livestock farms, 44\% from the Fruit Trees Diversified Farms, 84\% from the Arable Crop Market typology, do have 2-3 working force, and so on.

\subsection{Farm size structure and number of plots per farm}

The average farm size for Berati region is about 1.4 ha with a distribution among clusters as shown in Figure 31 .

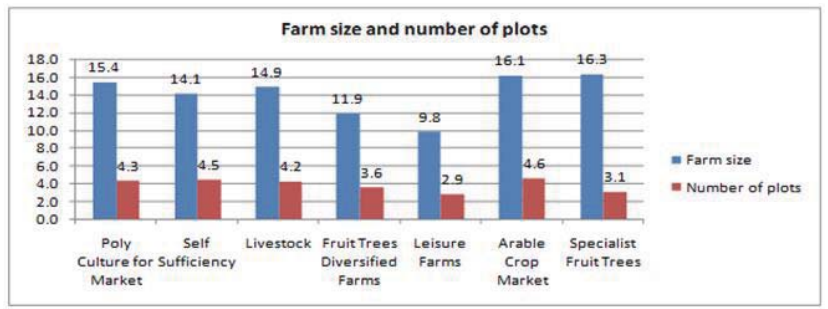

Figure 2. Average farm size (dyn) (acres) and average number of plots per farm

Hence, the variation between different typologies is very large. According to survey, the data show that farms belonging to Specialist Fruit Trees farm type, are the largest (almost $1.63 \mathrm{ha}$ ), followed by the Arable crops for Market with around $1.61 \mathrm{ha}$, Poly-culture for Market with $1.54 \mathrm{ha}$, and so on. Leisure Farms represent the smallest one, with $0.98 \mathrm{ha} / \mathrm{farm}$.

The limited average farm size and the number of plots by farm type is one of the most important problems of Berati agriculture sector. The level of fragmentation, which is important, is present in all farm types of the region. Arable crop for market farm type is the more fragmented one, $16.1 \mathrm{dyn}$ acres/farm and 4.6 plots/farm.

Taking account of the small and too fragmented farm, in order to increase production and productivity, there are two main problems to be taken into consideration: a) farm orientation towards intensive activities and b) Input support.

\section{Analysis of Farm's Economic Performance - Case of Berati Region}

Farms in Berati region continue to be over-populated in terms of household members and continue to be over-populated in terms of labour forces. The main characteristic of the agricultural farms in this Region is the domination of the family labour. About $90 \%$ of the farms satisfy their job needs from their family members. The Berati region is characterized by the presence of minimum size farms (1.26 ha) varying between different typologies from 0.98 ha to 1.63 ha of land. Current situation offers little opportunity for full-time employment on the farm.

Table 2. Income Structure By Farm Typologies in Berati Region (ALL)

\begin{tabular}{|lcccc|}
\hline Farm Typologies & $\begin{array}{c}\text { Net Income } \\
\text { per farm (FNI) }\end{array}$ & $\begin{array}{c}\text { Off Farm Income } \\
\text { per farm }\end{array}$ & $\begin{array}{c}\text { Household } \\
\text { income }\end{array}$ & $\begin{array}{c}\% \text { of farm } \\
\text { income }\end{array}$ \\
\hline 1 & 2 & 3 & $4=2+3$ & $5=2 / 4$ \\
\hline Poly Culture for Market & 777370 & 105066 & 882436 & 88 \\
\hline Self Sufficiency & 244476 & 25928 & 270404 & 90 \\
\hline Livestock & 599111 & 107642 & 706753 & 85 \\
\hline Fruit Trees Diversified Farms & 406981 & 963210 & 1370191 & 30 \\
\hline Leisure Farms & 217858 & 1181738 & 1399596 & 16 \\
\hline Arable Crop Market & 543797 & 910967 & 1454764 & 37 \\
\hline Specialist Fruit Trees & 214128 & 123700 & 337828 & 63 \\
\hline
\end{tabular}


- ALL AWU/000 produced

Based on the above indicators are identified these type of cluster for Berat district.

1. Poly-culture for market

2. Livestock

3. Leisure farms

4. Fruit trees, diversified farms

5. Specialist Fruit trees farms

6. Arable crop farm

7. Self Sufficiency

The following presentation gives synthetically the main characteristics of the typologies

\subsection{Family member structure}

The results of the study show that the family farm in Berati region consists on average of four to five people, and employment issues are in line with the national ones. Family structure in Berati region appears to be quite the same among clusters. When it comes to the number of people in working age, the overall picture varies from a minimum of 4.6 in Arable crop farms to 4.0 in Self-sufficiency farms. Members of family farms working on the farm vary from 3.1 in Poly culture farms to a minimum of 2.3 in Leisure farms. Poly culture farms are more labour intensive compared to other clusters in Berati case. The overall situation shown in the Figure 30 below represents the fact that the farm family is relatively highly populated while the number of people who are engaged in agricultural activities is relatively low.

Figure 1. Family farm structure

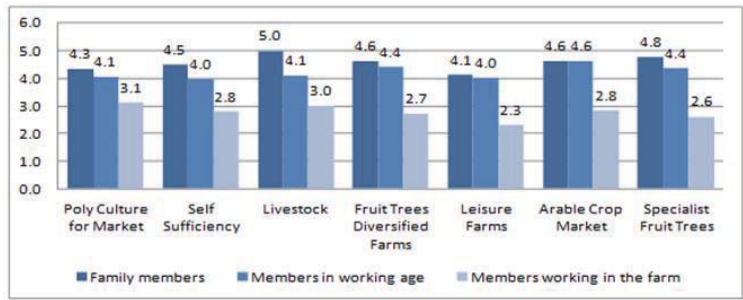

However, for various farm types the situation is not the same. Taking into consideration the farm number within each farm typology, and problems associated to each of them regarding efficiencies of activities, it can be concluded that on farm activities do not offer the potential for increasing the level of employment. This is why working-age members of farm families are forced to look for other employment alternatives.

\subsection{Farms according to labour force}

There is a major problem related to labour force and employment in the agriculture sector in Albania. Statistics show that on national level, agriculture employs over $50 \%$ of working-age and contributes to about $17.6 \%$ in GDP, but efficiency of agriculture production is very low (efficiency of agricultural sector is about 14 times lower compared to services sector or about 4 times lower compared to industry sector (INSTAT, 2012). Berati does not make any exception from this trend regarding the working force for each typology type.

Table 1. Farms distribution according workforce

\begin{tabular}{|clcccc|}
\hline No & Clusters & \multicolumn{5}{c}{ Number of Farms with } \\
& Poly Culture for Market & 7 & $>1$ and $<=2$ & $>2$ and $<=3$ & $>3$ \\
\hline $\mathbf{2}$ & Self Sufficiency & 32 & 45 & 40 & 7 \\
\hline $\mathbf{3}$ & Livestock & 4 & 53 & 21 & 3 \\
\hline $\mathbf{4}$ & Fruit Trees Diversified Farms & 54 & 34 & 10 & 26 \\
\hline $\mathbf{5}$ & Leisure Farms & 71 & 17 & 4 & 8 \\
\hline $\mathbf{6}$ & Arable Crop Market & 6 & 61 & 15 & 10 \\
\hline $\mathbf{7}$ & Specialist Fruit Trees & 38 & 46 & & 0 \\
\hline
\end{tabular}




\section{Introduction}

Organisational and administrative aspects of farming in Albania: The country is divided into 12 counties, which consist of 36 districts composed of 65 municipalities and 309 communes; what seems a very expensive and not very dynamic administration structure.

Subject of special emphasis of this study are the districts of:

- Berat; consists of two municipalities and 10 communes over 122 villages with a population of 141,944 inhabitants on 179,793 ha surface

In the following, main emphasis is put on Berat region, according to the OECD classification, it is part of the intermediate region, which stands for $45.8 \%$ of territory and $41.2 \%$ of the whole population in Albania.

The region is traversed by two main rivers, Osumi River and the Seman River, and crossed by higher mountains. Furthermore, one of them has access to national roads. The climate is typically Mediterranean: annual average temperature is 15.9 degrees C. and no real periods of frosts; but with un-typical annual precipitation of $928 \mathrm{~mm}$ per annum, with its peak in winter. Of the surface, less than $1 / 3$ or 52,919 ha is agricultural land. The migration in this county is above average, hence the average age of the population is much higher compared to Albania's average.

The rural and urban infrastructure suffers from not being connected to national main roads, and having almost no sub- road system. These lead to the fact that Berati is not one of the regions economically performing above country's average and poverty is significantly higher.

In Berati region, almost all kinds of plants, typical for Albania can be grown. It also raises all kinds of livestock typical for Albania. The agricultural production structure, output, performance and other indicators are almost like the average of Albania. A positive development is the increase of the area planted under shelters. Berati has a long tradition in the production of olives and figs; increased by $50 \%$ in recent years.

In terms of income, farmers in the region generate less from non-agriculture activities than from agriculture ones. Hence, one of the reasons may be the lower education level of people in Berat. The use of inputs, equipment, as well as other important production factors and indicators, do not significantly vary compared to the region before; with the exception that regions seem to own a greater number of tractors. Also, a difference as to other regions is that income from pensions is the main source of non-agriculture activity for the majority of farms of all groups.

Compared to the region in the past, the contribution of sheep and goats to the overall milk production is significantly higher, which might also be seen as a result of the overage population? Even if it is so, and farm grouping is hardly significant, the region seems to have an advantage in putting more emphasis on animal husbandry generally, and on milk production from both cattle and sheep, particularly.

Compared to the region in the past, all groups of farms in Berat have a much higher rate of self-re-financing agriculture by agricultural income sources of households/families; again, it may be a result of the higher average age of the population. Hence, the subsistence level is higher. This affects farm viability negatively. Thus, not surprisingly the poverty level is high and makes people more dependent on farm income.

\section{Analysis of the Regional Farm Typology}

The main source of information for our study was:

- survey conducted with farmers of Berat district, to estimate and value rigorously according to the methodology of sample selection (276 questionnaires)

- data provided through official sources (District Statistics, INSTAT, MoAFCP)

- consultation with fields expert

- similar studies conducted in this field

Farm typology is determined based on the following indicators:

- $\%$ of sold production / total production.

- $\%$ of watered surface / total surface

- $\%$ of livestock production / total livestock production

- $\%$ of agricultural production / total agricultural production

- \% of orchards production / total agricultural production

- Costs / production

- $\%$ of cropped surface/ total area

- Income outside the farm / Total income 


\title{
Assessing Farm's Performance by Farm Typology in Albania
}

\author{
Assoc. Prof. Maksim Meço \\ Assoc. Prof. Arif Murrja \\ PhD. Gentian Mehmeti \\ PhD. llir Tomorri \\ Assoc. Prof Ina Pagria
}

Doi:10.5901/ajis.2016.v5n3s1p288

Economy and Agribusiness Faculty, Agricultural University of Tirana, Albania

\section{Abstract}

During the economic transition the agricultural sector of Albania has changed significantly. This process continues parallel with global trends of periods of relative consolidation. The diversity of farm types is increasing in terms of both their production structure and production organization. Even though the farms are still small in terms of the average size, there is an increasing tendency of fallow land, due to emigration and migration of the rural population. This is mainly due to traditions, because households composed of several families use greater parts of farm land for subsistence. Farm size and fragmentation - Albania has a very large number of farms per unit surface area compared to other countries in the EU. The size variation differs according to regions: In average it is as follows: -higher in Western and South-Eastern Albania - in Fier 1.64 ha / farm; in Korçë 1.48. - smaller in Northern and NorthEastern regions -in Kukes 0.62 ha / farm. According to official statistics the size of farm plots increased from 0.20 ha plots in 2000 to 0.26 ha in 2011; which is equal to nearly $30 \%$ in a decade. But the total average size of field plots, in general is still too small to justify the intensification of production by replacing hands with machines. The crop pattern and crop rotation schemes significantly affect farm efficiency; it is dominated by wheat, corn, hay, vegetables, beans, potatoes, and orchards; the latter has a significant trend in favour of nut plants; while the cultivation of cotton, sugar beet, tobacco, rice, rape-seed, etc. is almost at a standstill in Albania. These changes result from: -farmers' freedom in decision making according to market signals; -inefficient state support systems aiming at revitalising promising markets, which also led to: *a destruction of the processing industries for tobacco, cotton, rice, vegetable oils, sugar; *the loss of traditional export markets; "misallocation of financial resources. The transition from a central, planned economy to a market economy led to a general production fall in Albania, including agriculture. The specific contribution of agriculture to the GDP went down from $54.6 \%$ in 1995 to $28.1 \%$ in 2000 , and has stabilised at this level, while the sector growth is estimated by about $3.6 \%$ per annum. Nearly $48.7 \%$ of the population in 2012 lives in rural areas where agriculture is the main source for both subsistence and income. In general, the cropping area for annual cultures decreased, except for wheat, vegetables and potatoes, while the area for forage as well as fruit trees increased. Actually, half of the cultivated cropping areas consist of fodder crops, which constitute also the high share of subsistence farming. In general, livestock is the most important agricultural sector in Albania. Its production value reached ALL 180,072 million, which equals to about Euro $1.3 \mathrm{bn}$. Animal products are a major component of self-consumption. Traditionally milk and its products in Albania are primary products also due to favourable natural conditions. Cattle are dominant in the low lands, while on the mountainous area sheep and goats. About 54.3\% of the animal husbandry output is for subsistence. The dairy sector is particularly undergoing a continuous modernisation process. Due to the high number of investments being implemented along the dairy value chain, there is a very good product range in the markets, but there is also the risk of over-capacities. This may lead to a price war: increasing milk prices for the producers but decreasing consumer prices for the processors. There seems to be a strong need for collaboration and co-operation in the sector in order to meet / keep food safety standards. This might become a major subject for Albanian Government in the on-going process of becoming a EU member. Annual average milk yield per cow is approximately $2600 \mathrm{l}$. These tendencies in the ruminant livestock affected meat production; these categories are stagnating while pork and poultry production started to increase during the last ten years. A niche market for Albanian farmers is lamb market on the eve of religious holidays, and for export. Also due to political influence orchards are increasing in terms of size and productivity. The output growth over the decade 2000 to 2010 is estimated about $234 \%$. Despite this significant progress, it is estimated that the surface of vineyards and pergola is still far from that of 1990 s, and because of this, the potential for export markets is not utilised. The Albanian export -import balance for agro-food commodities is negative; 1/9.5. In general, the sector's competitiveness is low due to the lack of sufficient knowledge; e.g. as how to use up-todate inputs or establish input supply and marketing co-operatives. The production systems are preconditioned by factors such as 1) Traditions, 2) Family demands, and 3.) use of surpluses and seasonal produce to generate additional cash income. Because of this, there is a large overhanging of unemployed labour force. Within the production structure on arable land, the dominating crop is winter wheat followed by corn. Among the higher value cash crops, water melons, beans and potatoes have the largest shares. Disadvantageous as to several aspects, is the almost complete disappearance of technical cultures of crop rotation over the last 20 years; e.g. sunflower or tobacco. Unfortunately; the statistical database is weak and partly inconsistent for getting realistic information about yields in $\mathrm{dt} / \mathrm{h}$ a or profitability estimates. The decline in the acreage of cash crops is the result of the expansion of food crops. 
Ministry of Economic Development, Tourism, Trade and Entrepreneurship

http://www.ekonomia.gov.al

www.ecotourism.org

http://www.akt.gov.al/en/

www.transporti.gov.al/

http://www.zhvillimiurban.gov.al/

http://www.united-albania.com/albanian-tourism-in-the-news/albanian-tourism-in-the-news.html

http://www.travbuddy.com/Albania-travel-guide-c27 
infrastructure and ending in information management so this industry could overcome its infancy stage and affect the country's economy more effectively. At the end we have to understand that this study is highly specialized in only one country and the literature on the field was limited to the government. Hence the actual situation in the Albanian tourism is not bright its future for sure is.

\section{References}

Albania: Guide to its Natural Treasures, ECAT-Tirana, Tirana 2000

Albania: The Bradt Travel Guide (Bradt Travel Guides Ltd), 2005

"Albania: Integrated Coastal Management and clean-up Program: site management framework" SIM-Spa and iMed for World Bank 2005. Albinvest (2016),"Albania Your Investment Destination", Gent Grafic, Tirana

ANIH(2005), http://www.anih.com.al/english/info.asp?idcontent=51\&id=48\&p=1,"Invest in Albania", Visited on 19th of January 2016.

Bernard R (2000), "Social Research Methods:Quality and Quantitative Approaches, Thoudand Oaks, London

Balaguer \& Cantavella-Jorda (2002) J. Balaguer and M. Cantavella-Jorda, Tourism as a long-run economic growth factor: The Spanish case, Applied Economics 34 (2002), pp. 877-884.

Burns, P. and Holden, A. (1995) eds, Tourism: A New Perspective. Harlow

Burkhart, A.J. \& Medlik, S. (1981) Tourism: Past, Present and Future. London: Heineman

Cowen, M. \& Shenton, R. (1996) Doctrines of Development, Routledge, London

Dunn \& Dunn (2002) H. Dunn and L. Dunn, People and tourism: Issues and attitudes in the Jamaican hospitality industry, Arawak Publications, Kingston (2002).

Elliott, J (1998)The Curriculum Experiment. Meeting the Challenge of Social Change, Open University Press: Milton Keynes.

Eugenio-Martín \& Morales (2004) Eugenio-Martín, J. L., \& Morales, N. M. (2004). Tourism and economic growth in Latin American countries: A panel data approach. Social Science Research Network Electronic Paper.

Ghauri and Gronhaug (2002), "Research Methods in Business Studies, Pearson Education, Harlow

Goulet, D. (1992), "Ethics and development: a development ethicist at work", National Geographic Research \& Exploration, Vol. 8 No.2, pp.139-47.

Gursoy \& Rutherford (2004) D. Gursoy and D.G.R. Rutherford, Host attitudes toward tourism: An improved structural model, Annals of Tourism Research 31 (3) (2004), pp. 495-516.

Hazari \& Ng (1993) B.R. Hazari and A. Ng, An analysis of tourists' consumption of non-traded goods and services on the welfare of the domestic consumers, International Review of Economics and Finance 2 (1993), pp. 3-58.

INSTAT (2015), "Economic Indicators of Albania", Tirana Press, Tirana

Jenner \& Smith (1992) Jenner, P., \& Smith, C. (1992). The Tourism industry and the environment. The Economic Intelligence Unit, Special Report, no. 2453, London, UK.

Liu \& Var (1986) J.C. Liu and T. Var, Resident attitudes toward tourism's impact in Hawaii, Annals of Tourism Research 13 (2) (1986), pp. 193-214.

Lonely Planet Guide to Eastern Europe (and web version for Albania, from Lonely Planet, UK) 20011.

Long, Perdue, \& Allen (1990) P.T. Long, R.R. Perdue and L. Allen, Rural resident tourism perceptions and attitudes by community level of tourism, Journal of Travel Research 28 (1990), pp. 3-9.

Milne (1990) S. Milne, The impact of tourism development in small Pacific island states: An Overview, New Zealand Journal of Geography 89 (1990), pp. 16-21

Nash, D. (1981). Tourism as an Anthropological Subject. Current Anthropology, 22 (5): 461-481.

Pearce (1985) D.G. Pearce, Tourism and environmental research: A review, International Journal of Environmental Studies 25 (1985), pp. 247-255.

Sharpley, R. (2002): The Consumption of Tourism.Tourism and Development: Concepts and Issues.Richard Sharpley and David J. Telfer (Der) ss. 300-318. Clevedon, Cahnnel View Publications.

Sinclair (1998) M.T. Sinclair, Tourism and economic development: A survey, The Journal of Development Studies 34 (1998), pp. 1-51

Syriopoulos (1995) T. Syriopoulos, A dynamic model of demand for Mediterranean tourism, International Review of Applied Economics 9 (1995), pp. 318-336.

TTI (Travel \& Tourism Intelligence) Country Reports (Al)

Toward a Strategy for Culture Tourism and Ecotourism Development."Ministry of Economic Development, Tourism, Trade and Entrepreneurship. September 2016

Toward a Strategy for Culture Tourism and Ecotourism Development." Ministry of Economic Development, Tourism, Trade and Entrepreneurship. September 2016.

"Technical Assistance in Developing Nature-Based and Rural Tourism in Albania", unpublished consultant report conducted by World Tourism Organization experts for the United Nations Development Programme -Tirana. October 2005.

Thomas, A. (2000a) 'Meanings and Views of Development', in Allen, T. \& Thomas, A. (eds) Poverty and Development into the Twenty-first Century, Oxford: Oxford University Press.

WTO, Travel and Tourism Analyst, No. 4, 2001 by Travel and Tourism Intelligence

Internet 
Demand and Supply, also it is indispensable that the organization, collection and analysis of data and information is done through the standards of the EU.

Private and public sector involvement Tourism as an industry has to be promoted by the public sector especially in its infancy, but after a certain stage of development the private sector has to be included on this strategy and make its contribution on many levels.

Furthermore the involvement of the private sector is vital as they will be the primary source of financing and investment.

\subsection{This strategy will try to achieve}

Through the achievement of the aims pinpointed in the strategic section which aims at the Albanian tourism's full potential and the development of this sector through sustainable time period on factors such as: culture social, environmental, economical.

This strategy will try to achieve:

$>$ The management of the sector in order to insure the long term economic growth

$>$ The management of tourism industry sub-sectors, in order to approach tourism development through the enrichment of such as natural, social and cultural factors which form the base for the development of this industry.

$>$ Supply the appropriate structure in which profit and investment would reach the highest levels

Eliminate errors and problems within the tourism sector

$>$ Achieve investment from both the private and public sector

$>$ Facilitate the investment and the operation of different businesses in this industry

$>$ Adapt to the overall national economic strategic development

\section{Summary and Conclusions}

This part brings this paper to an end by making some concluding remarks on the study of the Albanian tourism development. Thus the main aim for this dissertation was to analyze describe and discuss the Albanian tourism development it also took a slightly different approach by analysis the effect of this sector on the Albanian economy as well.

As I pointed out in my method and abstract chapters most subjects on this dissertation contribute to the bigger picture of how Albania should develop its tourism sector and how this could affect the country's economy. In a brief summery I gave an overview of the present situation of the actual Albanian tourism industry and the potential that this sector has. Furthermore I took a close look to the main challenges faced by the country and the government in general for the developed of this industry.

Based on several theories on tourism development the main terminology and theories were further analyzed. Literature on the subject as well as the advantages and limitations consisted in previous studies on this manner were analyzed and further explained. Different theorists on tourism development starting from Sinclair who analyzed the economic advantages and disadvantages of tourism development and many others that focused on his views like Eugenio-Martín \& Morales as well as Syriopoulos were mainly concerned with the effects that tourism development had on the economy. Moreover there were other theorists like Liu and Var, Long, Perdue, and Allen and Milne that have contributed to the field of tourism development but in a different prospective. They were concerned with the costs involved by adopting tourism development as an industrialization and development strategy.

Further analysis on the literature detected limitations especially on the methods of development as in the ways in which the countries should carry out tourism development and the actions that need to be taken on order to succeed in this industry. On this basis I have supplied and analyzed the main challenges that the county faces in order to develop the tourism sector. As we sow the challenges were many starting form infrastructure and ending with information management. In order to overcome these challenges the government and other analysts supplied a strategy which I have described in details where tourism products are used in order to develop an industry that it has been said is in its infancy. I in this prospective my study shows that a strategy is not enough and further actions are needed in order to develop the tourism sector. On this basis a detailed discussion was developed in order to understand in detail the actions needed to be taken from the government and the national in general at the same time, in order to develop the tourism sector successfully. This discussion was based on actions that were needed to be taken in any particular fields starting from 
Through the increased economic potential of the country and near the potential of EU entrance Albania expects to be visited more from this segment of the market. The annual increase of the foreign direct investment makes this market highly attractive ${ }^{5}$.

Table 4. Tourists attracted form "Business and Conference" 2016

\begin{tabular}{||l|c|c|c||}
\hline \hline Periods of Time & Short term & Medium term & Long term \\
\hline Foreign daily $\mathrm{T}$ & 30000 & 40000 & 80000 \\
\hline
\end{tabular}

Source: Toward a Strategy for Culture Tourism and Ecotourism Development." Ministry of Economic Development, Tourism, Trade and Entrepreneurship. September 2016.

\subsection{Pre conditions for the implementation of the strategy}

In order to achieve the objectives that this strategic project is going to address there are some pre conditions that need to be fulfilled.

\subsubsection{Infrastructure}

Infrastructure is one of the biggest obstacles for the development of the tourism in special destinations around Albania. The most important airport Rinas which is located within the capital Tirana and the second biggest city Durres has to reach the international levels. In the future is necessary a second airport in the north as this part of the country is also called the Albanian Riviera and has to absorb most of the flux of visitors. This second airport will be mostly used for the charter flights which in today's standard are the base for development of tourism as an industry.

Indispensable is the organization and development of an efficient rubbish collection and cleaning entity which will help the tourist attractions to be more attractive and clean at the same time.

\subsubsection{Land-law problem resolvance}

The improvement of old and introduction of new lows on property rights and land so the legal systems won't stop the strategic development of this industry

\subsubsection{Tourism laws and regulations on regional and national levels.}

Contemporary formulation of laws is indispensable and regulations on tourism so the governmental organisms can apply and improve the industry.

\subsubsection{Law and order}

Law and order are indispensable and fundamental for the development of tourism as an industry; this applies especially on fields of construction permits and pollution.

\subsubsection{Clear responsibilities on all governmental levels}

Clear description of all responsibilities for all the institutions involved in the tourism arena.

\subsection{Information system}

The effective improvement of the information system so there is clear information on economic levels concerning

${ }_{5}^{5}$ Toward a Strategy for Culture Tourism and Ecotourism Development.Ministry of Economic Development, Tourism, Trade and Entrepreneurship. September 2016. 
There is high connectivity with the main European cities through most of the methods of transportations including here (sea, air, and land). Relying on the World Tourism Organization "Sun and Beach" tourism until now is one of the markets with the highest demands in the whole world.

Table 1. Tourists attracted form "Sun and Beach" 2016

\begin{tabular}{||l|c|c|c||}
\hline \hline Periods of Time & Short term & Medium term & Long term \\
\hline Home tourists & & & \\
\hline Arrivals & 395.000 & 430.000 & 515.000 \\
\hline Nights stay & 2.834 .000 & 2.825 .000 & 2.875 .000 \\
\hline$\%$ of all arrivals & $54 \%$ & $51 \%$ & $38 \%$ \\
\hline$\%$ of all nights stay & $63 \%$ & $57 \%$ & $45 \%$ \\
\hline
\end{tabular}

Source: Toward a Strategy for Culture Tourism and Ecotourism Development." Ministry of Economic Development, Tourism, Trade and Entrepreneurship. September 2016.

Table 2. Tourists attracted form "Sun and Beach" 2016

\begin{tabular}{||l|c|c|c||}
\hline \hline Periods of Time & Short term & Medium term & Long term \\
\hline All Ethnics & & & \\
\hline Arrivals & 200.000 & 210.000 & 230.000 \\
\hline Nights stay & 1.345 .000 & 1.330 .000 & 1.380 .000 \\
\hline$\%$ of all arrivals & $43 \%$ & $11 \%$ & $42 \%$ \\
\hline$\%$ of all nights stay & $44 \%$ & $77 \%$ & $46 \%$ \\
\hline
\end{tabular}

Source: Toward a Strategy for Culture Tourism and Ecotourism Development." Ministry of Economic Development, Tourism, Trade and Entrepreneurship. September 2016.

\section{5 "Special Interest" Tourism (product)}

Albania has a reputation as one of the few undiscovered countries in Europe in which tourist can still discover unseen secrets relying on wild nature and cultural diversity.

This product is one which has the most potential out of all as most of the international tourist that visit the country in the last years have all targeted this segment of the market ${ }^{4}$.

This graph will show all the main aspects of this product.

Table 3. Tourists attracted form "Special interest" 2016

\begin{tabular}{|l|c|c|c|}
\hline \hline Periods of Time & Short term & Medium term & Long term \\
\hline Foreign tourists & & & \\
\hline Arrivals & 15000 & 69000 & 313000 \\
\hline Nights stay & 80.000 & 400.000 & 1.640 .000 \\
\hline$\%$ of all arrivals & $7 \%$ & $25 \%$ & $58 \%$ \\
\hline$\%$ of all nights stay & $6 \%$ & $23 \%$ & $54 \%$ \\
\hline
\end{tabular}

Source: Toward a Strategy for Culture Tourism and Ecotourism Development." Ministry of Economic Development, Tourism, Trade and Entrepreneurship. September 2016.

\subsection{Business and Conference Tourism (Product)}

This sector specializes on business tourists. Albania has all the conditions to accommodate these types of tourists including here hotels, conference rooms, relaxation atmospheres which make their stay more efficient and reliable. Most of the business centres build in the major cities offer modern business facilities indispensable for business tourists.

${ }^{4}$ Toward a Strategy for Culture Tourism and Ecotourism Development.Ministry of Economic Development, Tourism, Trade and Entrepreneurship. September 2016. 
specialised tourism travellers. The main objective here will be the upper middle class of the European, North American population. This demographic segment represents a potential investor that would be prepared to pay for the unique and unprecedented tourism experience. One of the most strongly strategic points in the Albanian tourism will be giving the opportunity to the tourist to visit as much attractions as possible as the geographic position is perfect for these activities In order to keep authenticity the core values and traditions will be caped and enriched in both business terms and individual as well. This will attract more visitors and will be able to enrich more the relationship between the population and the tourists which will eventually lead to more income for the community. In order to keep a constant tourism development the tourists should repeat their visits or advertise the benefits of tourism in terms of mouth to mouth advertising to their friends and relatives so the demand will always be high.

\subsection{Overall strategy}

Strategically the Albanian tourism will develop organically as an authentic destination relying on his rich cultural, historical and natural factors according to most of the Albanian Ministry officials. The best international cultural practises involved in tourism strategies will be studied and worked on so they can adapt cultural tourists. In this section I am going to describe the main tourism products and the preconditions that are needed for the implementation of these strategic tourism products.

The strategic development according to Dr.Noli will be based on three main tourism products namely:

$>$ Sun and Beach

$>$ Special interest

$>$ Business and conference

These tourism products will be supplied to the international tourism market and will be backed up by an advanced marketing, an action plan and a high involvement of human resources which will secure its long term prosperity. Also for the right development of this strategy the government support is crucial. The government should direct and protect all the councils, the private business and the travel agencies in order for this strategy to be successful.

\subsection{Strategic tourism products}

Overall there are a number of tourism products that exists in these industry the Albanian tourism industry will focus their strategy on three main once. Most of the products are characterized by:

$>$ Activities (Business, sports)

$>$ Motivation (Holidays, treatments)

$>$ Price (niche or mass)

Albania is just starting to develop both internal and international tourism these products are essential for its development. They are likely to create a base where all the industry will focus. This strategy suggests that based on these products (which I am going to mention further on)the hole industry will change as all the finance, marketing, HR, infrastructure, government policies, information systems, private businesses will back up the well functioning and development of these tourism products with directions from the ministry of tourism ${ }^{1}$.

\section{4 "Sun and Beach" Tourism (product)}

Albania is well positioned in both the national and international tourism market as a holiday destination with considerable holiday prices based on the assumption (value for money) in the Mediterranean tourism market².

The country has an attractive Riviera in the east side of the Adriatic Sea characterised by beautiful sea sides, clear waters and attractive harbours. The country is the second in Europe after Spain for sunny days approximately 300 out of 360 days a year ${ }^{3}$. The holiday seasons are long based warm weather beautiful atmospheres.

\footnotetext{
1 Toward a Strategy for Culture Tourism and Ecotourism Development.Ministry of Economic Development, Tourism, Trade and Entrepreneurship. September 2016.

2 Toward a Strategy for Culture Tourism and Ecotourism Development.Ministry of Economic Development, Tourism, Trade and Entrepreneurship. September 2016.

${ }^{3}$ www.akt.gov.al
} 
and interact with other people and places. In short we can say that tourism is a social phenomenon which involves the movement of people to various destinations (Richard Sharpley, David J.Telfer, 2002).

\section{The Methodology and Model}

This research project is based on secondary research (literature review) and primary research (interviews, conversations). As Ghauri and Grounhaug (2000) argue that the main advantage of primary data is that it is useful for a specify project. In this project opinions and beliefs can be analysed through asking the right question to the right people.

\subsection{Primary research}

As Bernard (2000) argued that key informant interviewing works well in a project where the research is dealing with high ranked managers or elite members of community as it is the case on this project where these are chosen on the basis of their characteristic specialised knowledge.

The essence of this project required key informant interviews as the literature on the subject was not enough to analyse and understand in detail the development of Albanian tourism.

My main focus is to understand the ways in which Albanian tourism is going to develop.

Developing an industry is not an easy task and it cannot be done by individuals the only institution that can carry such a big responsibility is the government.

In most of the cases governments construct national tourism strategies and try to implement them in a described period of time. Some of the most tourism oriented economies like Turkey, Greece and Croatia have adopted this views decades ago. So I decided that to better understand Albanian tourism the only possible solution was to approach the right institutions involved with this industry.

In depth interviews more precisely semi structured interviews. These were carried where specific key questions were conduced within a set of skeleton questions. I realized that in order to get the most out of my interviews I had to prepare some close questions as well in order to give more alternatives and gain specific results from my interviews.

Four main interviews were carried with:

Minister of Economic Development, Trade and Entrepreneurship: Prof. Dr. Milva Ekonomi

Director of marketing and promotion in the national tourism agency: Dr. Ardit Collaku

Director of tourism and national culture: Dr. Mensur Bytyci

Director of tourism strategy: Dr. Elton Noli

\section{The findings}

This strategy was developed from the Albanian government in association with the German government. I will try to analyze the most important aspects of this strategy and its contribution to the Albanian tourism development.

\subsection{The strategic position}

\subsubsection{The strategic position of Albania's tourism sector}

According to Dr. Elton Noli the Strategic Director in the Ministry, Albania is a secure tourist destination characterized by a mixture of cultural and natural attractions which are internationally recognized. Within this small geographical location tourism has been managed in a way that all the recourses include here natural and social have been adapted to the needs of the global tourist (customer)". Albania will position itself as an attractive destination for the tourists that require a unique experience which is characterised by highly attractive and authenticable destinations including both cultural and historical. The country will position itself in the tourism arena as a tourism destination that needs to be discovered with the logo "Albania - Yours to explore!"

With its main product the "discovery of Albania" the tourist should be able to absorb and discover the history, nature, archaeology, culture of living, national foods and the population traditions of this amazing country . After leaving the country the tourists would be impressed by the diversity of nature and culture as well the welcoming people of the land of eagles.

According to Dr E.Noli Albania will attempt to specialise and position itself in welcoming unexpected and 


\subsection{Why tourism?}

Bank of Albania studies indicates tourism is responsible for $6 \%$ of GDP. Tourism income generation annually is between US\$600 million to US\$1 billion in revenue. The governments hope lies in their new project called "Strategy of Albanian Tourism Development" which will be analyzed further on this project.

Other factors that reinforce the importance of this industry in the Albanian region are:

1. The absence of an effective inbound industry serving the foreign tourism market at present.

2. The present historic and archaeological pattern of travel around the country.

3. The presence of a latent inbound operator capacity capable of handling a recovery in the market.

4. Financial resources amongst historical operators to reinvest following pyramid losses are limited and will retard market growth and product development.

Albania has a great development potential when it comes to tourism. Most of the attractions including both cultural and natural have high potential and would have attracted high levels of visitors if they were advertised properly to the right audiences Albania could be positioned similarly as those countries which have high levels of tourism attractions and are geographically small so can build a admired position in the international tourism arena.

However for Albania now is important that the tendencies in the tourism preferences are changing. Culture and adventure as well as ecotourism are considered to be fastest growing markets in the global tourism arena. Their popularity shows that change is accruing. Passive based holidays which started to dominate the market in the 70s are losing market share to theme based holidays which focus in activities of high interest especially adventure and exploration which characterize the Albanian tourism .

Traditional tourism involving "Sun and Beach" still remains one of the largest segments in the international tourism market as it has a normative growth of $2 \%--4 \%$ a year .In the mean time the market on cultural tourism is increasing in some unprecedented levels, its market share is estimated between 60 to 70 million people, with a potential growth of 15\% a year until 2018. Adventures tourism in the other hand is another segment of this market but with a fast growing potential as it has approximately 5 million tourists overall and a growth of $20 \%$ every year. At the end we have natural tourism this segment has an orientation on the exploration of natural resources. In the international tourism market this segment involves $50 \%$ of the overall tourism market and has shown high levels of growth in the last decade .

Our neighbour countries like Greece, Turkey and Croatia are focused on the tourism market of "Sun and Beach" by doing this they have increased the competition in this market heavily. Albania has a unique opportunity to differentiate itself from its neighbours so it separates itself from heavily competitive market with declining potential and low profit margins . Furthermore a tourism which focuses on independent tourists interested in local communities, natural resources and culture has shown to be from 5 to 10 times more profitable in terms of dollars spend from tourists compared to tourism based on "Sun and Beach". What makes Albania a unique attraction is the ability to have a big amount of attractions in a relatively unique aspect and geographically close to each other.

As in terms of its unique market position what it might have started as a necessity it stands now strong and identified in the international tourism market arena. It seems like Albania is situated in ideal position to fulfil the always changing needs of a tourism market based on culture and nature.

\section{Literature Review}

Tourism still remains a term that is subject to diverse interpretations including wide verities of definitions (Richard Sharpley, David J.Telfer, 2002). This reflacts in part the multidisciplinary nature of the topic and in part the abstract nature of the tourism concept (Burns \& Holden, 1995; 5). Despite of all the difficulties tourism can be defined as the activity or process that allegedly acts as catalyst of development (Richard Sharpley, David J.Telfer, 2002). Burkhar and Medlik classify two main groups of tourism definitions (Burkhar \& Medlik, 1981;41-3):

Technical definitions - where they define a tourist as someone that who travels for more than 24 hours outside their normal country of residence

Conceptual definitions - where they argue on the basis of (Nash, 1981) that tourism is simply the activity undertaken by a person at leisure who also travels

Even though this definition tries to explain tourism in its route it has been argued that it takes divers extremes to the main concept. We have to understand that tourism is primarily a social activity (Richard Sharpley, David J.Telfer, 2002). If people wouldn't have neither the desire nor the ability to travel tourism wouldn't exist (Richard Sharpley, David J.Telfer, 2002). Thus tourism is an activity that involves individuals who travel within their own country or internationally 


\title{
Developing Albanian Tourism
}

\section{Lorisa Ylli}

Email: lori.ylli@gmail.com

\section{Doi:10.5901/ajis.2016.v5n3s1p279}

\begin{abstract}
This paper examines the development pattern of Albania's tourism and the effect that this industry will have in the country's economic development. I will attempt to demonstrate that tourism is an indispensable industry in the developing countries like Albania furthermore if it develops through a precise strategy with the government and other institutional support it can contribute to the development of the country. Firstly I will give a general overview of this industry and its capabilities which are relevant in understanding Albania's tourism and its actual situation. In the second part I will describe the strategy that will be implemented by the Albanian government in the tourism sector until 2021 and analyze its overall contribution to this industry.
\end{abstract}

Keywords: Tourism, Economy Growth, Albania

\section{Introduction}

In this project Tourism development will be analyzed and discussed within multiple levels including strategically, its effect on economic development and at the practical level all focusing on the main example Albania.

The main objectives of the project are:

1. Understand tourism development from an industrial and business prospective

2. Detect the challenges faced for the development of this industry

3. Find the effect of government on industrial development

4. Analyze strategies used by the Albanian government (On Tourism)

5. Analyze the effect that tourism development has on economic development

6. Discus the actions which might help the development of Albanian tourism

Motivated by the fact that Albania is a developing country and due to my present study on "Modern Business on Comparative Prospective" specialized on national competitive advantages as well late industrializing countries I thought that tourism development would be one of the major factors that would contribute to Albania's national competitive advantage and as a consequence to future economic development. In order to do this I had to analyze most of the theories on tourism development and at the same time apply a practical case which in this case is Albania. This was what motivated me to undertake this topic.

\subsection{Tourism to Albania}

We can call the actual time as the infancy of the Albanian tourism for the main reason that the country had its first glimpse of international tourism in the $90 \mathrm{~s}$ after the fall of the communist regime that ruled the country for 50 years. Since the 90s it was difficult for the country to establish any kind of industry as in the case of tourism the whole industry was based on internal tourism. Albanian government officials suggest that the development of an internationally competitive industry is possible as $80 \%$ of the coastline is still virgin and untouched by the human hand. Moreover government officials argue that Albania has a strong underlying product with highly saleable potential in the world tourism market.

According to the Albanian government in 2016 the number of foreign visitors reached 1.6 million including ethnic Albanians. The last summer the number of foreign visitors reached 900.000 which indicated that the country was experiencing a tourism "boom" where there was an increase of $35 \%$ of tourism visitors compared with the previous years and from these $92 \%$ were European, 5\% American, 2\% Asian and 1\% other nationalities. According to World Travel \& Tourism council the contribution of tourism in GDP actually is around 3.8\% but from 2016 until 2021 this contribution is estimated to be around $7.5 \%$.

The infrastructure is in constant improvement. In the last 15 years roads highways, international air services were privatized. Moreover the government is implementing always new policies in favor of industrial tourism expansion. 
shaft: "Shaft is shown on the scheme."

axis: "Axis is presented."

link: "Link is a part of the pair."

shaft: "Shaft consists of (is constituted of) the body of pins."

axis: "Axis is called a part that does not transmit torsional moment."

\section{Conclusion}

Relating to a given text from the presented field a study of the vocabulary can be done where it can be seen as to how these three types of vocabularies enter e relationship with one another. Of course, here the prime position is held by the terminological vocabulary, which can appear formalized through the connections in which the terms enter with one another, while the second position is occupied by the vocabulary that marks the interior features of the concepts marked by the terms, which are of particular importance to present them as part of the definitions. These features can also be derived directly from the text, but they can also be derived in an intuitive manner. These key terms can be derived directly on the basis of their value in the system.

Component elements of phrase terms appear as internal connections between them, and as such they should be looked at in relationship to each other. Thus, eg in rrotë e dhëmbëzuar (dentated wheel), the defining element emerges as an internal connection of the defined part, marked from the element: rrotë (wheel). It can also be said for other cases: rrip i dhëmbëzuar (dentated belt) i.e. i dhëmbëzuar (dentated) in relation to: rrip (belt), boshti i dhëmbëzuar (dentated shaft) in relation to: bosht (shaft). This means that the defining elements of the phrase terms should also be given separately, by connecting them always after the defined element.

\section{References}

Beer, F., etc.: "Vector Mechanics for Engineers Statics", McGraw-Hill, New York, 2004.

Buckch, H.: "Getriebewörterbuch- Dictionary of mechanisms", Bauverlag GmbH-Wiesbaden und Berlin, 1976.

Duro, A.: "Termi dhe fjala në gjuhën shqipe", Tiranë, 2009.

Felber, H.: "Terminology manual", UNESCO and Infoterm, Paris, 1984.

"Fjalor i termave themelorë të mekanikës", Tiranë, 2002.

Karaulli, P.\&Çelo, G.:"Mekanika e aplikuar në makina l", Tiranë, 1974.

Kurti, Ç.: "Fjalor politeknik anglisht-shqip", Tiranë, 1991.

Norton, R.:"An Introduction to the Thynsesis and Analysis of Mechanisms and Machines" Massachusetts, 2004.

Schwarz, C.: "The Chambers Dictionary", Edinburgh, 1993.

Wüster, E.: "Einführung in die allgemeine Terminologielehre und terminologische Lexikographie", 3. Auflage. Romanistischer Verlag, Bonn, 1991. 
be distinguished:

2.1 Direct connections, as internal organic connections, where the defining elements emerge as features of the concepts of terms, as can be seen in the following examples:

In Albanian:

Hallkë - lidh, lidhet, rrotullon, rrotullohet, transmeton.

Aks - rrotullohet, kryqëzohet, mbështet, lidh, lidhet.

Bosht - rrotullon, rrotullohet, mbështet, transmeton (moment përdredhës).

In English:

link - connects, (is connected), rotates, turns (is rotated) transmit (convey).

axis - turns, (is rotated), is crossed, supports (bears),

links, is linked.

shaft - rotates, turns, support, transmits.

Indirect connection, where the determining element is the secondary feature of the concept of the term.

In Albanian:

Hallkë - zë pozicion, vendoset (vendos), zhvendos, lëviz,bart,etj.

Bosht - zë pozicion, vendos lëviz, bart.

In English:

link - is located, is fixed, take position, displace, move, bear

shaft - is located, move, rotate (turn), bear.

2.2 The free connections, in which the term comes with the usual vocabulary. As a general rule, the term is more or less connected with each unit, starting with: është, ka, quhet (is, has, is called).

In a summary we can present with few examples all three types of connections:

1. Internal connection:

In Albanian:

Hallkë: "Hallka A lidhet me hallkën B."

Bosht: "Boshti A rrotullon boshtin B."

Aks: "Aksi A mbështet detalin B."

In English:

link: "Link A is connected to link B."

shaft: "Shaft A rotates shaft B."

axis: "Axis A supports part B."

2. Indirect connection:

In Albanian:

Hallkë: "Hallka zhvendoset nga pozicioni A në pozicionin B."

Bosht: "Boshti zhvendoset nga pozicioni A në pozicionin B."

Aks: "Aksi zhvendoset në drejtimin e dhënë."

In English:

link: "Link removes from position A to position B."

shaft: "Shaft removes from position A to position B."

axis: "Axis removes into the given direction."

3. Free connection:

In Albanian:

Hallkë:"Hallka paraqitet në vizatim."

Bosht:"Boshti paraqitet në skemë."

Aks: "Aksi paraqitet në figurë."

Hallkë:"Hallka është pjesë përbërëse e çittit."

Bosht:"Boshti përbëhet nga trupi dhe pernat (qafat)."

Aks: "Aksi është detal që nuk transmeton moment përdredhës."

In English:

link: "Link is shown on the drawing." 


\title{
Proximity Stages of the Semantic Connections of Terms of Applied Mechanics to Those Terms and Other Types of Vocabulary
}

\author{
Prof. ass. Dr. Sadete Pllana \\ University of Prishtina "Hasan Prishtina", Faculty of Economics, Republic of Kosova \\ Email: sadete.pllana@uni-pr.edu
}

Dr. Dipl. Ing. Gani Pllana

University of Prishtina "Hasan Prishtina", Faculty of Mechanical Engineering, Republic of Kosova Email: gani.pllana@uni-pr.edu

\section{Doi:10.5901/ajis.2016.v5n3s1p276}

\begin{abstract}
These connections have an interest to be studied from the side of the conceptual volume of expression, which are put in relationship from the form, for the respective expression of the conceptual volume, from the widest to the narrowest one, from where three forms of terms get distinguished: base terms, which become the object of this study: base terms (zinxhir, mekanizëm/chain, mechanism), foundation term (mainly two worded) (mekanizëm katërhallkësh/four - bar mechanism and peripheral terms (mainly more than twoworded) (mekanizëm katërhallkësh i çernieruar/hinged - four - bar mechanism). This classification directs the studies in the field of the terminological vocabulary of the respective field, in subordination (depending) on the volume of the concept, as well as from the side of the form of expression of the concept, therefore, of the term itself.
\end{abstract}

Keywords: Aplied mechanics, foundation term, peripheral terms.

\section{Introduction}

Within a scientific-technical text, as may be noted in a text of the field of Aplied Mechanics (AM) (Alb. Mekanika e Aplikuar (MA)), but also in the formalized way, the terms, by conveying a particular information, enter in relation to each other as well as with units of other types of vocabulary based on the meanings expressed by each of them. The units can create syntagmatic structure, in which the relationships are expressed directly, as, for example, boshti rrotullon (shaft rotates), aksi rrotullohet (axis turns) or aksi mbështetet (axis is supported), rrota rrotullon (wheel rotates) or rrota rrotullohet (wheel turns), but they can also form on the basis of conceptual relations, as, for example, çift (pair) and lidhje (linkage), hallkë (link) and element (element). On links built between lexical units with each other, different degrees of closeness are revealed, based on the meanings they express. So we have a semantic link of a such a narrow proximity, that they can be seen as internal organic links, wherein the defining element emerges as a feature of the concept of the defined element as, eg, ingranohet in dhëmbi ingranohet (tooth is engaged), shtyn in gunga shtyn (valvolën) (cam pushes) (valve), lëkundet in bilancieri lëkundet (rocker swings), rrotullohet in manivela rrotullohet (crankshaft turns), transmeton in boshti transmeton (shaft transmits), boshti rrotullon (shaft rotates), boshti rrotullohet (shaft turns), aksi rrotullohet (axis turns), mbështetet in aksi mbështetet (axis is supported).

\section{Concept Features, Expressed by Defining Unit}

In the most general case the features of the concept expressed by the defining unit, become the identifier of the concept itself marked by the respective term. Thus, for example the feature lëkundet (swings, rocks), reveals the identity of bilancierit (rocker), rrotullon (rotate) and rrotullohet (turns, is rotated) the features of the wheel, etc..

As it is obvious, more direct connection are placed between the terms and the non-terminological textbook vocabulary, within which the features of concepts expressed by the terms are also revealed. In this case we are dealing with internal connections, which are expressed in the constraints of the defining element of connectivity, where it appears that its combining ability is limited to certain terms like rrotullon with: bosht, rrotë, hallkë (Engl. shaft, wheel, link), etc..

Looking at the connections in which the term enters with other units of non-terms, three stages of connections can 
fact that Albania did not go through the historical stages like feudalism and capitalism. Reflecting the different stages in the course of history have been established different practices in different areas. The 50-year-old socialist system in the field of construction introduced new traditions and changed the contents in accordance with the ideological and political goals. The changes that the settlements uderwent during this time were both quantitative and qualitative. Quantitative changes consisted in increasing the number of buildings in rural areas thereby creating big rural centers tantamount to the city. Qualitative changes, consisted in an effort to adapt new community functions, according to political criteria and in accordance with the typology of the village. For this process, the necessary economic factor was government ownership of the land. As regards the socialist organization of state agricultural co-operatives, rural residential areas are generally characterized by agrarian and mixed settlements, but some villagers made a living working in industrial sectors (mining or wood processing that had been close to their homes). The basic principle of a regulatory plan regarding a settlement was building housing units in different socio-cultural centers.

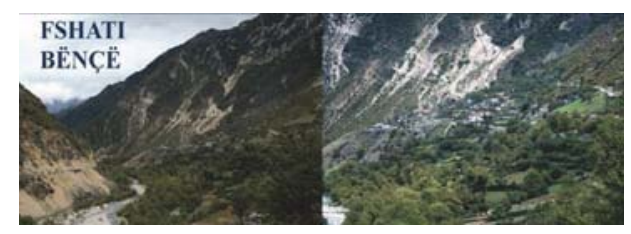

Fig. 5. The village of Bençë (Tepelena District)

\section{Conclusion}

Traditional elements were preserved more in hilly and mountainous areas, but this thing did not occur in lowland areas. Settlement setting expresses the relationship between social groups and material life conditions (natural environment and land). The types of settlements have historically influenced social life of the locals, the relationship between them and the outside world. The spread and distributed type can be found in all geographic areas of the country, as the case may be, or they may even be combined with each other. In the construction of rural settlements have been preserved traditional elements and special features according to the different areas and historic development.

\section{References}

Adhami. S. Overview of the popular culture of the area of Permet. Page 22-126. 236. GERVIS. Tiranë 2001. Adhami. Stilian. Overview of the popular culture of the area of Permet . Page 22-126. GERVIS. Tiranë 2001.

Axhemi. S. Geography of the population and of the settlements. Page 190-211. ALSA. Tiranë 2007.

Bërxholi, A., The changes in the geography of the population in the Vjosë- Ionian sea area ( demographic study), Faqe 9-15; 57-66. Tiranë 1987.

Hana, L., Telo, I. Transition in Albania : Achievements and challenges. Page 185. MËSONJËTORJA. Tiranë 2005.

The Illyrians and Illyria by the ancient authors. Tiranë 1965. Faqe 133.

Lole. Dh. Përmet and its areas until 1912. LUARASI. Page 14-96. Tiranë 2000.

Mazniku, L. Rural sociology. UBT. Page 84-90. Tiranë 2004.

Misja, V., Vejsiu Y., Bërxholi A., The population of Albania ( Demographic study ), Page 150-163. Tiranë 1987.

Muka, A. The walls of the rural dwelling, Albanian Ethnography, Nr.17, 1990.

Muka. Ali. The rural dwelling and the big family. Page 42-75. 344-351. Publication of the Academy of Sciences. Tiranë 2001.

Selenica. T. Albania in 1927. Page . 89. TIRANA. Tiranë 1928.

Sheme. S. Chameria. The place, population and the economic life. Page 114-117. "PROGRES". Tiranë 2005.

Shkurti. S. Albanian Ethnography Nr. 17. The rural dwellings and the agricultural economy in medieval Albania. Page 4-35. Tiranë 1997. Straboni. Geography. Moscow 1964. Page 295.

Thëngjilli, P., The History of the Albanian people (395-1875), Toena publishing house, Tiranë 2004, page.268.

Tirta, M. Movements of the population and the development of the cities (1945-1985), Albanian Ethnography Nr.15, Tiranë 1986.

Tirta, M., Overview of the population who came in dwellings built after the Liberation in agricultural environments, Albanian Ethnography Nr. 13, page .1, Tiranë 1983.

Tirta. M. Albanian Ethnography 18. Migrations of the Albanians. Page 32-71. 169-171. Science . Tiranë 1999. 
a. lowland villages are densely populated, located mainly on the West, like those found in Delvina valley, Korca, Pogradec and Kolonja with $48 \%$ of rural settlements.

b. hilly villages have a smaller population, located mainly on the Eastern suburbs along the valleys of the rivers Black Drin , Mat, Shkumbin, Seman, Vjosa and Drino with 51\% of rural settlements.

c. mountain villages occupied $7.7 \%$ of rural settlements and lay on the rough terrain in the Albanian Alps, in the peripheral region of the Black Drin, Eastern lowland and valleys in the Southern Highlands Province.

According to the economic activity there are:

a. settlements of agricultural economy

b. settlements of mixed-type economy

According to the form of property there:

a. co-operative settlements

b. residential agricultural enterprises

According to the administrative function there are:

a. United settlements, an administrative unit with a number of localities functioning also as an economic entity

b. specific settlements representing a settlement

According to the method of construction ${ }^{12}$ and the density of residential buildings there are:

a. compact settlements with residential concentrations on the slopes and at the foot of the hills

b. less compact settlements, the periphery of which consists of stray dwellings

c. new socialist type settlements, located in distinct areas and known for their compactness of layout and construction.

Periods of changing socio-economic systems, the process of moving from the centralized economy to the free market economy can hardly offer other solutions to the mechanical movement of the population, except being spontaneous. This kind of movement carried with it a number of negative consequences in rural areas $^{13}$. The dissertation titled "The dynamics of the Rural Area System in Gjirokastër District14 " in Human Geography presented on 19. 11. 2001 , to obtain the Master's degree analyzes in Chapter II the issue : "Populating the ecosystem in rural area." In this chapter are also analyzed rural areas hierarchy and their typology and policies regulating the rural settlements.

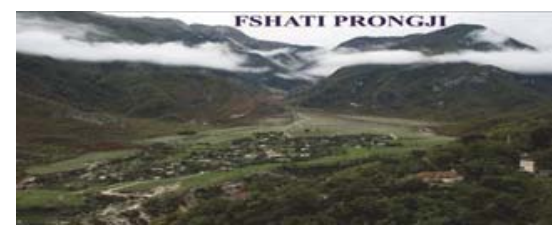

Fig. 4. Prongji village (Gjirokastra district)

This study offers us information of the type :

- Over $98 \%$ of the total number of rural settlements.

- During the historical evolution rural settlements have developed their particular physiognomy and originality. This prcess has affected the social structure, and can be seen as an expression of the organization of agriculture and cultural heritage of its inhabitants, these are reflected on these farming techniques, customs, folklore, traditions, materials, architectural style.

Rural areas are characterized by a landscape architecture with 2-3 storey residential house. These types of settlements have historically affected people's social life, the relationship between them and the outside world.

There are two extreme classical forms, the spread and concentrated, and among them there are other forms which are a mixture of the two types ${ }^{15}$. In Albania, land ownership and social structure have not had a smooth history,due to the

\footnotetext{
12 Bërxholi, A., The changes in the geography of the population in the area Vjosë- Ionian sea (demographic study), Page 57-66. Tiranë 1987.

${ }^{13}$ Hana Lulzim. Telo llia. Transition in Albania: Achievements and challenges. Page 185. MËSONJËTORJA. Tiranë 2005.

14 Sinani.A. The dynamics of the Rural Area System in Gjirokastër district. Page 94-102. Scientific supervior Prof. Dr. Arqile Bërxholi. Gjirokastër November 2011.

${ }^{15}$ Mazniku. Luljeta. Rural Sociology . UBT. Page 84-90. Tiranë 2004.
} 
agricultural raw materials were processed, paper and textiles were also produced, wool processing like carding, weaving, dyeing also took place there.

Present in these settlements were also leather processing and the production of copper and bronze vessels which were sold weekly in the markets of Përmet, Kelcyre and Frashër.

So handicraft items constitute the main economic activity in these places.

This economic system centering on handicrafted items helped establish the necessary economic ties and giving rise to a domestic market that would strengthen the urban-rural relations. Even the author of the book "Çamëria", talks about the general geographical features of 279 villages, settlements of ethnic Albanians whose population was forced to leave their ancestral land in 1944-1945.

These settlements were located in coastal alluvial areas, terraces of river valleys, mountainous areas on the western slopes in soft undulating hills. The most common type is the small rural centers with 50-100 home. After the second half of the XX century we witness a revival of the architectural typology of old traditional houses with two stories.

Socio-economic conditions, the topography of the terrain, construction materials and popular masters have determined apartment's architectural composition. This area is dominated by tower-like houses of great architectural value. The main economic activity was agriculture. At present there Is some evidence, in the form of destroyed homes, mosques, towers, which have been able to remain to this day due to the fact of being isolated in hills or hidden underground therefore not being affected by erosion on the outskirts of the new settlements, which point to a once populous region. These buildings represent important historical monuments in this geographical serving as examples of Venetian and Ottoman influence in this part of Eastern Europe. Especially in the Vjosa valley and its Drino tributary which served as important trade arteries and strategic military points, in the XV century, in the context of the Turkish invasion, the population of many rural settlements was forcibly displaced or left to escape persecution. Destroyed villages in the provinces of Shqeri and Dangëlli, are a proof of villages being destroyed in the middle Ages in the wake of the Turkish invasion. Such settlements by now in ruins are: Lëkurësi, Drenova, Vinjahu Stojani, Devojkari, Vineci, Dardhësi, and Golerani, Toraniku ${ }^{10}$ etc., they exist as toponyms or in the popular memory.

Reasons for abandoning them were conditioned by the social, economic and political factors. In addition to the historical value, these settlements show us the popular form of construction in the time especially before the Turkish invasion. Ruins of Stojan and Dardhës not covered by deposits to the East of the city Permet and to the right of the Vjosa River indicate a large number of houses, which were built in stone using mortar, are clear evidence of an early form of constructing. These rural areas of our country are of special importance concerning the architectural features of the period under study.

One of the main features is their position close to the trade arteries, set deep in the plateau of mountain ridges, a position that clearly reveals their dual character, respectively the agricultural and rural character. Stone buildings, shows clearly that we are talking about a population of a permanent nature preferring to build in durable elements.

These compositional concepts and different architectural elements of construction enjoyed a wide spread popularity among the population in that territory at that time serving as a link between that period and earlier periods, bearing witness to the ethnicity and cultural continuity of our people. The rural dwelling of this period is a simple construction, small and made of stone. So most of the villages of Gjirokastra region, Permet, Kurvelesh etc. are founded as permanent settlements with permanent borders, many centuries before the Turkish invasion. Most of the villages are mentioned for the first time in Turkish documents in 1432.

Traces of this lost history can be found in the diaspora, that were forced to leave these settlements to migrate to southern areas so as to to escape the Turkish yoke.

"Rural Housing and great family11" is a complete work, for whose publication co-operated many architects, historians, archeologists, and geographers and in which are treated issues like: when did the dwellings first started to be build, , the way they were protected, fortification elements and the socio-economic reality of the time. The hilly villages had a relatively balanced development, whereas in the mountainous villages more emphasis was placed on animal husbandry in lowland villages emphasis was placed on agriculture.

According to the type of terrain villages fall into three categories:

\footnotetext{
9 Sheme. Selman. Chameria. The place, population and the economic life. Page 114-117. "PROGRES". Tiranë 2005.

${ }_{10}$ Adhami. Stilian. Overview of the popular culture of the area of Permet. Faqe 22-126. GERVIS. Tiranë 2001.

${ }_{11}$ Muka. Ali. The rural dwelling and the big family. Page 42-75. 344-351. A publication of the Academy of Sciences of Albania. Tiranë 2001.
} 
Përmet, during the second half of XVII century, Përmet had at that time 150 housing units 6 .

Further information concerning the demographic data about the settlement areas is provided by the works of French scholar, Pouqueville, at the beginning of XIX century. Accurate data regarding the number of shops, houses, bridges, religious institutions, farms can be found in Sami Frashëri's work "Kamus-ul Alam p. 1500-1501".

During the years the traditions and the countryside dwellings underwent some changes depending on the economic and social position of the people living in them. The interior of the houses is distinguished by wonderful decorations and inscriptions related to their folk tradition.

A great deal of information is offered also in "Albania in 1927" where we can find accurate information concerning the socio-economic and demographic situation of Albania before World War II. The book serves as a reference for many geographers who have studied rural areas. This work proves the vital importance statistics have played throughout the centuries regarding the development of rural areas.

Under the influence of economic, political, social and administrative factors, rural settlements once again underwent changes regarding their geographical position, they extended or shrank respectively. In the 1431-1432 census Permet province had 121 villages with 3525 houses (21 families/village), and Këlcyra had 41 villages with 1029 houses (25 families/village). The province of Permet included 148 villages in 1840, 1872 had 118 villages, 1923, 105 villages and 104 villages in 1938. In these villages, handicraft items like baskets, saddles, etc were the main forms of economic activity. Starting from 1995, Permet district, as part of Gjirokastra prefecture, consists of 93 villages divided into six municipalities: Center (28 villages), Suke (13), Ballaban (14) Kelcyre (21), Çarçovë ( 9) Frashër (8) ${ }^{8}$.

The establishment of the Ottoman military-feudal regime was associated with the destruction of 15 villages in the provinces of Shqerri and Dangëlli and ruins of some of the abovementioned villages can be seen today. Other elements which prove of the existence of such villages are graves or toponyms like: Lëkurësi, Stojani, Dardhësi, Taraniku, Katundishta, Vinjahu, Teperi etc.. At the end of the XIX century, Gjirokaster region underwent significant socio-economic changes.

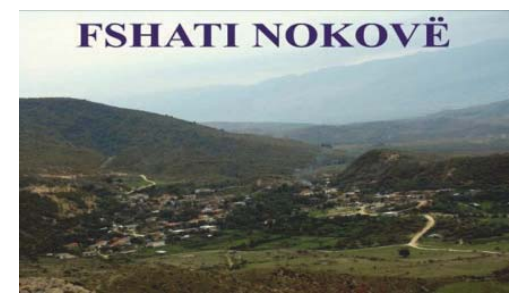

Fig. 3. Nokove village (Gjirokastra district)

From the economic point of view the area was a backward agrarian entity with a distinct rural and agricultural character. The majority of the population Is employed in agriculture and animal husbandry. In the early XIX century Permet experienced a fast-growing period with a population reaching up to 155 villages. An important center was Frasher, the birthplace of the Frasheri brothers, distinguished personalites of Albanian renaissance. Frashër, which is a small mountain town, is named after them. Geographer A.Th. Psalidha from Ioannina, which is a city in in Greece with 116 villages, called Frashër "second city" after the Permet. F. Pouqueville, who was among other things, Napoleon Bonaparte's general consul at the court of Ali Pasha of Ioannina, called Frashër the largest village out of 48 villages included in the then province of Dangëllia. The locals there were involved in agriculture, handicrafts and trade. As regards the societal structure Frasher resembled Albania in miniature. From the religion point of view, here we should mention the foundation of "Tahir Skenderasi" Tekke of Frashër in 1815, whose historical values are recorded in history books. In this tekke in 1880, Abdyl Frashëri called a special gathering of representatives of the Albanian provinces (Vilayet of Monastir and loannina), and there he addressed two important issues: the protection of territorial integrity and the formation of an independent Albanian vilayet.

These settlements besides being centers in which handicraft items were produced, served also as centers in which

\footnotetext{
${ }^{6}$ Adhami. S. Overview of popular culture of the region of Përmet . page 22-126. GERVIS. Tiranë 2001.

7 Selenica. T. Albania in 1927. Page. TIRANA. Tiranë 1928.

${ }^{8}$ Lole. Dh. Përmet and its areas until 1912. LUARASI. Page 14-96. Tiranë 2000.
} 
An important step in the development of rural areas was the gradual shifting to permanent housing as opposed to the temporary settlements. Agriculture and animal husbandry made it possible to create conditions suitable for living. Construction of various settlements using stone spread rapidly within a short period of time.

Stone was present everywhere, easy to find and therefore their spread was massive and quite fast.

Continuous improvement of these settlements was evident in the architectural aspect of the bulidings, in the developmental stages and social organization, in the material culture and traditions associated with the different forms of architecture and functions of these settlements.

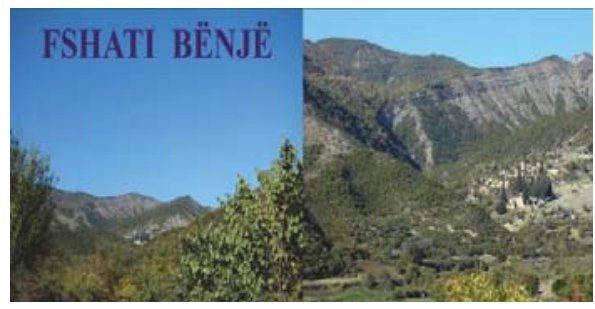

Fig. 2. Village of Bënjë (Përmeti district)

Apart from the aspects that were related to residential buildings, settlements became more diverse in terms of their characteristics regarding their texture.

Various authors have proposed different criteria and classifications closely related to geographic and topographic aspects (mountainous villages, hills and plains) and the territorial-administrative as well as depending on the economic activity that takes place in it. In the work of Mark Tirta ${ }^{3}$ concrete evidence is provided about the internal organization of traditional villages. Evidence pointing to a practice of settlement tradition is much earlier than the fifteenth century. Archeological excavations show signs of villages dating from this century, but also fortifications which show a significant socio-economic development. We have houses built in stones (located on slopes or on rocks, which resemble small fortresses) as farming was the main form of economic activity among the Mediterranean people. In many villages preceding the Ottoman period viticulture, and farming were developed. The inner movements from one place to another, from mountainous to valley areas, brought isolated rural areas closer to urban centers economically, politically, and socially.

Corn growing at this time assumed great proportions something wich goes to show that the population is moving from the mountains to the fields.

Through numerous testimonies we see that the population in these settlements for the most part derives from the mountainous areas during the second half of the XIX century and in the first half of XX century.

Bringing new land under cultivation, led to the development of new realities of socio-economic and ethno-cultural life, which was a powerful factor in the interregional communication, as well as market expansion through the utilization of economic resources, which in turn led to an increase in the rate of production and a better standard of living which was previously something unusual for the population. The withdrawal of the population in the mountains happened because of special reasons of a political nature (the great cruelty of the invaders). Demands for new economic resources made in the late nineteenth and early twentieth century, resulted in the shifting of population from the mountains into the fields, something which paved the way for social transformations and developments. Different villages grew at the junctions of main roads linking different regions of our country. People tended to group themselves near the handicrafting centers, in this way the lot of them who could not cultivate land could make a living in the city. From ancient authors we learn that ".. all Epirus and Illyria are densely populated ${ }^{4 " .}$

This fact regarding the density of population in antiquity is reinforced in Tit Livi's work "The establishment of the city $^{5 "}$. Later the number of settlements grew further, but this growth and the following development, were set off as a result of numerous wars and destructions brought about by various invaders. According to Evlia Çelebiu, who visited

3 Tirta. M. Albanian Ethnography 18. Migrations of the Albanians. Page 32-71. 169-171. Science. Tiranë 1999.

${ }^{4}$ Straboni. Geography. Moscow 1964. Page 295.

5 The Illyrians and Illyria by the ancient authors. Tiranë 1965. Page 133. 


\section{Theory and Methodology}

Typology is varied and reflects the special features of natural, historical, psychological, ethnographic and economic factors.

According to the size criterion we have:

a. small village, up to 500 inhabitants, 69 ones that occupy $72 \%$ of the total area.

b. average village, $500-1000$ inhabitants, 21 ones that occupy $22 \%$ of the total area.

c. large village, over 1000 inhabitants, 6 ones or $6 \%$ of the total area.

According to the method of construction and location there are:

a. compact.

b. with regular structure

c. listed structure

d. spread, with stray houses, but with arrable land

e. linear, in terms of typology of road infrastructure, ease of communication and transport

According to the schematic presentation of the setting there are:

a. linear expansion, as opposed to the road network, river, water

b. circular stretch, around a central square

Just by looking at a given village we can say that their shape is an adaptation to the natural and social conditions.

\section{Results and Discussion}

In the work "The Albanian population" is analyzed the network of residential centers. During the years of socialist construction in the country, as a result of the economic factors the network of rural residential areas expanded in three ways:

1. Through the process the establishment of socialist relations in agriculture, land reclamations, river restoration, the opening of new lands.

2. Through the development of a series of sites located in lowland areas of the country as a new village center

3. Through the establishment of residential centers after earthquakes

Each geographical area, under the influence of a number of social, economic, geographical and historical factors has established its own network of residential centers, with their particular physiognomy, size, layout and construction features.

Of special interest is the analysis of the distribution of settlements according to their elevation, through which it is seen the degree of uniformity of the population within the territory of our country (hilly in percentage). By analyzing the overall development of socio-economic, geographical, urban dynamics, landscape features, administrative organization, we notice a varied typology of settlements.

The size of the settlements and their economy were closely similar to each other. The development of the agricultural economy (three categories: cultivated lands, vineyards and gardens) depend to a large extent on the amount of people able to work, consequently on the size of the dwelling.

Fields account for the majority of land under culture; they were an important indicator which established the character of a settlement. Lands are used for two purposes which show that agriculture and animal husbandry have been the two main economic activities, tied and intertwined with each other. The Ottoman records of the XV-century provide a clear panorama concerning the peasant settlements, there we can find a thorough information about the Albanian Vilayets, carried out in 1431-1432, with an overall average of Albanian Sanjak, consisting of 20.8 houses for each township.

The most populated parts were the hilly areas of South Albania and to a smaller degree the western coastal areas of Albania and hilly villages in their vicinity. Rural areas are the earliest settlements, which have existed throughout the history of the development of Albanian society.

Various authors have identified various features of rural settlements ${ }^{2}$. In ancient times as a result of the concentration of population on mountaintops, animal husbandry was the main economy activity which enabled the survival of the population.

${ }^{2}$ Axhemi. S. Geography of the population and settlements. Page 190-211. ALSA. Tiranë 2007. 


\title{
Features of Rural Settlements: Gjirokastra Region Case
}

\author{
Albina Sinani \\ Associate Professor, "Eqrem Çabej" University, Gjirokastër, Albania, Department of Geography, \\ Faculty of Education and Social Sciences, Gjirokastër, Albania \\ Email: sinalbina@yahoo.com
}

\section{Doi:10.5901/ajis.2016.v5n3s1p269}

\section{Abstract}

Like other scholars of different disciplines, geographers have established their particular feature, through numerous studies. Proper studies, such as studies of the settlements and the degree of use of rural territories, are carried out even in the field of rural geography. The vast majority of settlements as well as most of human potential in the territory of Albania (about 58\%) are located in the rural area. Geographical contributions to the study of rural settlements consist in high levels of information also in their dynamics related to time and space, necessary for decision-making institutions in the service of sustainable rural development. Support specialists in various fields, the role of geography are a priority in the study of rural areas settlements, on the basis of natural knowledge, socio-economic and diverse research methods. During the historical periods, depending on natural, political, socio-economic factors, the demographic and administrative organization of urban and rural areas in Albania have established their physiognomy and authenticity. The number, scope and functions of rural areas settlements have been the subject of study carried out by many authors who have analyzed not only nationally, but also regionally and locally. $A$ particular case is the district of Gjirokastra, where the rural migration has brought about many negative effects. Administrative divisions have a direct impact on the number, size and rational distribution of settlements. During the previous regime, their network was transformed, not only in spatial terms, but also from the functional point of view and typology-wise. After 1989, political, economic and legal changes brought about the need to alter the old forms of governance and the performance of the administrative-territorial reform had a multilateral impact on the network of rural settlements.

Keywords: rural settlements, rural development, material culture, terraces, rural dwellings

\section{Introduction}

Documents with a great deal of information about rural settlements and their economy have been made available recently.

We should say that Ottoman cadastres are of great value regarding their extensive and detailed information because in them it is clearly documented the true nature, size, main economic resources, relations with civic centers, economic power, role of agriculture, crops, in the Albanian medieval village ${ }^{1}$.

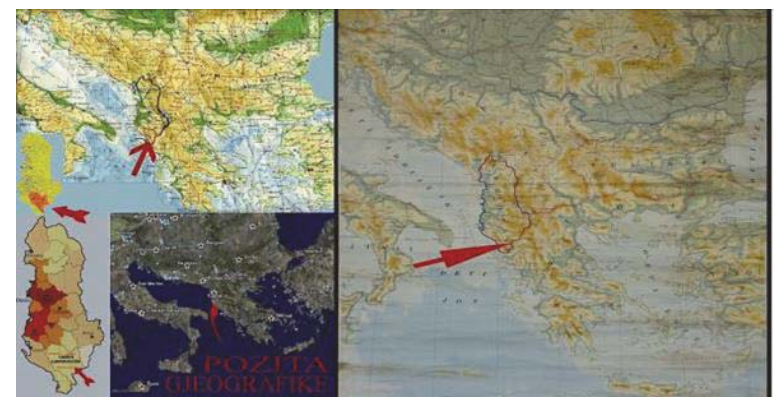

Fig. 1. Geographical position of Gjirokastra region

1 Shkurti. S. Albanian Ethnography Nr. 17. Rural settlements and agricultural economy in medieval Albania. Page 4-35. Tiranë 1997. 


\section{Conclussions and Recommendations}

\subsection{Conclusions}

- Albania's honey was natural, botalically rich with bouyant variety of floral sources, pure and not thermally processed;

- About half (14 out of 30) honey samples were monofloral with a dominance of the Genus of Castanea, Arbutus, Erica, Rosa, Tilia, Artemisia, and of the Ericaceae Family;

- 16 out of 30 honey samples were polyfloral, rich with pollen grains variety; and

- The main pollen grains present in honey samples were those of the Genus of Arbutus, Artemisia, Anchusa, Castanea, Centaurea, Coronilla, Crepis, Erica, Lotus, Melilotus, Ononis, Quercus, Rosa, Rubus, Thymus, Tilia, Trifolium, which serve as the most preferred food for bees.

\subsection{Recommendations}

- To protect the specific characteristics of honey based on the pollen grains dominance on it, it is recommended to the bee farmers to protect natural honey.

- To protect the consumers by false honey, it is recommended that the responsible institutions not only add pollen analysis as part of the standards of honey commercialization, but they also should inspect its usage rigorously.

- Promotion of the honey quality by the institutions and the responsible organizations in the international market would create the possibility of exporting Albanian honey and it would increase the investment in this part of the economy as well.

\section{References}

Avetisjan, B. M. (1950). Uproshennij acetoliznij metod obrabotniki i pilci. Bot. Zhurnal T. 35, N. 4: 385-386.

Erdtman, G. (1956). Morfologija pilci i sistematika rastenij, Angiosperma. Moskva: pp. 12-14, 25-85.

Faegri, K., \& Iversen, J. (1989). Textbook of pollen analysis. Ivedition, London: pp.11-186.

Ferrazi, P., Patetta, A., \& Manino, A. (1990). Caraterizzazione dei mieli della Valle Maira. Apicultura mod. 81: 13-26.

Kapidani, G. (1996). Bazat e palinologjisë. Spore dhe polene të disa bimëve të sotme të Shqipërisë. Monografi: pp. 55-178.

Louveaux, J., Maurizio, A., \& Vorwohl, G. (1978). Methods of melissopalinology. Bee World 59 (4): 139-157.

Moore, P. D., \& Webb, J. A. (1978). An illustrated guide to pollen analysis. Department of Plant Sciences, King's College, London: pp. 47-77.

Pupuleku, B. (2001). Studimi melissopalinologjik i mjaltërave të rajonit Elbasan dhe i poleneve të disa bimëve mjaltore. University of Tirana, Ph. D Thesis, pp. 20-45.

Ricciardelli D'Albore, G. (1998). Mediterranean melissopalynology. Universita degli studi di Perugia, Facolta di Agraria, Istituto di Entomologia agraria: pp. 24-448.

Ricciardelli D'Albore, G., Quaranta, M. (1991). Caratteristiche organolettiche e microscopiche dei mieli della Toscana. Apicolt. mod. 82: 171-178

Smoljaninova Gollupkova, V. F.(1953). L. A. K. Metodike issledovania pilci. Dok. Ak. Nauk. SSSR T.L XXXVIII. N 3: 125-129 
Chart 2. The frequence of monofloral and polyfloral honey in 30 samples studied

Referring to the above charts and tables, the following results were obtained:

- 14 honey samples resulted to be monofloral, respectively to the stations of: Kukës, Bajram Curri, Pukë, Koplik, Burrel, Alarup, Mallakastër, Krrabë, Elbasan, Gramsh, Çermenikë, Lezhë, Priskë and Krujë. Honey samples of the stations: Kukës, Bajram Curri, Pukë, Koplik, Alarup and Çermenikë resulted to be monofloral of the Castanea Genus, while honey of the stations: Mallakastër, Gramsh and Krrabë was monofloral of the Ericaceae Family. Honey sample of the station of Kruje was monofloral of the Erica Genus, while the honey of the station of Elbasan was monofloral of the Artemisia Genius. The Tilia Genus was presented as dominant to the honey samples of the station of Burrel, thus giving it the monofloral characterics, while the honey of the station of Priskë was monofloral with a dominance of pollen grains of Arbutus Genus;

- Honey samples of the stations: Korçë, Prespë, Ersekë, Libofshë, Gjinar, Mat, Starovë, Voskopojë, Tepelenë, Sarandë, Steblevë, Librazhd, Rrajcë, Gjirokastër, Llogara and Divjakë resulted to be polyfloral;

- Honey of the stations: Steblevë, Librazhd, Çermenikë, Ersekë, Korçë, Burrel, Rrajcë, Starovë and Libofshë were the most rich one with various types of pollen grains, respectively with 56, 53, 52, 49, 46, 45, 44 and 43 types of pollen grains.

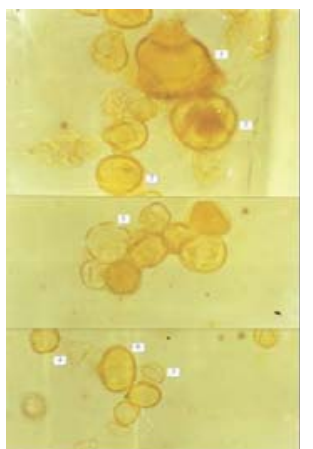

Photo 1: Station Steblevë - Polyfloral honey: 1. Epilobium, 2. Arbutus, 3. Cruciferae, 4. Eucalyptus, 5. Rosmarinus, 6. Trifolium, 7. Prunus.

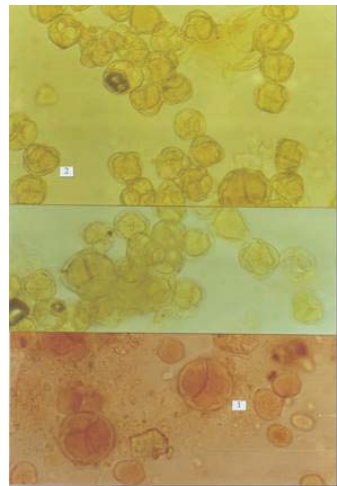

Photo 2: Station Krrabë - Monofloral honey of Ericaceae Family 1. Arbutus, 2. Erica 


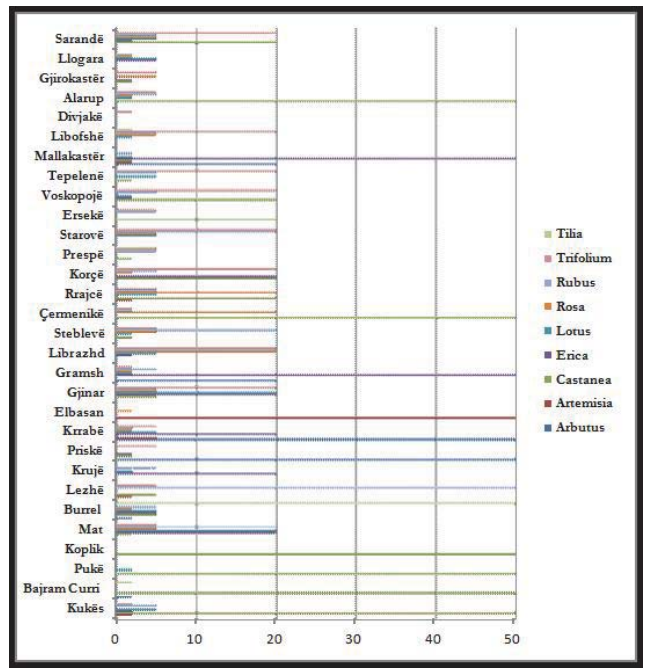

Chart 1. Pollen grains of high frequency found in studied honey samples

Table 2. Geographic location and botanical orygin of studied honey

\begin{tabular}{|l|c|l||}
\hline \hline Location & Types of pollen grains & Botanical origin \\
\hline \hline Kukës & 35 & Monofloral of Castanea Genus \\
\hline Bajram Curri & 34 & Monofloral of Castanea Genus \\
\hline Pukë & 32 & Monofloral of Castanea Genus \\
\hline Koplik & 33 & Monofloral of Castanea Genus \\
\hline Mat & 38 & Polyfloral \\
\hline Burrel & 45 & Monofloral of Tilia Genus \\
\hline Lezhë & 35 & Monofloral of Rubus Genus \\
\hline Krujë & 32 & Monofloral of Erica Genus \\
\hline Priskë & 27 & Monofloral of Arbutus Genus \\
\hline Krrabë & 40 & Monofloral of Ericaceae Family \\
\hline Elbasan & 28 & Monofloral of Artemisia Genus \\
\hline Gjinar & 42 & Polyfloral \\
\hline Gramsh & 40 & Monofloral of Ericaceae Family \\
\hline Librazhd & 53 & Polyfloral \\
\hline Steblevë & 56 & Polyfloral \\
\hline Çermenikë & 52 & Monofloral of Castanea Genus \\
\hline Rrajcë & 45 & Polyfloral \\
\hline Korçë & 46 & Polyfloral \\
\hline Prespë & 44 & Polyfloral \\
\hline Starovë & 43 & Polyfloral \\
\hline Ersekë & 49 & Polyfloral \\
\hline Voskopojë & 42 & Polyfloral \\
\hline Tepelenë & 34 & Polyfloral \\
\hline Mallakastër & 32 & Monofloral of Ericaceae Family \\
\hline Libofshë & 43 & Polyfloral \\
\hline Divjakë & 22 & Polyfloral \\
\hline Alarup & 31 & Monofloral of Castanea Genus \\
\hline Gjirokastër & 25 & Polyfloral \\
\hline Llogara & 45 & Polyfloral \\
\hline Sarandë & 39 & Polyfloral \\
\hline & & \\
\hline
\end{tabular}




\begin{tabular}{|c|c|c|c|c|c|c|c|c|c|c|c|c|c|c|c|c|c|c|c|c|c|c|c|c|c|c|c|c|c|c|c|}
\hline 151. & |Platanus & & & & & & & & & & & & & & & $\begin{array}{ll}\mathrm{r} \\
\end{array}$ & & & & & & & & $\bar{r}$ & & & & & & & $\mathrm{i}$ \\
\hline 152. & Poa & & & & & & & & & & & & & & & & \begin{tabular}{|l|l}
$\mathrm{i}$ & \\
\end{tabular} & & & & & & & & & & & & & & \\
\hline 153. & Polygala & & & & & & & & & & & & & $r$ & & & & & & & & $i$ & & & & & & & & & \\
\hline 154. & Polygonum & $i$ & & & & & & $r$ & & $\mathrm{r}$ & & & & & & \begin{tabular}{|l|}
$r$ \\
\end{tabular} & & & & & & 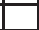 & i & & & & & & & & \\
\hline 155. & Populus & & & & & & & & & & & & & & \begin{tabular}{|l|}
$r$ \\
\end{tabular} & $\mathrm{~s}$ & & & & & & & & & & & & & & & \\
\hline 156. & Potentilla & $r$ & & & & & & & & & & & $\mathrm{~s}$ & & & & \begin{tabular}{|l|}
$\mathrm{i}$ \\
\end{tabular} & & & & & & & & & & & & $\mathrm{r}$ & $r$ & $\mathrm{i}$ \\
\hline 157. & Poterium & & & & & $\begin{aligned} r \\
\end{aligned}$ & & & & & & & & & & & & & & & & & & & & & & & & $r$ & \\
\hline 158. & Primula & & & & & & & & & & & & & $\mathrm{i}$ & & & & & & & & & & & & & & & 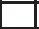 & 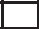 & \\
\hline 159. & Prunus & & $r$ & $r$ & & & $i$ & & $r$ & $r$ & & & $\mathrm{i}$ & $r$ & \begin{tabular}{|l|}
$r$ \\
\end{tabular} & $r$ & \begin{tabular}{|l|}
$\mathrm{i}$ \\
\end{tabular} & $\mathrm{i}$ & & $\mathrm{i}$ & & & $r$ & $i$ & & & & & & & $i$ \\
\hline 160. & Punica & & & & & & & & $r$ & & & & & & & & \begin{tabular}{|l|}
$\mathrm{i}$ \\
\end{tabular} & $\mathrm{i}$ & & & & & & & & & & & & & \\
\hline 161. & Pyrus & & $r$ & & & & & $r$ & & & & & & & & & & & & & & $i$ & & & & & $\mathrm{r}$ & & $r$ & $\mathrm{i}$ & \\
\hline 162. & Quercus & $\mathrm{s}$ & $r$ & & & $\mathrm{~s}$ & $r$ & $r$ & & & & & & $i$ & $\mathrm{~s}$ & \begin{tabular}{|l|}
$r$ \\
\end{tabular} & \begin{tabular}{|l|}
$r$ \\
\end{tabular} & \begin{tabular}{|l|}
$r$ \\
\end{tabular} & $\mathrm{r}$ & $\mathrm{i}$ & & $r$ & \begin{tabular}{|l|}
$r$ \\
\end{tabular} & - & & 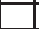 & & \begin{tabular}{|l|}
$r$ \\
\end{tabular} & $\mathrm{i}$ & $\mathrm{s}$ & \\
\hline 163. & Ranunculus & & $r$ & & $r$ & & & $r$ & & & & & & $i$ & & i & \begin{tabular}{|l|}
$\mathrm{i}$ \\
\end{tabular} & & i & - & & 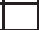 & 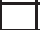 & $\mathrm{i}$ & & \begin{tabular}{|l|}
$\mathrm{i}$ \\
\end{tabular} & & 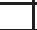 & \begin{tabular}{|l|}
$r$ \\
\end{tabular} & $\mathrm{i}$ & \\
\hline 164. & Raphanus & & & & & & & & & & & & & & \begin{tabular}{|l|}
$\mathrm{i}$ \\
\end{tabular} & & & & & & & $i$ & & & & & & & 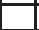 & & \\
\hline 165. & Rapistrum & & & & & & & & & & & & & & & & $i$ & & i & i & & & & & & i & & & & & \\
\hline 166. & Rhamnus & & $r$ & $r$ & $r$ & i & $r$ & & & & $\mathrm{i}$ & & & 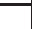 & & $\mathrm{s}$ & \begin{tabular}{|l|}
$\mathrm{i}$ \\
\end{tabular} & & 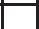 & & & 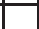 & \begin{tabular}{|l|}
$\mathrm{i}$ \\
\end{tabular} & $r$ & & 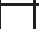 & \begin{tabular}{|l|}
$r$ \\
\end{tabular} & \begin{tabular}{|l|}
$r$ \\
\end{tabular} & $\mathrm{r}$ & & $\mathrm{i}$ \\
\hline 167. & Rhus & & & & $r$ & & $i$ & & & $r$ & & & & & . & & 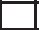 & & & & & 4 & 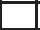 & - & & 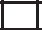 & & - & 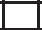 & $\mathrm{r}$ & \\
\hline 168. & Robinia & & & & $r$ & & & & & & & & & $i$ & \begin{tabular}{|l|}
$\mathrm{i}$ \\
\end{tabular} & $\mathrm{s}$ & $\mathrm{i}$ & & $\mathrm{S}$ & & & 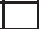 & 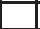 & 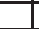 & $r$ & & & 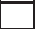 & $r$ & 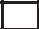 & \\
\hline 169. & Rosa & & & & & s & $r$ & & & & $r$ & $r$ & \begin{tabular}{|l|}
$\mathrm{s}$ \\
\end{tabular} & $r$ & $\mathrm{~s}$ & \begin{tabular}{|l|}
$\mathrm{s}$ \\
\end{tabular} & \begin{tabular}{|l|}
$\mathrm{S}$ \\
\end{tabular} & \begin{tabular}{|l|}
$\mathrm{S}$ \\
\end{tabular} & $r$ & & $\mathrm{~s}$ & $\mathrm{i}$ & & & & s & & $\mathrm{r}$ & s & $r$ & $\mathrm{~s}$ \\
\hline 170. & Rosmarinus & & & & & & & & & & & & & $r$ & & $\mathrm{~s}$ & & & & & & & & & & & & & & & \\
\hline 171. & Rubus & $\mathrm{s}$ & $i$ & $i$ & $\mathrm{i}$ & $\mathrm{S}$ & $s$ & $\mathrm{D}$ & $\mathrm{s}$ & $\begin{array}{ll}\mathrm{i} \\
\end{array}$ & $\mathrm{r}$ & $\mathrm{i}$ & \begin{tabular}{|l|}
$s$ \\
\end{tabular} & $s$ & $\mathrm{~S}$ & $\mathrm{~S}$ & \begin{tabular}{|l|}
$r$ \\
\end{tabular} & $\mathrm{~s}$ & $\mathrm{~s}$ & $\mathrm{~s}$ & $\mathrm{~S}$ & $\mathrm{~s}$ & $\mathrm{~s}$ & $\mathrm{~s}$ & $\mathrm{r}$ & $\mathrm{s}$ & \begin{tabular}{l|}
$\mathrm{i}$ \\
\end{tabular} & $\mathrm{s}$ & $i$ & $r$ & $\mathrm{~s}$ \\
\hline 172. & Rubiaceae & & & & & & & & & & & i & & & & & & & & & & & & & & & & & 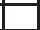 & & \\
\hline 173. & Rumex & & $r$ & $r$ & $r$ & & $i$ & & & & & & & & & & & 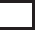 & & & & $i$ & & & & 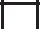 & & 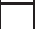 & 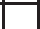 & 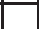 & $i$ \\
\hline 174. & Rutaceae & & & & & & & & & & & i & & & & & & & & & & & & & & & & & & & \\
\hline 175. & Salix & & $r$ & $r$ & $\mathrm{~s}$ & $r$ & 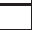 & & & $r$ & 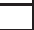 & 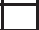 & & & 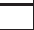 & & & 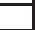 & 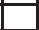 & & & 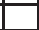 & \begin{tabular}{|l|}
$\mathrm{i}$ \\
\end{tabular} & & & i & & $\mathrm{s}$ & $\mathrm{s}$ & & \\
\hline 176. & Salvia & & & & $r$ & $i$ & & $i$ & & & & & & & & & & & - & & & $i$ & & & & $\mathrm{i}$ & $r$ & & & $\mathrm{~s}$ & \\
\hline 177. & Sambucus & & & $\mathrm{r}$ & $r$ & $i$ & $i$ & & & & $\mathrm{i}$ & $r$ & $\mathrm{i}$ & & 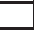 & & 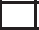 & 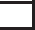 & $r$ & $i$ & & - & $r$ & $r$ & & 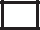 & & $\begin{array}{ll}r \\
\end{array}$ & 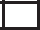 & $\mathrm{r}$ & $r$ \\
\hline 178. & Sanguisorba & $r$ & & & $r$ & & $i$ & 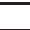 & & & & & & & & & 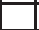 & 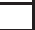 & & & \begin{tabular}{|l|}
$\mathrm{i}$ \\
\end{tabular} & 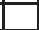 & & 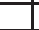 & & & & & $r$ & $r$ & $r$ \\
\hline 179. & Saponaria & & & & & $i$ & & & & & & & & & \begin{tabular}{|l|}
$r$ \\
\end{tabular} & & & $\begin{array}{ll}r \\
\end{array}$ & & $\mathrm{i}$ & & 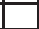 & & $\mathrm{i}$ & & & & & 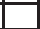 & 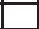 & $r$ \\
\hline 180. & Satureja & $r$ & & & & & & & & & & & & & \begin{tabular}{|l|}
$\mathrm{i}$ \\
\end{tabular} & & $\mathrm{i}$ & & - & & & 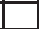 & & 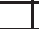 & & & & & 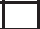 & 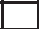 & \\
\hline 181. & Saxifraga & & $r$ & & & & & $r$ & & $r$ & & & & & & & 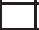 & & i & & & - & & - & & & & & 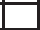 & 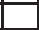 & \\
\hline 182. & Scrophularia & & $r$ & & & & & $i$ & & $r$ & & $r$ & $\mathrm{i}$ & & 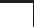 & & & & & $i$ & & $i$ & & 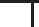 & & & & & 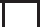 & $i$ & \\
\hline 183. & Sedum & & & $r$ & $\mathrm{r}$ & $i$ & & $r$ & & & & & \begin{tabular}{|l|}
$\mathrm{i}$ \\
\end{tabular} & & & & & & & & & & & & & & & & $r$ & $r$ & \\
\hline 184. & Senecio & & & $i$ & $i$ & & & $r$ & $\mathrm{r}$ & & $\mathrm{r}$ & 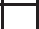 & $i$ & & 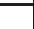 & i & 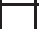 & 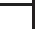 & 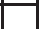 & $\mathrm{s}$ & & 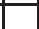 & 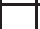 & $\mathrm{i}$ & & 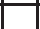 & \begin{tabular}{|l|}
$r$ \\
\end{tabular} & 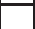 & 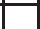 & $r$ & \\
\hline 185. & Sideritis & & & & & & & & & & & & & & & & & & & & & & & & & & & \begin{tabular}{|l|}
$\mathrm{i}$ \\
\end{tabular} & & $r$ & \\
\hline 186. & Silene & & & & & & & $r$ & & & & $r$ & & & & & & & & & & & & 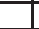 & & & & . & & & \\
\hline 187. & Silybum & & & & & & & & & & & & & & \begin{tabular}{|l|}
$\mathrm{i}$ \\
\end{tabular} & & & & & & & & & & & & & & & & \\
\hline 188. & Sinapis & & & & & $r$ & & & $\mathrm{~s}$ & & & & & & \begin{tabular}{|l|}
$\mathrm{i}$ \\
\end{tabular} & & & & & & & & & & & $\mathrm{i}$ & & $\begin{array}{ll}r \\
\end{array}$ & & & \\
\hline 189. & Smilax & & $r$ & & & & & & & & & & & & & & & & & & \begin{tabular}{|l|}
$\mathrm{i}$ \\
\end{tabular} & & & & & 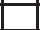 & & 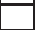 & & & \\
\hline 190. & Solidago & & & & & & & & & & $\mathrm{i}$ & $\mathrm{i}$ & & & & & \begin{tabular}{|l|}
$\mathrm{i}$ \\
\end{tabular} & & & & & & i & & & & & & & & \\
\hline 191. & Spartium & & & & & & & & & & & & & & & & & & & & \begin{tabular}{|l|}
$r$ \\
\end{tabular} & & & & & & & & & & \\
\hline 192. & Stellaria & & & & & & & & & & & & \begin{tabular}{|l|}
$\mathrm{i}$ \\
\end{tabular} & & & & & & $\begin{aligned} r \\
\end{aligned}$ & & & $i$ & \begin{tabular}{|l|}
$r$ \\
\end{tabular} & & & & & & & & \\
\hline 193. & Symphytum & & & & & & & & & & & & & & & & & & & & & 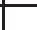 & & & \begin{tabular}{|l|}
$\mathrm{i}$ \\
\end{tabular} & & & & & & \\
\hline 194. & Thalictrum & & & $r$ & & & & & & & & & & & & $\mathrm{i}$ & & & & & & & & & & & & & & & \\
\hline 195. & Tamarix & & & & & & & & & & & & & & \begin{tabular}{|l|}
$r$ \\
\end{tabular} & & & & & & & 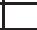 & & & & & & & & & \\
\hline 196. & Taraxacum & & & & & & & & $r$ & & & & & & & & & & & & & & & & & & & & & & \\
\hline \begin{tabular}{|l|}
197. \\
\end{tabular} & Teucrium & & & & & & & & & & & & & & & & & & & $\mathrm{i}$ & & & & & & & & & & & \\
\hline 198. & Thesium & & & & & & & & & & & & & & & & & $r$ & & $\mathrm{~s}$ & & $i$ & & $\mathrm{~s}$ & & 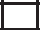 & & & 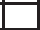 & 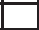 & \\
\hline 199. & Thymus & $r$ & $\mathrm{r}$ & $r$ & $r$ & $r$ & $\mathrm{~s}$ & $i$ & \begin{tabular}{|l|}
$r$ \\
\end{tabular} & & $\mathrm{~s}$ & & \begin{tabular}{|l|}
$\mathrm{s}$ \\
\end{tabular} & $\mathrm{r}$ & $\mathrm{s}$ & & \begin{tabular}{|l|}
$r$ \\
\end{tabular} & $\mathrm{~s}$ & $\mathrm{~s}$ & i & $\mathrm{s}$ & $\mathrm{s}$ & $\mathrm{s}$ & & & $\begin{array}{ll}r \\
\end{array}$ & \begin{tabular}{|l|l}
$\mathrm{s}$ \\
\end{tabular} & $\begin{aligned} r \\
\end{aligned}$ & $\mathrm{~s}$ & $\mathrm{~s}$ & $r$ \\
\hline 200. & Tilia & & $r$ & & & & D & & & & & & \begin{tabular}{|l|}
$\mathrm{i}$ \\
\end{tabular} & & \begin{tabular}{|l|}
$\mathrm{i}$ \\
\end{tabular} & & & & & $\mathrm{s}$ & & & & & & $\mathrm{r}$ & & 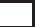 & 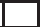 & & \\
\hline 201. & Tordylium & $i$ & & & & & $r$ & & $r$ & & & & & & \begin{tabular}{|l|}
$\mathrm{i}$ \\
\end{tabular} & & & & & & \begin{tabular}{|l|}
$r$ \\
\end{tabular} & & & & & & & & & & $\mathrm{~s}$ \\
\hline 202. & Trifolium & $r$ & & & & $\mathrm{~s}$ & & $\mathrm{~s}$ & & \begin{tabular}{|l|l}
$\mathrm{s}$ \\
\end{tabular} & $\mathrm{s}$ & $\mathrm{i}$ & \begin{tabular}{|l|}
$\mathrm{S}$ \\
\end{tabular} & $r$ & \begin{tabular}{|l|}
$\mathrm{S}$ \\
\end{tabular} & $\mathrm{s}$ & $\begin{aligned} r \\
\end{aligned}$ & $\mathrm{~s}$ & $\mathrm{~S}$ & $\mathrm{~s}$ & $\mathrm{~S}$ & $\mathrm{~s}$ & \begin{tabular}{|l|}
$\mathrm{S}$ \\
\end{tabular} & \begin{tabular}{l|l} 
\\
\end{tabular} & $\mathrm{i}$ & $\mathrm{S}$ & \begin{tabular}{|l|}
$r$ \\
\end{tabular} & $\mathrm{~s}$ & $\mathrm{~s}$ & & $\mathrm{~s}$ \\
\hline 203. & Tribulus & & & & & & & & & & & & & & & & & & & & & & & & & & $r$ & & & & \\
\hline 204. & Trigonella & & & & & & $i$ & & & & & & & & & $\mathrm{i}$ & & & & & & 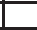 & & & & & & & & & \\
\hline 205. & Tussilago & $r$ & & & & & $i$ & & & & & $r$ & & & & $i^{2}$ & \begin{tabular}{|l|}
$\mathrm{i}$ \\
\end{tabular} & & & & \begin{tabular}{|l|}
$r$ \\
\end{tabular} & & \begin{tabular}{|l|}
$r$ \\
\end{tabular} & & & & & & & & \\
\hline 206. & Typha & & & & & & & & & & & & & & & & & & & & & & & & & & & & & & $r$ \\
\hline 207. & Ulmus & & & & & $r$ & & & & & i & & $\mathrm{i}$ & & & & 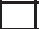 & 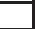 & $\mathrm{r}$ & & & $i$ & & & & i & & & & & \\
\hline 208. & Umbelliferae & & & & & & & & & & $\mathrm{s}$ & & \begin{tabular}{|l|}
$\mathrm{i}$ \\
\end{tabular} & $r$ & \begin{tabular}{|l|}
$r$ \\
\end{tabular} & & & $\mathrm{i}$ & & & $\begin{array}{ll}r \\
\end{array}$ & & & & & & & & 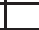 & & \\
\hline 209. & Urtica & $r$ & & & & & i & & $\begin{array}{ll}r \\
\end{array}$ & & & & & $r$ & \begin{tabular}{|l|}
$\mathrm{i}$ \\
\end{tabular} & i & & & $r$ & & $\begin{aligned} r \\
\end{aligned}$ & $i$ & & $\mathrm{i}$ & & & & i & $r$ & & \\
\hline .210. & Verbascum & & & & & & & & & & & & & & \begin{tabular}{|l|}
$\mathrm{i}$ \\
\end{tabular} & & $i$ & & & i & & & & $\mathrm{i}$ & & & & & & & \\
\hline 211. & Verbena & & & & & & & & & & i & & & & & & & & & & & & & & & & & & & & \\
\hline 212. & Veronica & & & & & & $i$ & & & & & & & & & & & & & & & & & & & & & & & & \\
\hline 213. & Vicia & & & & & & & $r$ & & & $\mathrm{~s}$ & & $\mathrm{i}$ & $r$ & \begin{tabular}{|l|}
$r$ \\
\end{tabular} & $r$ & $r$ & $\begin{array}{ll}\mathrm{i} \\
\end{array}$ & & & \begin{tabular}{|l|}
$r$ \\
\end{tabular} & $i$ & & & & & $\begin{array}{ll}r \\
\end{array}$ & $r$ & & & $r$ \\
\hline 214. & Viola & & & & & & $i$ & & & & & & & & & & & & $\mathrm{i}$ & & 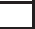 & & & & & & & & & & \\
\hline 215. & Zea & & $r$ & & $\mathrm{i}$ & & & & i & i & & $\mathrm{s}$ & & & \begin{tabular}{|l|}
$r$ \\
\end{tabular} & & 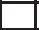 & 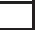 & & & \begin{tabular}{|l|}
$\mathrm{i}$ \\
\end{tabular} & & & & & & \begin{tabular}{|l|}
$\mathrm{S}$ \\
\end{tabular} & & $r$ & & \\
\hline 216. & Xanthium & & $r$ & & 1 & & & & & $\mathrm{i}$ & & & & & & & & 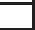 & i & & \begin{tabular}{|l|}
$\mathrm{i}$ \\
\end{tabular} & & 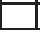 & & & & & & - & & \\
\hline 217. & Fungal sporang & r & $r$ & $r$ & $r$ & $\mathrm{i}$ & $\mathrm{i}$ & $i$ & & $\mathrm{i}$ & & & $r$ & & \begin{tabular}{|l|}
$\mathrm{i}$ \\
\end{tabular} & & $r$ & $r$ & & & & & $r$ & & & & & $r$ & $r$ & $r$ & \\
\hline
\end{tabular}




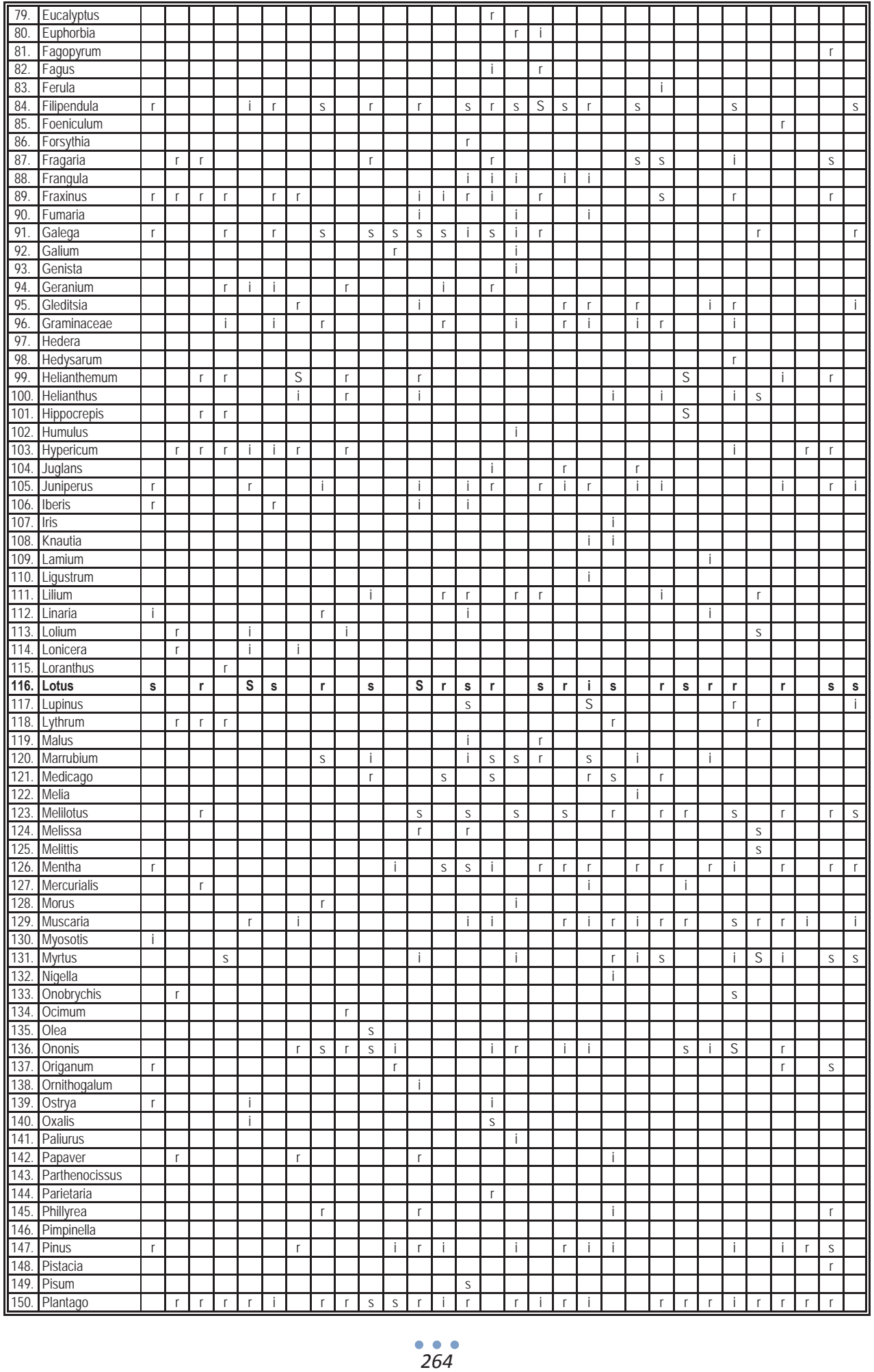




\begin{tabular}{|c|c|c|c|c|c|c|c|c|c|c|c|c|c|c|c|c|c|c|c|c|c|c|c|c|c|c|}
\hline 7. & 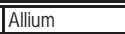 & & & 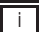 & & $\overline{c r}$ & $\overline{\mathrm{pr}}$ & & & $\bar{i}$ & 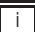 & 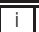 & 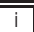 & 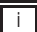 & 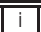 & $\overline{\bar{i}}$ & \begin{tabular}{l|l}
$\mathrm{i}$ \\
\end{tabular} & ss & $\bar{~} \bar{r}$ & & |s & \begin{tabular}{|l|}
$r$ \\
\end{tabular} & $\mathrm{r}$ & \begin{tabular}{l|l}
$\mathrm{i}$ \\
\end{tabular} & & \\
\hline 8. & Alyssun & & & & & & & $r$ & & $r$ & & & & & & & & & & & & & & & & \\
\hline 9. & Alnus & & & & & & & & & & & & & & & & & & & \begin{tabular}{|l|}
$r$ \\
\end{tabular} & s & $\mathrm{r}$ & 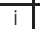 & $\mathrm{r}$ & & \\
\hline 10. & Alyssum & & & & & & & & $\begin{array}{ll}r \\
\end{array}$ & & & & & & & & $i$ & 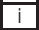 & & & 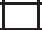 & 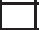 & 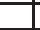 & 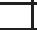 & & \\
\hline 11. & Ambrosia & & & & & & & & & & & & & & & & & & & & & & & & & $r$ \\
\hline 12. & Amni & $r$ & & & & & & & & & & & & & & & & & & \begin{tabular}{|l|}
$\mathrm{S}$ \\
\end{tabular} & $r$ & $\mathrm{r}$ & & & & \\
\hline 13. & Anarrhinum & & & & & & & & & & & & & & & & & & $r$ & & 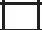 & \begin{tabular}{|l|}
$\mathrm{i}$ \\
\end{tabular} & $r$ & 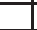 & & $i$ \\
\hline 14. & Anchusa & & & & & & & & & & & & & & & & $i$ & & 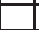 & & & 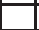 & 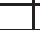 & . & & 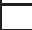 \\
\hline 15. & Anthemis & & & & & $i$ & $r$ & & $r$ & & $r$ & & & i & & & & & & & & $r$ & & & $\begin{array}{ll}r \\
\end{array}$ & $\mathrm{i}$ \\
\hline 16. & Arbutus & & $r$ & & & & $r$ & & & D & $\mathrm{D}$ & & & $\mathrm{S}$ & & & & & & & & & & $\mathrm{i}$ & $\mathrm{s}$ & \\
\hline 17. & Arctium & & $\mathrm{i}$ & & $\mathrm{i}$ & & & i & & & & & & & & & & $\begin{aligned} r \\
\end{aligned}$ & & & & & & & & \\
\hline 18. & Armeria & & & & & & & & & & & & & 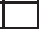 & $\mathrm{i}$ & & 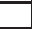 & 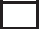 & & & 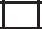 & 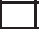 & & 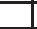 & - & - \\
\hline 19. & Artemisia & $r$ & & & $\mathrm{i}$ & & $i$ & & $\mathrm{r}$ & & $\mathrm{s}$ & D & & $i$ & & & 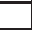 & $r$ & & & 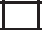 & 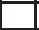 & & 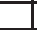 & $r$ & \\
\hline 20. & Asparagus & & & $\mathrm{i}$ & & & $\mathrm{i}$ & \begin{tabular}{|l|}
$i$ \\
\end{tabular} & & & & & & & & & & & & & & & $\mathrm{r}$ & & & \\
\hline 21. & Aster & & & $\mathrm{r}$ & & $i$ & $i$ & \begin{tabular}{|l|}
$i$ \\
\end{tabular} & & & & & & & & & & & & & & & & & & \\
\hline 22. & Astragalus & & & $r$ & & & $r$ & & & & & & & & & & & i & & & 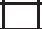 & $\mathrm{s}$ & & & 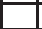 & $r$ \\
\hline 23. & Avena & & & & & & & & & & & & & & $\mathrm{i}$ & & & & & & - & 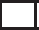 & & & & \\
\hline 24. & Bellis & $r$ & & & & & & & \begin{tabular}{|l|}
$r$ \\
\end{tabular} & & & & \begin{tabular}{|l|}
$\mathrm{i}$ \\
\end{tabular} & & 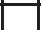 & & 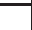 & & & & $\mathrm{i}$ & & & & $r$ & \\
\hline 25. & Betula & & & & & & & & & & & & & & & & & & & & $i$ & & & & & \\
\hline 26. & Bidens & & & & & & & & & & $r$ & & & & $i$ & & & & & & & & & 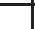 & & \\
\hline 27. & Brassica & $i$ & & $r$ & $r$ & & & & & & & & & & & & & & & & & & & $r$ & & \\
\hline 28. & Bupleurum & & & & & & & & & & & & & & & & $i$ & & \begin{tabular}{|l}
$\mathrm{i}$ \\
\end{tabular} & & & 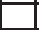 & & 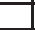 & 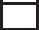 & \\
\hline 29. & Buxus & & & & & & & & & & & & & $\mathrm{s}$ & & & & & 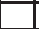 & & & & & 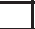 & 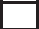 & \\
\hline 30. & Caltha & & & & & & & & & & & & & & & & & $\mathrm{i}$ & & & & & & & & \\
\hline 31. & Campanula & & & $r$ & & & & & \begin{tabular}{|l|}
$r$ \\
\end{tabular} & & $r$ & & & & & & 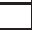 & $\mathrm{i}$ & & 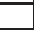 & & & & - & 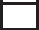 & \\
\hline 32. & Capsella & & & & & & & & & & & & & & & & & & \begin{tabular}{|l}
$\mathrm{i}$ \\
\end{tabular} & $\begin{aligned} r \\
\end{aligned}$ & & $\mathrm{i}$ & & $\mathrm{i}$ & i & $\mathrm{s}$ \\
\hline 33. & Castanea & $D$ & $\mathrm{D}$ & $\mathrm{D}$ & $\mathrm{D}$ & $r$ & $\mathrm{~s}$ & $\mathrm{~s}$ & . & $r$ & $i$ & & $\mathrm{~s}$ & . & & $r$ & $D$ & $\mathrm{~s}$ & $\mathrm{~s}$ & $r$ & & \begin{tabular}{|c|} 
\\
\end{tabular} & $\mathrm{s}$ & $r$ & $r$ & 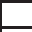 \\
\hline 34. & Carduus & $\mathrm{i}$ & & & & & & & $\begin{aligned} r \\
\end{aligned}$ & & $i$ & & & & & & & & & & & & $r$ & & i & $i$ \\
\hline 35. & Carex & & & & & & & & & & & & & & & i & & & 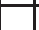 & 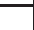 & & 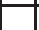 & 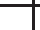 & . & 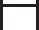 & 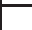 \\
\hline 36. & Carlina & & & & & & & & & & & & & & & & & & & & & 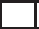 & & . & $r$ & \\
\hline 37. & Carpinus & & & & & & & & & & & & . & & & & - & & - & \begin{tabular}{|c|}
$\mathrm{i}$ \\
\end{tabular} & & . & & 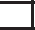 & $r$ & \\
\hline 38. & Carthamus & & & & & & & & & & & & \begin{tabular}{|l|}
$\mathrm{i}$ \\
\end{tabular} & & & & & & & & & & 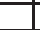 & & & \\
\hline 39. & Centaurea & & & & & & & & $\mathrm{s}$ & & & & \begin{tabular}{|l|}
$r$ \\
\end{tabular} & & & & 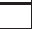 & & $\mathrm{s}$ & \begin{tabular}{|l|}
$s$ \\
\end{tabular} & 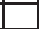 & $\mathrm{s}$ & $\mathrm{S}$ & & $i$ & \\
\hline 40. & Ceratonia & & & $r$ & & & & & & & & & & & & & 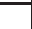 & & & 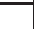 & & & 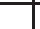 & & 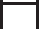 & \\
\hline 41. & Cercis & & & & & & & & & & & & & & & & & $i$ & & & & & & & 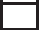 & 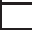 \\
\hline 42. & Cerinthe & & & & & & & & & & & & & & & & $i$ & & & 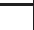 & 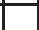 & \begin{tabular}{|l|}
$\mathrm{i}$ \\
\end{tabular} & $\mathrm{i}$ & & & \\
\hline 43. & Ceriastum & & & & & & & & & & & & & & & $i$ & $i$ & & & . & & & & & 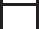 & \\
\hline 44. & Chamomilla & & & & & & & & & & $r$ & & & & & 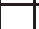 & $i$ & $r$ & & $\begin{aligned} r \\
\end{aligned}$ & & 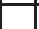 & 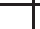 & . & 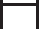 & 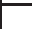 \\
\hline 45. & Chenopodium & & $r$ & & & & & & & & $i$ & $\mathrm{~s}$ & & $\mathrm{~s}$ & $\mathrm{i}$ & & $i$ & & 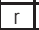 & & $r$ & $\mathrm{i}$ & & 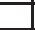 & $\mathrm{s}$ & $\mathrm{s}$ \\
\hline 46. & Chicorium & & & & & $r$ & $i$ & & $\mathrm{~s}$ & 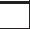 & $\mathrm{i}$ & & & & $r$ & $r$ & $r$ & $r$ & & $\begin{array}{ll}r \\
\end{array}$ & $\mathrm{i}$ & 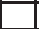 & $\mathrm{i}$ & 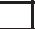 & $r$ & $r$ \\
\hline 47. & Cirsium & & & & & & & & & & & $\mathrm{r}$ & & & $i$ & & & i & $\mathrm{r}$ & & - & 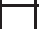 & & 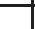 & i & i \\
\hline 48. & Cistus & $i$ & & & & & & & & & & & & & & $\mathrm{i}$ & & 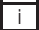 & $r$ & & $\mathrm{i}$ & - & & - & 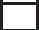 & 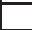 \\
\hline 49. & Clematis & & & $r$ & $r$ & & $\mathrm{i}$ & & $r$ & $r$ & & & \begin{tabular}{|l|}
$\mathrm{i}$ \\
\end{tabular} & & $r$ & & 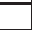 & 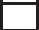 & L & 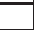 & $i$ & $\mathrm{i}$ & & $\mathrm{i}$ & 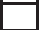 & 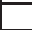 \\
\hline 50. & Convallaria & & & & & & & & & & & & & & & & & & & & & & & $\mathrm{i}$ & & \\
\hline 51. & Colchicum & & & & & & & & & & & & & & & & & & - & & 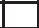 & 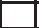 & & & $\mathrm{i}$ & - \\
\hline 52. & Colutea & $\mathrm{s}$ & & & & & & & & & & & & & & & & & & & $i$ & & & & $\begin{aligned} r \\
\end{aligned}$ & \\
\hline 53. & Coronilla & & $r$ & & $r$ & & & $r$ & & & & & & & & & 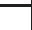 & $\mathrm{i}$ & i & 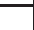 & 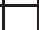 & s & 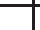 & $\mathrm{s}$ & 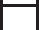 & $\mathrm{s}$ \\
\hline 54. & Corylus & $r$ & $r$ & & & $r$ & $\mathrm{i}$ & & & $r$ & & & & & & $\mathrm{~s}$ & 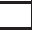 & 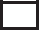 & $r$ & 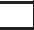 & 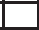 & $\mathrm{i}$ & $\mathrm{s}$ & . & $r$ & 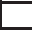 \\
\hline 55. & Crataegus & & & $r$ & & $r$ & & & & $r$ & $\mathrm{~s}$ & & & & & $r$ & 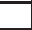 & $i$ & 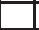 & \begin{tabular}{|l|}
$r$ \\
\end{tabular} & i & i & & 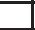 & 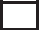 & 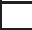 \\
\hline 56. & Cornus & & & & & $i$ & & & & & & & & & & & & & & & & & & & & $r$ \\
\hline 57. & Convolvulus & & & & & $i$ & i & i & & $r$ & & & & & & & & & & & & . & & & & \\
\hline 58. & Crepis & $\mathrm{i}$ & & & & $i$ & $\mathrm{r}$ & & & & $r$ & $\begin{array}{ll}r \\
\end{array}$ & & & $\mathrm{~s}$ & & $i$ & $\mathrm{i}$ & & 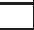 & $r$ & \begin{tabular}{|l|}
$\mathrm{i}$ \\
\end{tabular} & $\mathrm{r}$ & . & 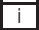 & 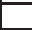 \\
\hline 59. & Cruciferae & & $r$ & & & & & & & & & $\mathrm{r}$ & & $r$ & & $\mathrm{r}$ & $i$ & $\mathrm{i}$ & & & & & & 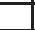 & & 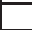 \\
\hline 60. & Cucumis & & & & & & & $r$ & & & & & & & $\mathrm{i}$ & & & & $\mathrm{r}$ & & $\mathrm{i}$ & & & 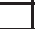 & & $\mathrm{i}$ \\
\hline 61. & Cucurbita & & & & & & & & & & & & & & & & & & & & & & & $\mathrm{i}$ & & \\
\hline 62. & Cupressus & & & $\begin{array}{ll}r \\
\end{array}$ & $r$ & & & & & & & & & i & & $r$ & & & 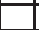 & & & & & & & $i$ \\
\hline 63. & Cydonia & & & & & & & & & & & & & & & $r$ & & & & & & & & & & \\
\hline 64. & Cynoglossum & & & & & & & & & & & & & & & & & & $\mathrm{i}$ & & & & & & & \\
\hline 65. & Cytisus & & & & & & & & & & & & & & $i$ & & & & & & & & & & & \\
\hline 66. & Cyperaceae & & & & & & $\mathrm{i}$ & & & & & & & & & & & & & & & & & & & \\
\hline 67. & Dactylis & & $\mathrm{i}$ & & & & & & & & & & & & & & & & \begin{tabular}{|l}
$\mathrm{i}$ \\
\end{tabular} & & & 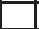 & & & - & - \\
\hline 68. & Daucus & & & $r$ & & & & & & $r$ & & & & & & & & & & & & \begin{tabular}{|l|}
$r$ \\
\end{tabular} & $\mathrm{r}$ & & $r$ & $\mathrm{~s}$ \\
\hline 69. & Delphinium & $\mathrm{r}$ & & & & & & & & & & & & & & & & $\mathrm{i}$ & & & & & & & & \\
\hline 70. & Dipsacus & & & & & $i$ & & & & & & & & & & & & & & & & & & & & \\
\hline 71. & Dittrichia & i & & & & & $\mathrm{i}$ & & & & & & & & $i$ & & $i$ & & & & & & & & & \\
\hline 72. & Dorycnium & & & & & & & & & & & & & & & $\mathrm{i}$ & & & & & & & & & & \\
\hline 73. & Echium & & & & $r$ & & & & & & $i$ & & $\mathrm{~s}$ & & $r$ & & & $r$ & $r$ & $r$ & & 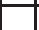 & $r$ & & & \\
\hline 74. & Ecbalium & & & & & & & & r & & & & & & & & & & & & & i & & & & \\
\hline 75. & Eleagnus & & & & & & & & & & & & & & & & & & $r$ & & & & & & & \\
\hline 76. & Epilobium & & & & & $r$ & & & & & & & $\begin{array}{ll}r \\
\end{array}$ & & & $\mathrm{~s}$ & & & & 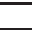 & & 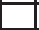 & & & & \\
\hline 77. & Erica & $r$ & & & & $S$ & $\mathrm{~s}$ & & S & $r$ & $\mathrm{~S}$ & \begin{tabular}{|l|}
$\mathrm{i}$ \\
\end{tabular} & \begin{tabular}{|l|}
$S$ \\
\end{tabular} & D & $r$ & & & $\mathrm{~S}$ & & & & & $\mathrm{r}$ & & $\mathrm{D}$ & \\
\hline 78. & Eryngium & & $r$ & & & & $\mathrm{i}$ & $r$ & & & & & & & & & & & & $r$ & & $\mathrm{r}$ & & & & \\
\hline
\end{tabular}




\section{Material and Methods}

The honey samples have been taken from 30 stations located in different regions of Albania. The laboratory processing of the honey samples was done based on the "Methods of Melissopalynology" designed and published by the International Commission for Bee Botany, (Louveaux et al., 1978), by the method of basic fuchsin (Smoljaninova Gollubkova, 1953) and acetolysis (Avetisjan, 1950; Erdtman, 1956). The indetification of pollen grains in honey has been done based on the data from the literature Erdtman, 1956; Faegri et al., 1989; Kapidani, 1996; Pupuleku, 2001; Ricciardelli D'Albore, 1998; Moore et al., 1978, Ferrazi et al., 1990, Ricciardelli D'Albore et al., 1991).

The quantitave pollen analysis were conducted based on the pollen frequency classes as follows:

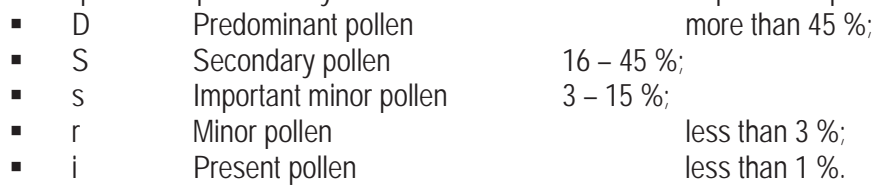

The pollen spectrum and the comparative one of the honey studied were designed based on the above frequency classes.

The studied stations were as follows:

\begin{tabular}{|c|c|c|}
\hline 1. Kukës & 16. & Cermenikë \\
\hline 2. Bajram Curri & 17. & Rrajcè \\
\hline 3. Pukë & 18. & Korçë \\
\hline 4. Koplik & 19. & Prespë \\
\hline 5. Mat & 20. & Starovë \\
\hline 6. Burrel & 21. & Ersekë \\
\hline Lezhë & 22. & Voskopojë \\
\hline 8. Krujë & 23. & Tepelenë \\
\hline 9. Priskë & 24. & Mallakastër \\
\hline Krrabë & 25. & Libofshë \\
\hline Elbasan & 26. & Divjakë \\
\hline Gjinar & 27. & Alarup \\
\hline Gramsh & 28. & Gjirokastër \\
\hline Librazhd & 29. & Llogara \\
\hline 15. Steblevë & 30. & Sarandë \\
\hline
\end{tabular}

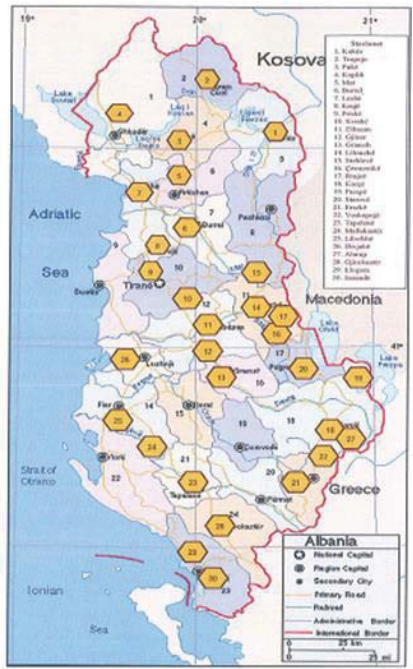

Figure 1. The map of the studied stations

\section{Results and Discussions}

Table 1. The pollen and comparative spectrum of honey samples studied

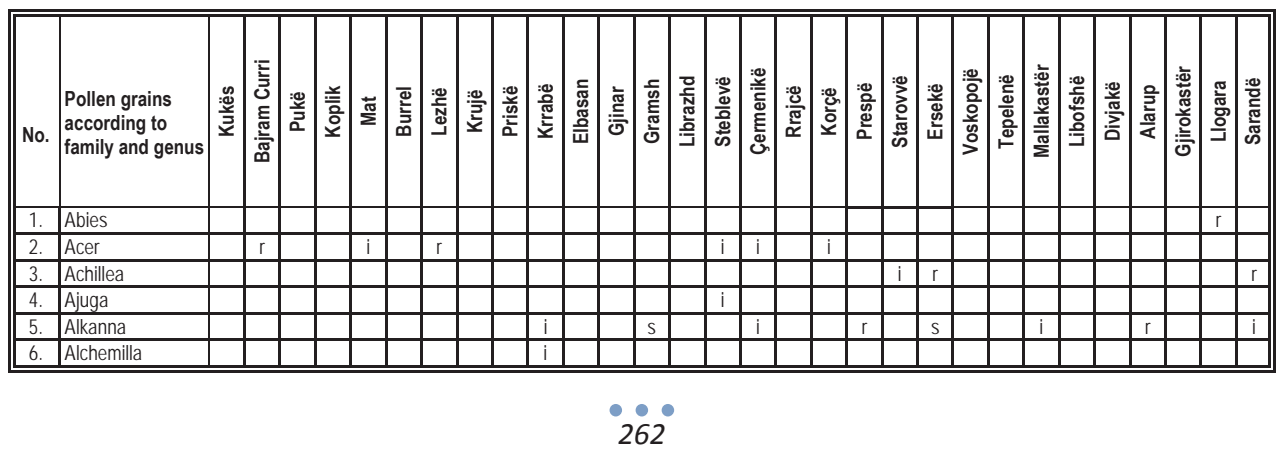




\title{
Melissopaynological Study of Albania's Honey
}

\author{
Ass. Prof. Blerina Pupuleku ${ }^{1}$ \\ Prof. Gëzim Kapidani² \\ Ass. Prof. Peçi Naqellari' \\ Dr. Ermelinda Gjeta ${ }^{1}$ \\ ${ }^{1}$ Department of Biology, Faculty of Natural Sciences, Universitety "A. Xhuvani” Elbasan, Albania \\ ${ }^{2}$ Department of Biology, Faculty of Natural Sciences, University of Tirana, Albania \\ Email: blerina.pupuleku@hotmail.com
}

Doi:10.5901/ajis.2016.v5n3s1p261

Abstract

A total of 30 samples of honey were collected from the beekeepers throughout different regions of Albania and analysed for their pollen grains content and control of botanical origin. Honey sediments obtained from honey samples were processed based on the method of basic fuchsine and acetolysis. Quantitative and qualitative analysis of pollen grains in honey was done based on the methodology given by Maurizio and the terms of the pollen grains frequencies approved by the International Commission for Bee Botany. 16 out of 30 samples of honey were polyfloral and the rest unifloral. The majority of monofloral honey was characterised by the presence of genus of Castanea, Arbutus and Erica pollen. The presence of few pollen grains of genus such as Tilia, Rubus and Artemisia, were identified in only one honey sample. It was concluded that the most preferable plants for the bees are those of the genus of Erica, Arbutus, Castanea, Artemisia, Tilia, Rubus, Lotus, Trifolium, Filipendula, Crepis, Thymus, Quercus, Rosa, Centaurea, Coronilla, Anchusa etc.

Honey samples collected from different regions of Albania were natural, pure and unprocessed termically.

Keywords: Pollen grains, pollen frequency, melissopalynological analysis, monofloral and polyfloral honey.

\section{Introduction}

Melissopalonological studies are necessary not only to identify the natural, geographical and botanical origin of honey, but also to identify the contamination of honey with certain elements such as: brood, dust, soot, etc.; yeast content (fermentation); and other microscopic participles not usually present in honey.

The determination of the botanical origin is based on the identification and counting of the pollen grains. The presence of the other elements is also important to be investigated and counted. Based on the fact that the value and the quality of honey mainly depend on the variety and quantity of its pollen grains, their presence in honey is an element that shows its pureness.

Numerous qualitative and quantitative data were produced by this study about the presence of the pollen grains in honey provided by bee-keepers from 30 stations located in different regions of Albania, during the period of time 20152016.

The object of this study was the identification of variety and quantitative content of pollens in some honey samples taken from different regions of Albania, by the melissopalynological analysis.

This study aims to:

- Determine botanical origin of honey in different regions of Albania through a melissopalinological study;

- Determine the most important plants in Albania, preferred by honey-bee as main food source;

- Determine naturalness and quality of Albania's honey; and

- Induce responsible institutions that certify the quality of honey to set and implement market standards, and protect customers from false honey. 
Makower, Thomas \& Schuler, (1995) "Managing diversity in the workplace" Business and society Review

McKenna, L. (2009) Moving beyond adversarial relationships, Canadian Business Review , 22 (2), Summer, pp. 25-7.

Melander, E. (2005) Gender Equality and Intrastate Armed Conflict. International Studies Quarterly, 49, 695-714.

Morrison, A., Raju, D. and Sinha, N. (2007) Gender Equality, Poverty and Economic Growth. Policy Research Working Paper. The World Bank, Washington.

Nolte, I., Danjibo, N., and Oladeji, A. (2010) Religion, Politics and Governance in Nigeria. Religions and Development Research Programme, Working Paper 39. University of Birmingham.

Olojede Iyabo (2009), "Women: The Neglected Force in Public Administration" $2^{\text {nd }}$ Inaugural Lecture of the Faculty of Management Sciences LASU Ojo.

Ugwulebo, B.A. (2011) Female Gender in Professional Education. Marketing and Management of Professional Survey Education.

UNDP (2012), National Human Development Report 2012 www.ng.undp.org

UNDP (2014) National Human Development Report 2014. www.ng.undp.org

UNESCO (2014) World Data on Education. 2011-2015.

United Nations Economic Commission for Africa (UNECA) (2002) Africa Women's Report 2002.

World Bank. (2009) School Education in Nigeria: Preparing for Universal Basic Education. Africa Region Human Development Series. No 53. The World Bank, Washington. 
done. Given their obvious prospects, women inclusion in the development process is a primary means of vibrant socioeconomic change.

\section{Recommendations}

To enhance gender parity, male-centred structures must be diminished to guarantee equal access. Egalitarian standards must constitute the foundation of early socialization of children to break traditional attitudes and stereotypes. Females must contend alongside males for posts to manipulate civic rules regulations and laws in their support knowing that, control cannot be prearranged for them just like that. Funding agencies must encourage more collaborative research on diverse aspects of gender disparities to attain sincere egalitarianism between males and females in the rule procedure. The few women already in high positions must demonstrate positive role modelling and mentor younger ones. Research and training programmes and efforts in the area of women studies should be intensified while gender training and orientation must be promoted.

\section{Conclusion}

This paper presents a broad situational analysis of gender parity in Nigeria and considers development in significant aspects like: employment, education, earnings, poverty and political representation. It ascertains that females experience methodical drawbacks plus iniquitousness specifically more grievous for individuals in the more deprived states and zones of the nation. The country's 80.2 million females boast considerably poorer lifetime prospects compared not only to males but even other females in similar nations. Nevertheless women constitute Nigeria's concealed resource and empowering women and girls has the prospect of boosting national productivity now in addition to encouraging sustainable growth, peace and development. It consequently advocates plans and strategies aimed at improving the lifestyles of the females. Disparity hurts social unity and could intensify conflict, particularly when particular societal clusters are distinguished as being barred from chances. Conflict negatively affects women and girls, diminishing their freedom of movement and hindering their contribution to social, economic and political life.

\section{Refernces}

Badmus, Isiaka Alani (2015) "Political Parties and Women\&\#39;s Political Leadership in Nigeria: The Case of the PDP, the ANPP, and the AD", Ufahamu: A Journal of African Studies/00415715, 20060301

British Council Nigeria (2012) Gender in Nigeria Report www.britishcouncil.org.ng

British Council Nigeria (2012) Gender Equality Report www.britishcouncil.org.ng

British Council Nigeria (2013) Gender Impact Report www.britishcouncil.org.ng

British Council Nigeria (2014) Gender Impact Report www.britishcouncil.org

Caprioli, M. (2005) Primed for Violence: The Role of Gender Inequality in Predicting Internal Conflict. International Studies Quarterly 49, 161-178.

Corbridge and Pilbeam (2010), People Resourcing and Talent Planning: HRM in Practice.researchportal.port.ac.uk

Cox, T. O'Neill, P and Quinn, R (2001) Effects of Labour Market Institutions and Establishment Characteristics on Gender Wage Inequality in Africa: Evidence from Industry Survey Data in Nigeria. International Journal of Sociology and Social Policy. Vol. 18, No. 9/10, 309-325.

Daudia, R.O.S. (2007) Female Education and Nigeria's Development Strategies: Lots of Talk, Little Action. Indian Journal of Gender Studies, Vol. 14, No. 3, 461-479.

Fapohunda, Tinuke M. (2012) "Gender and Development: Challenges to Women Involvement in Nigeria's Development." International Journal of Academic Research in Business and Social SciencesVol. 2 Issue. 6. June 2012. Human Resource Management Academic Research Society, USA.

Fapohunda, Tinuke M. (2013) "The Gender Pay Gap in Nigeria: Causes and Remedies" Mediterranean Journal of Social Sciences Vol. 4, No.2, 2013. Mediterranean Center of Social and Educational Research University of Rome, Italy.

Halkias, et al. (2011) Challenges facing women entrepreneurs in Nigeria. Management Research Review, 34(2), 221-235.

Hunt, F. (2008) Dropping out from school: a cross-country review of literature. CREATE Pathways to Access, Research Monograph No. 16, May 2008.

Iheduru, N.G. (2006) Women Entrepreneurship and Development: The Gendering of Microfinance in Nigeria. Paper presented at the 8th International Interdisciplinary Congress on Women, 21-26 July 2002 at Makerere University, Kampala.

International Labour Organization (2006) World Employment. www.lo.org/public/english bureau/inf/pkit

Loden, M., and Rosener, J.B. (2009), Workforce America! Managing Employee Diversity as a Vital Resource, Burr Ridge, IL: Irwin.

Mahdi, S. (2011) Position Paper on the Political Context for Development and Gender Equality in Nigeria. 
income. Besides, a gender prejudice in allocation of income tax payments implies that female taxpayers are burdened unreasonably. The substantial pay inequity between males and females in Nigeria reveals their unequal chances to make a living. The report again affirms that as Okpara (2004) opines, additional pay discrepancies can be attributed to workplace gender discrimination in both the private and public segments. The British Council Nigeria Gender Impact Report (2014) quotes Oyelere (2007) as indicating that in 2007 males got on average about N2, 300 monthly more than females and the earnings gap increased at least US\$23 monthly at this time. This comparison of the earnings of males and females with similar levels of education indicates that, females at all scholastic levels make less than their male colleagues and sometimes males with less education receive higher pays than more educated female colleagues. A conduit to female empowerment is training and employment. In Nigeria, it is obviously somewhat complex to improve earnings simply through scholastic criterions; structural barricades must move prior to education making a change for women. Morrison et al. (2007) emphasizes the price of inequity and contend that it is excellent economics to guarantee income uniformity amongst males and females.

\subsubsection{Gender Disparities in Poverty}

The British Council Nigeria (2013) affirms that irrespective of the substantial affluence and resources in the country, 54\% of the inhabitants of Nigeria live in poverty. In Nigeria, the woman is employed in agriculture, informal income generating activities, health and education, all tasks essential to society's continued existence but many of them live in poverty. Fapohunda (2013) affirms that poverty takes a female face the female's particular poverty is a great deal more encompassing than the poverty of the male and this not only intimidates nationwide subsistence and well-being but constitutes is a challenge to sustainable development. The UNDP (2013) indicates that $70 \%$ of persons in poverty are females and adds that for Nigeria, returning to democratic rule in 1999 improved the country's chances for development. Nonetheless remarkable progress has not occasioned employments besides a great deal of the prosperity engendered is controlled by a small number of persons with about $50 \%$ of the population grasping at just $10 \%$ of total national income. UNDP (2012) notes that between 1998 and 2011, inequity in Nigeria aggravated from 0.43 to 0.49 . The nation was thus positioned in the midst of those with the utmost inequity levels globally. The poverty challenge in the nation is somewhat an element of extraordinary disparity that is evident in very disparate pay dispersal and discrepancies in access to rudimentary structure, training, teaching and employment prospects. Bearing in mind, the now recognized connection between female earnings and household results, the examination of gendered poverty brings up a probe into the number of children that can conceivably be elevated out of lack and indigence with the realization of gender equality. Obviously the price of gender inequity in Nigeria is significantly greater than frequently supposed.

\section{Efforts at Achieving Gender Parity}

The search for women recognition has always been misconstrued and misinterpreted to imply physical or biological equality but the contemporary thinking is not about that kind of equality but the equality of recognition given to every individual human-being as equal before God, the law, and human beings. Equal value must be attached to every individual's contribution in society not considering their sexes.

The convention for the Elimination of every type of Discrimination against Women (CEDAW) was approved over thirty years ago by the United Nations General Assembly, and Nigeria was one of the countries that ratified it. The Convention obliges member nations to follow a regulation of removing by all means discrimination against women through very suitable methods and devoid of deferment, to re-affirm the parity of constitutional rights for females in the community and the household, take the plunge against societal foundations of female inequity and to eradicate laws, labels, traditional practice and preconceptions that harm women's wellbeing.

Again, the Nigerian Constitution assures females' parity with males. Section 17 (1) of the Constitution affirms that 'the Federal Republic of Nigeria will be founded on the values of independence, egalitarianism and social fairness'. Nigerian citizens will not to be bestowed any privilege or benefit that is not conferred to other nationals of Nigeria of other national groups and, interalia, gender. As Olojede (2009) points out the motivating standard presumable from the Nigerian legitimate provisions is that of equal opportunity for men and women under the law. Officially, women are entitled to equivalent positions with men in policymaking institutions like boardrooms, legislature and managerial committees. In recent times, some attempts to re-emphasize and acknowledge the significant role of gender parity in national development have been made. These include the creation of the Women Affairs Ministries at both National and state basis and the inclusion of more women in past and current administrations, however quite a lot still needs to be 
government again engaged 750 people in 137 federal boards just 68 of whom were females. Only 11.3 per cent of cabinet members are women, there is only one elected female governor, 1.1 per cent women councillors, 1.2 per cent local government chairperson, 2.8 per cent senators and 3.3 per cent representation at the House of Representatives. While some modest improvement has been recorded, the percentage of women representation is far below the anticipated 30\% representation of the Affirmation Action principles and the principles contained in the national policy for women. Okpara (2004) contends that a quick investigation of the pattern of women who contest elections expose that the greatest numbers of these women, either by objects of biological or marital indices enjoy dominant political connections with influential politicians. While some level of progress has been achieved so far in improving the social, cultural and material well-being of women, not much has been achieved in the area of political leadership. Consequently, politics is still a male dominated area and very few women have ventured to play active roles in politics.

\subsubsection{Gender Disparities in Employment}

The recent economic downturn in Nigeria added to the abyss between employment generation and the progression in the volume of job hunters have combined to aggravate the unemployment condition both for women and men. Nevertheless, a 2012 study by this author found that women countenance superior susceptibilities in the job market owing to factors like their comparative inadequacies in schooling and training, the inclination to guide females into particular occupations, the incessant substantial encumbrances arising from free domestic labour, having children and caring for the children, all of which limit the period and vigour left for pay-earning activities.

UNDP (2014) posits that females have about $67 \%$ fewer chances compared to males of getting wage occupations and only about $30 \%$ of 10 females in Nigeria's labour force are paid employees. Fapohunda (2012) notes that between 1970 and 2009; the formal sector involvement rates for females fell from 57 per cent to 53 per cent. 2.5 million females were retrenched from their jobs between 1985 and 2000 as upshots of the Structural Adjustment Programme. Although they were only 6 per cent of formal sector workers cut back, women accounted for 31 per cent of the cut back workers. Women had controlled the poorer strata of the social services sector, which encountered the fullest budget censors. Many of such retrenched women relocated to the informal sector. Fapohunda indicates that the non-agrarian informal segment today engages up to 25 per cent of the female workforce, customarily in petty trading and home-centred processing and manufacturing, which are characterised by poor access to approved means of credit or data. Moreover, these female employees never enjoy the gains of minimum pay and social security endowments and are obliged to cater for their own health and superannuation needs. Consequent on the decline of formal sector employments, the informal sector has developed into a "safe haven" for women due to its small capital requirements and simplicity of admission. For most females, involvement in the informal sector constitutes a subsistence tactic, even if they still encounter firm opposition from fresh players, including males who are unable to get formal sector work.

Overall, though, women's poor access to inexpensive credit, materials, technical assistance and facilities inhibits them from growing their businesses. The informal area where females prevail is typified by little efficiency and camouflaged joblessness. The British Council Nigeria (2013) acknowledges that in Africa, Nigeria possesses one of the bottom ratios of female private enterprise because the greatest numbers of females are focused in unplanned, littleexperience, small waged informal sector work. Moreover UNDP (2014) notes that only a mere $7.2 \%$ of females are owners of the properties they cultivate, a situation which reduces their ability to obtain credit and limits free enterprise and commercial actions.

\subsubsection{Gender Disparities in Earnings}

Gender wage disparities involve the comparative variances in the normal gross incomes of males and females in an economy. There is agreement that there are gender wage dissimilarities contrary to females and supportive of males. Equal pay law was announced in the Nigeria over four decades ago. Gender parity law was additionally strengthened by the 2007 Gender Equality Duty relating to all public bodies and aspects of the 2010 Equality Act. However, UNDP (2012) specifies that Nigeria's gender wage gap constitutes one of the topmost globally and females are undersold in the belter paid, more commanding places. Significant rural-urban differences in income distribution impact particularly on women, because as the British Council Nigeria Gender Impact Report (2014) indicates, 54 million out of Nigeria's 80.2 million females dwell in and are employed in the countryside regions, where they offer $60-79 \%$ of the country workforce. World Bank (2009) submits that an assortment of impediments, such as procreative responsibilities, meagre access to creative assets, and difficulties concomitant with poor levels of education, collectively explain the observed gender disparities in 
rural infrastructure and services; besides state capitals both in the North and the South seem to exhibit improved conditions compared to the smaller cities in their provinces.

\subsubsection{Gender Disparities in Education}

Nigeria is characterized by gender inequality in registration equally in the primary and secondary levels of education and this according to Dauda (2007) hinders it from garnering its demographic dividend. Primary school registration numbers have wavered a bit in the recent past. Dauda affirms that once the numbers achieved a pinnacle in 2010, they have since continued to be somewhat stagnant. UNESCO (2014) puts the current net attendance ratio at $61 \%$. This is troubling since it still falls short of the EFA goal of putting all children of school age in school.

The British Council Nigeria (2013) also observes that Theobald et al., (2012) posits that Nigeria still has additional youngsters of primary school age who are unfortunately not in school compared to any other nation in the globe. Again the 2015 Nigeria Education Data Survey indicates that about 1.8 million kids ( $8.1 \%$ of kids aged $6-14$ ) were out of school during the period of the study. Of this, almost $61 \%$ were girls. While the gender gap seems to be closing, the total registration proportion of girls remains ominously poorer when compared to that of boys. Also, girls' finishing rates are usually lower than that of boys. UNESCO (2014) indicates that in some Northern States, confirmed girls' finishing rates are as low as 7.8\%. Mahdi (2011) asserts that a common causative social factor is that some parents have a predilection for their male children to attend school since daughters neither take over nor continue the family name. Hunt (2008) attributes the very low finishing rates to a permutation of factors like: parental condemnation of the secular curriculum; user costs; bullying and early marriage. Again, most girls who finish primary school do not proceed to secondary school. UNESCO (2015) puts the net enrolment rate for girls in the North at 22\%. The British Council Nigeria (2012) Gender Equality Report avows that over $80 \%$ of females in eight of the Northern States are incapable of reading (compared with $54 \%$ for men). It also suggests for instance that in Jigawa State, $94 \%$ of women (42\% of men) are not literate. The continued comparatively poor enrolment and elevated dropout rates is disheartening bearing in mind the significance of education for Nigeria's future.

\subsubsection{Gender Disparities in Political Participation}

Virtually all segments of human development are characterized by an absence of gender equality. Despite the fact that women form approximately one half of the Nigerian populace, their involvement in democratic structures and procedures remain insignificant as a result of gender inequalities in the political arena. Governance has always been about power. It is the power or personality to dominate a group. Males have been in control of power and leadership in the world and rooted labels about females have barred females from occupying their lawful positions as equivalent companions. Nation building requires the effective and efficient mobilization of available human (irrespective of gender) and material resources. The male gender controls government thus holding the reins of power relations and exerting sole authority over resource allocation and control.

Melander (2005) contends that worldwide practice campaigns that better female governmental involvement is related to reduced degrees of intrastate and local wars and violence. The United Nations Economic Commission for Africa (UNECA) (2002) states that "....... If all people were allowed to share the opportunities available, development will be achieved at the most rapid rate possible. Women constitute the mass of persons on the electoral rolls during voting, exhibit considerable attendance at political campaigns, and meetings as enthusiasts and performers, but they are seldom duly registered members of political parties and they hold minority party posts or political positions. in Nigeria, women's involvement in politics are limited by quite a few dynamics including: discriminatory socio-cultural practices; economic or financial factors: the violent nature of Nigerian politics; the part of socialization in the relegation of females; lack of educational opportunities which also constitutes a major hindrance to effective political participation by females. Badmus (2015) attests to the fact that in Nigeria's 2015 General Elections, among the 52 million qualified enumerated voters, females made up about 32 million nonetheless only a mere $2.34 \%$ of them won elections. Women membership of political parties as shown in party registers in 2015 was $5 \%$, party executives who were female was $7 \%$ while females who made it to party representatives were $8 \%$. In this current and $8^{\text {th }}$ National Assembly, there are only 7 females out of 109 Senators, 12 females out of the 360 House of Representative Members, 18 females out of the 990 State House of Assembly members, 143 females out of the 8810 Local government Councillors, and 11 females out of the 774 Local Government Chairmen. A similarly low drift is continual in appointive posts. Just 5 females were among the ministers and presidential advice-givers signed up in 2015; and of the 52 ambassadors merely 4 females made the list. The federal 
Gender stereotyping is so entrenched in the Nigerian culture, it is frequently imperceptible. Discrimination commonly happens arising from ignorance rather than premeditated or malicious intent but knowledge obliterates ignorance and reduces stereotyping. This paper gives a situation analysis of gender parity in Nigeria and examines the significant issues that require tackling in order to exploit the prospects of females. It concentrates consideration on the dire issues and depicts the seriousness and importance of the situation. It therefore calls attention to analysed behaviours with a new awareness of gender differences with the aim of educating stakeholders, and training individual team members for inclusion and excellence.

\section{Literature}

\subsection{Diversity}

Cox, O'Neill and Quinn (2001) sees diversity as the differences in social and cultural identities amongst people existing together in a defined system. Loden and Rosener (2009) perceives it as the mass individual dissimilarities and similarities that exist between people. Mckenna (2009) denotes it as discriminatory and non-inclusive behaviours with psychological foundations. Corbridge and Pilbeam (2010) delineates it as dealing with a person or group of people with a reduced consideration because of incapacity, race, religious conviction, age, sex or sexual alignment or by applying certain conditions or requirements that are more easily satisfied by one group than another. The International Labour Organization (ILO) (2006) distinguishes diversity as the demographic differences in the workforce of an organization or nation. Human beings come in assorted shapes, sizes, opinions and colours and this assortment symbolizes the core of diversity. Diversity necessitates nations assuming novel ways of managing and valuing it. Instead of pitting groups against each other, leaders must endeavour to identify the distinctive differences and contributions of each individual and group to national goals and objectives.

\subsection{Gender Parity in Nigeria}

Nigeria demonstrates extraordinary and disturbing depths of disparity. The British Council Nigeria (2012) reports that Nigeria is today catalogued as a lower middle-income nation. A major challenge currently facing the country involves creating viable employment generating development and reinforcing establishments, to support culpability and facilitate fair sharing of the profits of that development. The report adds that except inequity is addressed urgently, it possesses the prospect of breeding and aggravating disputes. British Council Nigeria also alludes to Filma (2008) which avows an association among gender inequity, additional systems of unfairness and clashes in the particular environment of the political economy of Nigeria. Furthermore, Caprioli (2005) and Melander (2005) and Iheduru (2006) all distinguish a link between gender egalitarianism and intense intrastate wars. This relationship underscores the significance of appreciating and tackling gender relations.

\subsection{Components of Gender Gaps in Nigeria}

According to the Gender in Nigeria Report (2013), the inability of majority of Nigerian women to add extra to family monetary earnings reduces their capacity to impact expending at domestic level and limits their capability to add to financial development. Hardly any rural or metropolitan women possess land, consequently finding it tougher to advance monetary assets. Moreover, women are less in formal sector employment, but are rather refined in the microenterprise segment.

Both in the terms of inputs they make to development and the advantages they receive from it, females in Nigeria remain the underclass and are deficient in equivalence of prospect. While education, class, ethnicity, kinship, marital status and religion frequently alleviate or complicate the result, the story is correct of all women in Nigeria. Nolte et al. (2010) contends that since 1999 and the political open-mindedness which permitted a superior grade of liberty of worship, the religious element has gained additional importance. An imperative element of the fight for gender parity as The British Council Nigeria (2012) quoting Edozie (2007) asserts is the environmental dissection between the North, with mostly Muslims, as against the South, with primarily but not wholly Christians.

Added to the North- South segregation (since the people in the industrial South are inclined to manifest better conditions than the ones living in the North) is the rural-urban segregation in all parts of the country. Reminiscent of most of Africa, urban areas tend to be characterized by improved quality of life arising partly from insufficient investment in 


\title{
Diversity and Gender Parity in Nigeria: A Situation Analysis
}

\author{
Fapohunda, Tinuke $M$. \\ Department of Industrial Relations and Personnel Management \\ Lagos State University Ojo, Nigeria \\ Email: tkfap@yahoo.com
}

\section{Doi:10.5901/ajis.2016.v5n3s1p254}

\begin{abstract}
Diversity as a subject has received increased interest in modern times and all and sundry appears to be speaking about it, there doesn't appear to be much actual progress. Contemporary studies confirm that more novel problem-solving and superior decision-making arises when diverse views and perceptions are incorporated in a shared pool of knowledge. Consequently, ineffectiveness in diversifying work teams especially with respect to gender portends the risk of losing the war on talent. Nigeria's population of about some 170.5 million people constitutes the largest population of any African country. Of the vast population, females constitute 49\%; about 82.2 million females. Consequently, all discourses on Nigeria's prospect should inevitably involve contemplation of females, their position and those obstacles they face in making the future. Generating a gender sensitive nation obliges deliberate, continuous effort. To sustain inclusion initiatives, gender diversity must be embedded into the fabric of the country. Progressive management is now more than a "one size fits all" approach; it demands a grasp and endorsement of the characteristic values and point of views individuals bring to the table. Women and men bring diverse, but homogeneously vital benefits to the national development. Subsequently, discerning leaders must promote their consciousness of the disparities and build an atmosphere where both are embraced and respected. Gender stereotyping is so entrenched in the Nigerian culture, it is frequently imperceptible. Discrimination commonly happens arising from ignorance rather than premeditated or malicious intent but knowledge obliterates ignorance and reduces stereotyping. Undoubtedly women are Nigeria's unseen resource and advancing their cause increases productivity, encourage sustainable growth, peace and improved health. This study presents a situation analysis and examines the significant issues that require tackling in order to exploit the prospects of females. It emphasises the serious issues and depicts the seriousness and importance of the situation. It therefore calls attention to analysed behaviours and with a new awareness of gender differences with the aim of educating stakeholders, and training individual team members for inclusion and excellence.
\end{abstract}

Keywords: Diversity, Gender, Parity, Situation, Analysis

\section{Introduction}

Diversity involves dissimilarities or variations between individuals arising from ethnicity, age, race, belief, sexual alignment, socio-economic grouping, gender, and abilities/incapacities. It elevates important ethical concerns and social representative issue as well. Current competitive global milieu presents many significant tests to build competitive advantage by boosting competence, excellence, originality and sensitivity added to the management of a diverse citizenry. Diversity is crucial to exploit the talents of individual from varied backgrounds, because as Makower, Thomas and Schuler (1995) affirm, their dissimilarities deepen, expand and provide the competitive edge. Consequently, countries aiming for improved national development and the competitive edge must engage a variety of people and exploit them. Interestingly though while there has been talk about it, not much seems to be seen in terms of making legitimate progress by effectively ensuring gender balance in Nigeria irrespective of the fact that the last two decades at least, has witnessed various contributions in gender diversity seminars.

Contemporary studies like Ugwulebo (2011) and Halkias, et al. (2011) validate that more innovative problemsolving and superior decision-making occurs when diverse views and perceptions are included in a shared pool of knowledge. Consequently, countries that fail to diversify their leadership teams especially with respect to gender stand the risk of losing the war on talents. Generating a gender diverse national management team necessitates intentional, ongoing effort. To maintain inclusion ideas, diversity must be embedded into the fabric of a nation.

Progressive national leadership management is now beyond a "one size fits all" approach; it entails a comprehension and approval of the distinctive merits and outlooks individuals bring to the communal table. Women and men bring diverse, but uniformly important assets to the nation. Consequently, developing countries like Nigeria must elevate their consciousness of the disparities and build an atmosphere where both genders are embraced and respected. 
Gibson, J.(2002), Why does the Engel Method Work? Food demand, Economies of scale and Household Survey Methods. Oxford Bulletin of Economic $s$ and Statistics.

Houthakker, H.S.(1957) An International Comparison of Household Expenditure Patterns, Commemorating the Centenary of Engel's Law. Econometrica

http://siteresources.worldbank.org/intecaregtoppovred/Resources/AlbaniaPAAlbanianVersion.pdf

Human Development Report 1997, http://hdr.undp.org/en/reports/global/hdr1997/chapters/

Indicators for Monitoring the Millennium Development Goals, United Nations, New York 2003: http://devdata.worldbank.org /gmis/mdg/UNDG\%20document_final.pdf

Instat (May 2014): Albania: Trend in Poverty 2002-2005-2008-2012

INSTAT, "Albania Trends in Poverty", April 2009: www.instat.gov.al

INSTAT, 2013: http://www.instat.gov.al/en/themes/living-standard.aspx\#tabs-5

J.Singh ( $($ ), Notes on Income Consumption Curve and Engel Curve (with curve diagram), Article, http://www.economicsdiscussion.net/cardinal-utility-analysis/notes-on-income-consumption-curve-and-engel-curve-with-curvediagram/1040\#sthash.izDL1Xfy.dpuf

Leser, C.E.V. (1963). 'Forms of Engel Functions', Econometrica

Manigi C. and Moneta A., (2009), More or better? Measuring quality versus quantity in food consumption

Ravallion and Bidani, 1994: "How robust is a poverty profile", World Bank Economic Review

Stone, J. R. N. 1954. "Linear Expenditure Systems and Demand Analysis: An Application to the Pattern of British Demand." Economic Journal 64

The universal declaration for human rights http://www.unicef.org/turkey/pdf/gi17.pdf

Theil, H. 1965. "The Information Approach to Demand Analysis." Econometrica 33

Theil, H. 1983. "World Product and Income." Journal of Political Economy 91

Working, H. 1943. "Statistical Laws of Family Expenditure." Journal of the American Statistical Association

World Bank, (2005), Chapter 4. Measures of Poverty: http://siteresources.worldbank.org/PGLP/Resources/povertymanual_ch4.pdf

World Bank, (2005), Poverty Lines chapter 3: http://siteresources.worldbank.org/PGLP/Resources/povertymanual_ch3.pdf

You, J. (2003). 'Robust Estimation of Models of Engel Curves', Empirical Economics.

Wuensch, K. L. (2014), Binary Logistic Regression with PASW/SPSS: http://core.ecu.edu/psyc/wuenschk/MV/Multreg/LogisticSPSS.doc 


\section{$\mathrm{t}_{\mathrm{v}}(56.637) \quad(104.511) \quad(-34.623)$ \\ (12.584) \\ $(-10.853)$ \\ (25.099) \\ $\mathrm{R}^{2}=0.57$ \\ 61.78yearsch +585.6 urbrur \\ (2012) Rfood $=107410-26803$ Incons+1702Incons2 -192.08 acthhsize -309.9 workinsum +4.41 age - \\ $\mathrm{R}^{2}=0.67$}

Large households and the new one have lowest consumption. A household with children under the fifteen years old has averaged less consumption per capita. Instead, families with a greater number of adults rather than people dependent (as reflected by the variable "low ratio of dependence") have a per capita consumption significantly higher.

Individuals with higher education tend to decrease the food per capita consumption. This maybe is related with the fact that they tend to buy luxury goods. The increase the mean years of school with 1 year will decrease the per capita food consumption with 61.78 leks. Changes in the human capital and increase in the expenditures for education contributes to higher qualified work force and well paid.

Poverty varies by gender of head of household, but it's not significant at $5 \%$ level so we have exclude as influential variable.

As the higher is the age also the higher will be per capita food consumption. From this regression we can produce also other results for the probability of being extreme poor. Maybe further can be produced a bivariate logistic regression using dichotomous dependent variable, 1- extreme poor and 0- non extreme poor.

\section{Conclusion}

The higher share of expenditures goes for food. With the increase of income/expenditures the share for food tends to be lower. Trends on food consumption depended by household composition and other household characteristics. When level of per capita expenditure per month, necessary for an individual to take the minimum amount of calories in one place by age and sex fall under the line of this necessity than this individual is Extreme Poor. The probability of being poor is complex and is closely related with households or national factors. The area is negatively related with the per capita food consumption.

So define the extreme poor with per capita food consumption and conclude that larger household in size, larger average years of school will decrease per capita food consumption. As larger is the number of individuals that works per households, increase of age will increased the per capita food consumption. The changes in social and economic factors this last years, changes in the market of goods and services have the main impact in the micro level. So individuals are less absolutely poor and extreme poor. This decrease year over years is related with market changes and will leave more money to spend for non food products.

The poverty is influencing from demographic factors, households characteristics and social conditions. Analyze the factors that influence individuals conditions is helpful for policy makers to eliminate the level of the people that leave in extreme poverty and achieving the Millennium Developing Goals.

\section{References}

Ahmed et al., (2012), The Prevalence of Poverty and Inequality in South Sudan: The Case of Renk County, Department of Agricultural Economics, Faculty of Agriculture, University of Khartoum, Sudan

Barten, A. P. 1964. "Consumer Demand Functions under Conditions of Almost Additive Preferences."

Browning et al, (1994), "Incomes and Outcomes: a Structural Model of Intrahousehold Allocation," Journal of Political Economy

Bourguignon and Chiappori, (1992) "Collective models of household behavior: An introduction", European economic Review 36, Cagayan, E. and Astar, M. (2012), "An Econometric Analysis of Engels curve: Household food and clothing consumption in Turkey".

Cattaneo, C. (2012), Migrants International Transfers and Educational Expenditure

Chesher, A.D. and Rees, H.J.B (1987)," Income elasticities of demands for food in Great Britain". Journal of Agriculture Economics

Damodar N Gujarati - 2004, Economics - Basic Econometrics - McGraw-Hill, Fourth Edition

Dawoud, Seham D. Z. (2013), Econometric analysis of the changes in food consumption expenditure patterns in Egypt, Department of Agricultural Economics, Faculty of Agriculture, Damietta University, Egypt. "Journal of Development and Agricultural Economics", http://www.academicjournals.org/JDAE

Deaton, A., and Muellbauer, J. (1980). Economics and Consumer Behaviour, Cambridge University Press: Cambridge

Deaton,A.( 1997). The analysis of household Surveys: A Microeconometric Approach to Development Policy.

Econometrica 32

Gao, G. (2010), World Food Demand, Business School, The University of Western Australia 


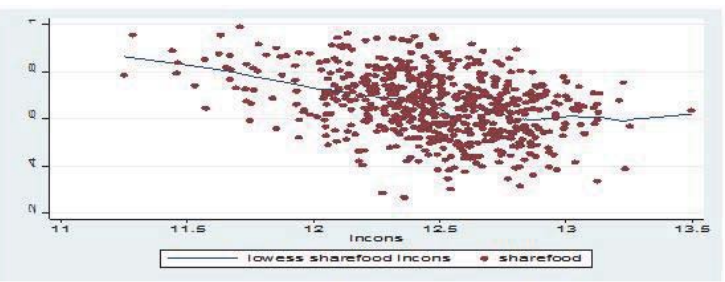

Figure 7: Food consumption of the poor

\subsection{Regression of food expenditures}

The analytical model is lin-log model using the Engel expenditure model.

\section{rfood $=\beta_{1}+\beta_{2}$ Lnrcons $+u_{i}$}

Engel postulated that "the total expenditure that is devoted to food tends to increase in arithmetic progression as total expenditure increases in geometric progression." So $\beta 2=\frac{\Delta Y}{\Delta \operatorname{LnX}}$ is change in rfood over relative change in $\mathrm{X}$.

$$
\frac{d Y}{d X}=\beta_{2}\left(\frac{1}{X}\right) \Rightarrow \beta_{2}=\frac{d Y}{\frac{d X}{X}}
$$

If relative change of $X(\Delta X / X$ relative per capita total consumption) change with $1 \%$ or 0.01 the absolute change of per capita food consumption will increase with $0.01\left(\beta_{2}\right)$, so with $45.16 \%$. Coefficients are statistically significant for $5 \%$ level.

rfood $=-35501.21+4516.29$ Lnrcons $+u_{i}$

$T_{v} \quad(-157.68) \quad(180.67)$

$\mathrm{R}^{2}=56.3 \%$

Some authors have analyzed also other influenced factors to per capita food consumption. (Cagayan, and Astar(2012) n.d.) analyzed the Engel Curve household food and clothing consumption in Turkey. Food costs are the main determinant component of extreme poverty. Thus if we distribute food costs, depending on per capita spending of aligning itself regress linear form but the values are collected in the first quintile-n spending. This graphical form best explains the trend that they should have.

\subsection{Characteristic and significant determinants of beeing extreme poor}

There are some characteristic that define the most important aspect of being in extreme poverty. Based on these factors we have taken in account as the determinant factors that influence the food per capita consumption (dependent). We have take in account per total consumption (Incons), size of the household (Hhsize), age of individuals (Age), average years of school (yearsch), the number of individuals that works per household (workingsum) and one variable dummy for the area (urbrural) code 1-urban and 0-rural (Table 8).

Table 8: Regression of influenced factors to the per capita food consumption

\begin{tabular}{|c|c|c|c|c|c|c|c|c|}
\hline & \multicolumn{2}{|c|}{ Reg1 } & & & \multicolumn{2}{|c|}{ Reg2 } & \multicolumn{2}{|c|}{ Reg3 } \\
\hline & \multicolumn{2}{|c|}{ rfood } & \multicolumn{2}{|c|}{ Rfood/rcons } & \multicolumn{2}{|c|}{ Rfood/rcons } & \multicolumn{2}{|c|}{ rfood } \\
\hline & $\beta$ & P-value & $\beta$ & P-value & $\beta$ & P-value & $\beta$ & P-value \\
\hline Cons & -35501.21 & 0.000 & 2.308 & 0.000 & .425 & 0.442 & 107410 & .000 \\
\hline Lncons & 4516.29 & 0.000 & -.133 & 0.000 & .158 & 0.064 & -26803 & .000 \\
\hline Lncons2 & & & & & -.0112 & 0.001 & 1720 & .000 \\
\hline Hhsize & & & & & & & -192.08 & .000 \\
\hline Age & & & & & & & 4.41 & .000 \\
\hline Yearsch & & & & & & & $-61,78$ & .000 \\
\hline Urbrural & & & & & & & 585,6 & .000 \\
\hline Workingsum & & & & & & & -309.9 & .000 \\
\hline
\end{tabular}


It was estimated the functions of the food shares to the total consumption and to the log of total consumption. The following figures ( 4 and 5 ), show the connectivity and the functional trend. It is estimated the corresponding coefficients to the total and logarithm of total expenditure in the estimated shares, which are reported. The estimates for the expenditure elasticity suggest that food is a necessary good. We have also to see with the other goods like non food and durables classified as luxury commodities or utilities considered also as necessary good. Analysis the cross country influencing factors in short run poverty we saw an increase of it. Economic and social changes that have accompanied this last years have a significant influence in increase of living standard and welfare of the households. There are a set of socioeconomic factors that influence the consumption trend like: changes in wages, mobility of workers (migrations and emigrations) investment, change the workers structure, changes in household composition, changes on income source. These factors have had the positive effect in the decrease of poverty and well being of the households. Analyses these factors will have determinant role in decreasing the absolute poverty and extreme poverty and country development.

An important approach is studying the household composition, household size or number of children. Some countries use equivalent scale to give different weights on consumption children and adults. Based on Engel's second law the food share is an inverse indicator of welfare across households of different sizes and compositions. Another approach is the Rothbarth method which separates the goods of adults by goods consumed by children. In this way measure the standard of living of the adults through calculate expenditure by adults goods. This not uses directly the equivalent scale method. In our consumer, we do not use the Rothbarth method or equivalent scale but per capita consumption that takes on the consideration only the household size. Using Rothbarth method is useful to separate the cost of children as are products that are not consumed by children. We will not go through this method, using equivalence scale. For the moment we will consider as useful the household size. Larger households tend to spend more of their budgets to food than do smaller ones, holding other factors constant. These type of households mostly are households with children.

Thus, according to Engel's second law, the larger household should have a lower food share. But a decline in the food share with constant per capita expenditures can occur only if there is a decline in food spending per person. It is very unlikely that people who are better off would spend less on food, especially in less developed countries. The mean of per capita food consumption consumed on the household with one member is about $1 / 4$ of the total (Figure 7 ).

Table 6: Food shares by household size

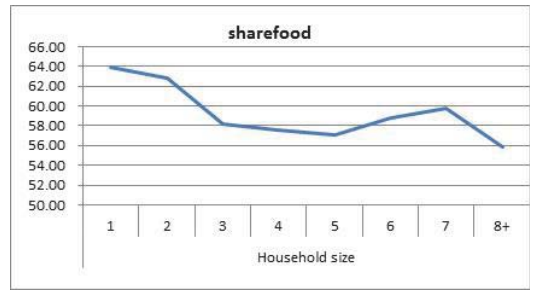

Table 7: The mean of per capita food consumption consumed by household size

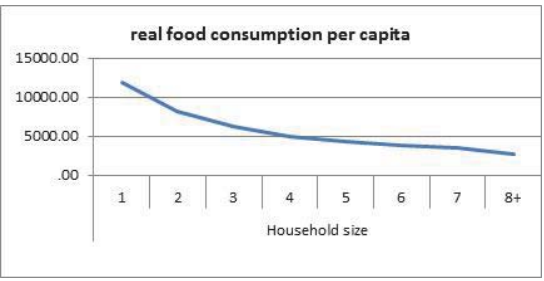

Is expected that households that have the same adults but have a child (calculate child cost), the Engel curve will be up. Some researchers have used the equivalence scales from observed data on household consumption patterns. In this paper we are not going to analyze the different weights used based on household composition. It The differences in demand may reflect the preferences of the adults. Also the demand is influenced by other factors, that why is important trend in food to study with other households characteristics. 


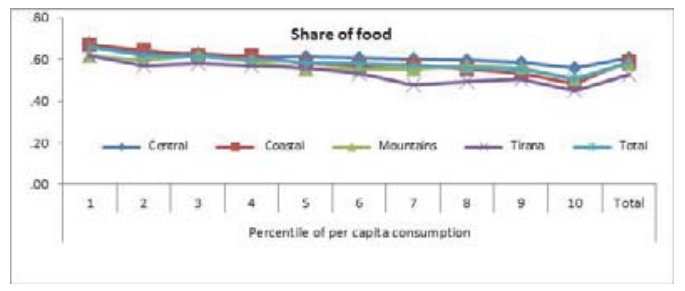

Figure 3: Share of food consumption by region and percentile of total consumption

If we split consumption more, from 5 division to 10, the trend is the same. The per capita food and total consumption increased in the richest people but the trend on share on food decreased significantly and is more visible after the $8^{\text {th }}$ percentile. The difference from the bottom to the top is considered higher.

Region of Tirana has the lowest figures of share of food by percentile of total consumption. To the poor individual they spent the highest percentage on food compared with others and this percentage is almost the same for all regions. The mountain trend is not as was expected, as this has been from years, poorer regions. This is not visible to the trend of consumption as the mountain is in a good position compared with Central and Coastal. Families isolated also have less per capita consumption, though this disadvantage may be disappearing. The definition of isolation here refers to families who are away from social services. Specifically in this case, we measure it with the distance (in miles) from the nearest school.

Capita consumption varies according to residence. The resident in the village or rural area has average less per capita consumption compared to the average per capita consumption of residents in the urban area. Testing if have a significance difference between urban and rural area we need to test $\beta_{6}$ that is equivalent with testing independent two separate regressions we have a significant difference between urban and rural areas. Among the demographic regions there are significant differences in terms of per capita consumption. The population in mountain regions compare with the other regions are much poor and also extreme poor. As the gender of head, the variable stratum ${ }^{2}$ we have excluded from the regression as it is not significant in statistically way at $5 \%$ level.

\subsection{Regression Albanian trend of food consumption}

In the table 1 we present analytically the theoretical concept of the connectivity of food consumption with the total consumption.

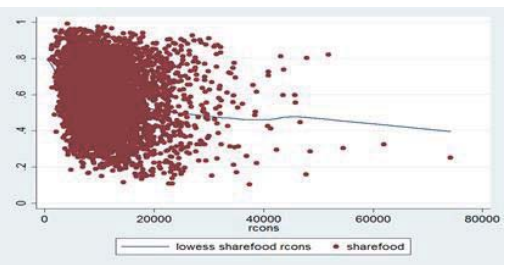

Figure 4: Share of Food consumption by total consumption

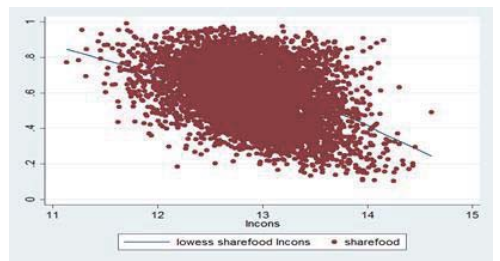

Figure 5: Share of Food consumption by Log total consumption

2 The Albania geographically is divided in four stratum: Coastal, Central, Mountain, Tirana 
Table 4: Share of consumption

\begin{tabular}{|l|c|c|c|c|c|}
\hline & Food & Non-food & Utilities & Education & Durables \\
\hline Coastal & 58.9 & 20.3 & 17.0 & 3.2 & 0.6 \\
\hline Central & 60.7 & 18.5 & 16.7 & 3.5 & 0.6 \\
\hline Mountain & 57.9 & 20.9 & 16.0 & 4.7 & 0.5 \\
\hline Tirana & 52.7 & 22.4 & 21.0 & 3.1 & 0.7 \\
\hline Total & 58.4 & 20.0 & 17.6 & 3.4 & 0.6 \\
\hline
\end{tabular}

\section{Source: INSTAT (LSMS 2012)}

Using Engel curve framework, represent a way to analyze household consumer behavior. It describes how consumer spending behavior varies with income/consumption level, supposing that the prices are held fixed (Cristinna Cattaneo). Studying the trends by quartiles of consumption, going from the level 1 to the level 5 the mean food consumption increased, while the share of food decreased. The ratio of Q5/Q1 per capita food consumption is about 3.2 times higher and the share of food consumption has around 10 point percentage differences from the first to the fifth quartile. This means that in the highest level of consumption, or the rich people tend to spent less on food.

Table 5: Mean of food consumption and share of consumption by per capita consumption quartiles

\begin{tabular}{|c|c|c|}
\hline Quartiles of consumption & Mean food consumption & Share of food consumption \\
\hline First & 2679 & 63.8 \\
\hline Second & 3703 & 60.7 \\
\hline Third & 4569 & 58.2 \\
\hline Fourth & 5796 & 56.3 \\
\hline Fifth & 8526 & 52.9 \\
\hline Total & 5055 & 58.4 \\
\hline
\end{tabular}

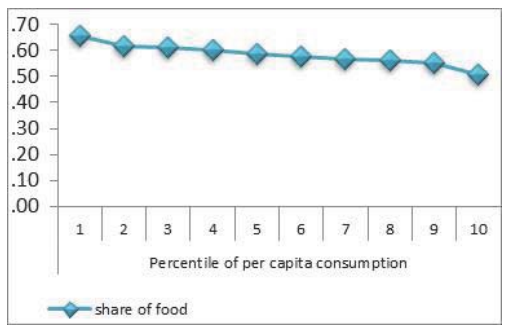

Figure 1: Share of food consumption by percentile of total consumption

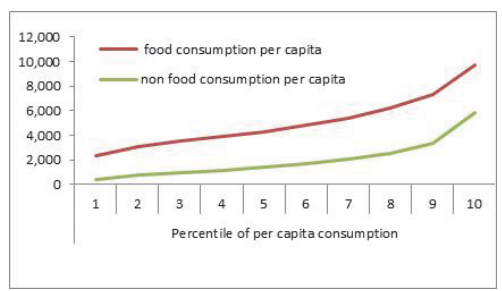

Figure 2: Food and non food consumption by percentile of total consumption

Corinna Manig,C. and Moneta,A. (2009) underline than as people become richer they get the opportunity of consuming more but also qualitatively better goods. Based on Engel's law as households became wealthier, their budget share for food is on average decreasing. 
Table 1: Engel curve method

\begin{tabular}{|c|c|c|c|c|}
\hline \multirow{2}{*}{ No } & \multirow{2}{*}{ Author } & \multirow{2}{*}{ Function } & \multicolumn{2}{|l|}{ Coefficient } \\
\hline & & & Albanian function & $p$-value \\
\hline 1 & Lluch et al. (1977) & $Y_{i}=\alpha+\beta X_{i}+u_{i}$ & $\mathrm{Y}_{\mathrm{i}}=812+0.477^{*} \mathrm{X}_{\mathrm{i}}+\mathrm{u}_{\mathrm{i}}$ & $<5 \%$ \\
\hline 2 & & $Y_{i}=\alpha+\beta \ln X_{i}+u_{i}$ & $Y_{i}=-34093.9+4358 * \ln X_{i}+u_{i}$ & $<5 \%$ \\
\hline 3 & & $Y_{i}=\alpha+\beta 1 / X_{i}+u_{i}$ & $Y_{i}=8575-2.49 * 1 / X_{i}+u_{i}$ & $<5 \%$ \\
\hline 4 & Working (1943) & $\ln Y_{i}=\alpha+\beta X_{i}+u_{i}$ & $\ln Y_{i}=7.7+7.7^{\star} X_{i}+u_{i}$ & $<5 \%$ \\
\hline 5 & Dawoud, Seham D. Z.(2013) & $\ln Y_{i}=\alpha+\beta \ln X_{i}+u_{i}$ & $\ln Y_{i}=1.025+0.821^{*} \ln X_{i}+u_{i}$ & $<5 \%$ \\
\hline 6 & Working (1943) & $\ln Y_{i}=\alpha+\beta 1 / X_{i}+u_{i}$ & $\ln Y_{i}=9.127-+5132.4 * 1 / X_{i}+u_{i}$ & $<5 \%$ \\
\hline 7 & & $Y_{i} / X_{i}=\alpha+\beta X_{i}+u_{i}$ & $Y_{i} / X_{i}=0.656-8.08 X_{i}+u_{i}$ & $<5 \%$ \\
\hline 8 & Working, 1943, Leser, 1963 & $Y_{i} / X_{i}=\alpha+\beta \ln X_{i}+u_{i}$ & $\mathrm{Y}_{\mathrm{i}} / \mathrm{X}_{\mathrm{i}}=1.335-0.084 \ln \mathrm{X}_{\mathrm{i}}+\mathrm{u}_{\mathrm{i}}$ & $<5 \%$ \\
\hline 9 & & $Y_{i} / X_{i}=\alpha+\beta 1 / X_{i}+u_{i}$ & $Y_{i} / X_{i}=494+493 * 1 / X_{i}+u_{i}$ & $<5 \%$ \\
\hline
\end{tabular}

\section{Trend on Food Consumption}

The paper aims to study the relation of per capita consumption depending on different economic positions of individuals. The paper shows different methods and functions of relationship of food consumption with total expenditures. There are a set of explanatory variables that have a statistically significant impact and are defined as influential factors in extreme poverty.

Based on Instat (Maj 2014), the poverty is increased in 2012 compared with 2008. Normally if the poverty decrease by years, also the share of food will decrease. This means that individuals are better off and tried to spend more for non food products. This doesn't happen from 2008 to 2012 where the poverty increased again (Table 3).

Table 2: The food and per capita consumption in 2012

\begin{tabular}{|lcc|}
\hline Variable & $\%$ & Mean \\
\hline Total consumption & & 8,971 \\
\hline Food & 58.4 & 5,055 \\
\hline
\end{tabular}

Source: INSTAT (LSMS 2012)

The share of utilities has an increase trend by years. The share of education of real per capita consumption is also increased first three survey years. In 2012 is decreased by 0.2 point percent from 2008.

Table 3. Percentage of real consumption per capita by year

\begin{tabular}{|lcccc|}
\hline & $\mathbf{2 0 0 2}$ & $\mathbf{2 0 0 5}$ & $\mathbf{2 0 0 8}$ & $\mathbf{2 0 1 2}$ \\
\hline Food & 64.5 & 59.2 & 57.7 & 58.4 \\
\hline Non-food & 19.4 & 24.5 & 22.7 & 20.0 \\
\hline Utilities & 12.6 & 12.7 & 15.2 & 17.6 \\
\hline Education & 2.3 & 2.7 & 3.8 & 3.4 \\
\hline Durables & 1.2 & 0.9 & 0.5 & 0.6 \\
\hline
\end{tabular}

Source: INSTAT (LSMS 2002, 2005, 2008, 2012)

According to Engel's law, by the income (consumption) increase the proposion that households spend for necessary goods decrease and they tend to spent more for non food products and luxury goods. The poor households or less developed countries tried to spend more for food and necessary products.

We have considered food and utilities are necessary goods, and non food and durables are classified as luxury commodities. The marginal budget share estimates reveals that for a one lek increase in the household budget, on average and ceteris paribus, expenditure on food commodities rises by 0.58 Lek, on non food commodities by 0.20 of a lek, on durable goods by 0.6 of a Lek and on utilities by 0.18 of a lek.

The highest level of share food is for the Central region (60.7\%) and the lowest for Tirana. 
the total expenditure elasticity for different categories of commodities. The expenditures are calculated in household level so the household can be treated as a single entity and all members are assumed to possess unified preferences. The roles of income are constructed by model of expenditures as with this method also are calculated main indicators of poverty and inequality. Also the Engel curve estimates are made using consumption expenditures. Using expenditures instead of income is most common in developing countries. This happened because of grey economy, under reported, easy to declare and less sensitive and also less influenced by sezonality (Dawoud, Seham D. Z., 2013).

Engel curve tend to show the household budget shares allocation to the income or total food expenditures.

Somehow it test the Engel law that poorer households spent a higher share of total expenditure to food,.

In different literatures are presented different models to prove this conection (see Deaton and Muellbauer, 1980). For the models we will the general codification for when with $Y_{i j}$ is coded depended variable (food consumption), $X_{i j}$ for independent variable and $\alpha_{i j}$ and $\beta_{i j}$ parameter. Where " $j$ " is the good and the term " $i$ " is the household. To explain relationship between food and expenditures exist different methods used by different authors.

One method is linear relationship.

You (2003) used models in the study where food, transportation, cigarette and alcohol expenditures were examined with Engel functions. As food is a necessity (Engel's law), its expenditures elasticity is less than one. But how should this elasticity vary with expenditures? Consider the linear Engel curve updated for our country in the form: food expenditure Yij (dependent variable), where $\alpha$ and $\beta_{1}$ are constants and $\mathrm{M}$ is income/consumption (or $\mathrm{X}_{\mathrm{ij}} \rightarrow$ indeendent variable). This is the direct linear form of the food model.

The second model could be linear form but in this case as a dependet variable takind into consideration the share of income/consumption goes for food or the food budget share wi (that is, $w=$ food expenditure $=M$ ). As $w$ falls with income and as the slope coefficient $\beta_{1}$ is a positive constant, the elasticity increases with income. Accordingly, the Engel curve implies that food becomes less of a necessity, or more of a luxury as the consumer becomes more affluent, which violates economic intuition (Theil 1983). When the food consumption elasticity has the tendency to vary over countries or over households, Lluch et al. (1977) found that this elasticity tend to fall as expenditures increased. Although the rise on the income/consumption elasticity appears to be a fundamental flaw, the linear Engel curve have been explained by the linear expenditures function (Stone 1954) and the Rotterdam demand model (Barten 1964, Theil 1965).

Working, (1943) and Leser, (1963), provides another form of the model that is more related with the household utility maximization, budget shares linearly to the logarithm of total household expenditures. $W_{i j}$ or $Y_{i j}$ is the budget share on food or the dependent variable (the ratio of expenditure on food to the total household expenditure), $X_{i}$ is the total household expenditure or dependent variable, $\alpha_{i}$ and $\beta_{i}$ are parameters to be estimated and $\varepsilon_{i j}$ is an error term. An expression for the expenditure elasticity and the marginal budget share for good "j" can be derived from this equation. This model has been popular in cross-country demand studies but it suffers from the defect that for large changes in income, the budget share ultimately becomes negative or larger than unity, which is 1.The basic Working-Leser model has been extended to include other variables assumed to affect the budget shares allocated to the different types of goods (see Deaton, 1997).

Log-lin model form

Working (1943) and later Leser (1963) proposed the log-linear budget share supposing that better fiting this functional form. Houthakker (1957) analysed the income elasticities of 30 different countries for four different expenditure groups. Chesher and Rees (1987) estimated the income elasticity of different food demand with the supposition that price does not change during the period of the survey.

According toEngel's law, the food budget share declines as income/consumption increases. In case that is less than 1 and is most likely to be positive (so that food is a normal good).

Another form is the double logarithmic (log-log) functional form is used to estimate expenditure elasticity. This functional type has proven to be the most appropriate way of estimating the expenditure elasticity of demand because of its simplicity and quite easy estimation and interpretation (Ahmed et al., 2012). Also, expenditure coefficient is the coefficient of elasticity and there is no need of calculation.

Dawoud, Seham D. Z.(2013) analyze trend of Engel curve of Egypt by log-log form. In the latter model, interests and the bargain power may differ among members and the composition of the household income is relevant in explaining expenditure decisions (Bourguignon and Chiappori, 1992; Browing et al, 1994 n.d.). 


\title{
Analysis and Interpretation of Functional Connectivity of Per Capita Food Consumption in Albania
}

\author{
Ruzhdie Bici \\ Phd Candidate, Department of Economics, University of Tirana \\ Email: ruzhdiebici@gmail.com
}

\section{Doi:10.5901/ajis.2016.v5n3s1p245}

\begin{abstract}
This paper presents the analytical model of per capita food consumption as the main determinant component of the measurement of food poverty level (extreme poverty). The model study the relation of per capita consumption depending on a set of explanatory variables that are thought to have a statistically significant impact and are defined as influential factors in extreme poverty. Albanian households spend a considered amount on food products. More than $50 \%$ of the total consumption goes to buy food products. This percentage in 2012, is decreased compared 2002 and have almost one point percent difference compared with 2005 and 2008. Computation: SPSS, STATA
\end{abstract}

Keywords: Engel curve, food consumption expenditure, regressive, poverty

\section{Poverty Measure}

In Albania the poverty is measured through consumption. An individual is considered poor if its level of per capita expenditure falls below the minimum level needed to meet basic needs for food and non food items of this individual. Household consumption is considered to be measured more accurately than income due household hesitate to declare their income, income are influenced more from sezonality or high grey economy. The reference data used in the paper and the only source to measure poverty in Albania is based on Living Standard Measurement Survey. The latest data available are from LSMS 2012. The first LSMS is conducted on 2002 and it is used as a base year to deflate results for other survey years (2005, 2008 and 2012).

Evaluation of poverty based on a multidimensional definition of poverty and not only deprivation of income or consumption, poverty is also defined in connection with not appropriate a series of arrangement of social care that are unrelated with income, such as education, health, issuing authority, using of basic services and infrastructure. Poverty is monetary and non monetary. The monetary poverty is used the cost of basic needs methodology (Ravallion and Bidani, 1994). INSTAT 2014, explain the methodology which first calculates a food poverty line, estimated through minimum of calories and after added a value for non food components for basic necessities. Food costs are the main determinant component of extreme poverty. Thus if we distribute food costs, depending on per capita spending of aligning itself regress linear form but the values are collected in the first quintile-n spending.

Extreme Poverty: The food poverty line is the level of per capita expenditure per month, necessary for an individual to take the minimum amount of 2288 calories per day. Converted in money, the food poverty line or extreme poverty line was set at 3,047 ALL per month. The non food component of the poverty line was calculated disregarding, taking into consideration the percentage of non food expenditure of those households that spend for food consumption an amount approximately equivalent to the food poverty line. The poverty line has been set at 4,891 ALL per month at constant prices (2002) ${ }^{1}$.

Engel curve study the trend and the relationship between food expenditures and total income/expenditures. Engel curves were widely examined by using different econometric methods for different groups of goods.

\section{The Engel Method of Measuring}

In the empirical literature, the estimation of Engel curve has been applied across a wider set of applications, to quantify 
migrants and foreigners in Albania risk taking on the connotation of a public safety, public order and security issue, rather than of a social economic, cultural and worker mobility issue.

- The legislation also requires certain financial and economic guarantees so that foreigners residing, working, studying or conducting other economic, social, humanitarian, religious, cultural or other legal activities in the country do not burden the welfare system.

- Albania has ratified and is successfully implementing the majority of international conventions on migrants workers. Although it is typical migrant-sending country, Albanian has almost complete legal framework on migrant workers.

- There are no legal provisions that directly address the migrants gender perspective and gender equality.

- The communication of Border and Migration police with foreigners entering the country irregularly needs to be improved through recruitment of personnel that speak foreign languages, offering courses for this purpose, or by hiring part-time persons who speak these languages, because provision of information in the native or in a language a migrant understands is an important human rights for foreigners entering Albania irregularly.

- The psychosocial service personnel across the country need additional specific training to be able to better address challenges of foreigners and migrant workers, particularly those deprived of their liberty.

- Medical doctors, nurses and hospital and healthcare personnel need additional specific training to be able to improve services of foreigners and migrant workers in the country by better understanding their respective health risks and health social determinants as well as the culture's impact on health and illnesses.

- The Ombudsman should make direct reference to the protection of the rights of migrants in Albania, in addition to property, housing, consumer or environment rights, and their rights to address and require assistance and support from the institution.

- The Albanian Helsinki Committee should make direct reference to the protection of the rights of migrants in Albania, in addition to the rights of natives and Albanian emigrants in receiving countries, and their rights to address and require assistance and support from this institution.

\section{References}

Law No. 108/2013 "On foreigners" is fully approximated with the Regulation (EC) no. 810/2009 of the European Parliament and of the Council of 13 June 2009 "Establishing a Community Code on Visas (Visa Code)" CELEX no.32009R0810, Official Gazette of the European Union, Series L Nr. 243, dated, 15.9.2009, pages 1-58.

Assessment on the protection of the Rights of Migrant Workers in Albania. (Prepared for the International Organization for Migration IOM June 2016.

Extended migration profile for Albania 3013

Regulation (EC) No 562/2006 of the European Parliament and of the Council of 15 March 2006 establishing a Community Code on the rules governing the movement of persons across borders (Schengen Borders Code) (OJ L 105, 13.4.2006, pg. 1) Celex-No. 3 2006 R 0562

The Charter of Fundamental Rights of the European Union 2000.

EU Directive for Racial Equality 2000/43 / EC..

Global approach to migration and mobility 2005.

Blue Card Directive 2009.

Employer Sanctions Directive for 2009 .

Directive to permit unified, 2011.Seasonal workers directive 2014.

Directive on intra-corporate transfer of skilled workers from non-EU countries, 2014.

European Agenda for Migration 2015.

Regulation (EC) No 296/2008 of the European Parliament and of the Council of 11 March 2008 (OJ L 97, 9.4.2008, pg. 60; CELEX Nr. 32008R0296)

Regulation (EC) No 81/2009 of the European Parliament and of the Council of 14 January 2009 (OJ L 35, 4.2.2009, pg. 56; CELEX Nr. 32009R0081)

Regulation (EC) No 810/2009 of the European Parliament and of the Council of 13 July 2009 (OJ L 243, 15.9.2009, pg. 1; CELEX Nr. 32009R0810)

Regulation (EC) No 265/2010 of the European Parliament and of the Council of 25 March 2010 (OJ L 85, 31.3.2010, pg. 1; CELEX Nr. 32010R0265) 


\section{Deported and Charter Operations}

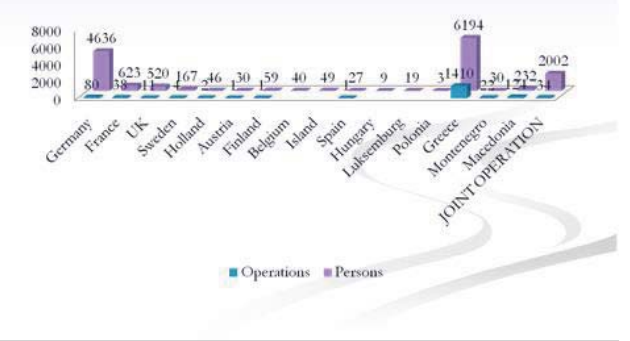

ILLEGAL MIGRANTS BY NATIONALITIES

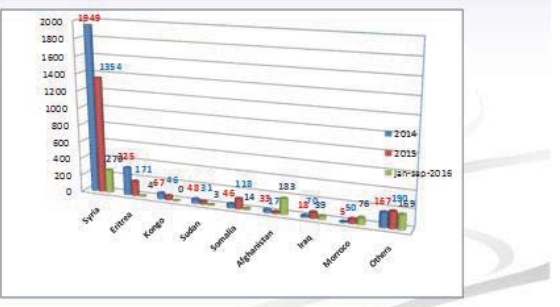

\section{Foreign nationals treated in the}

\section{Closed Reception Center}

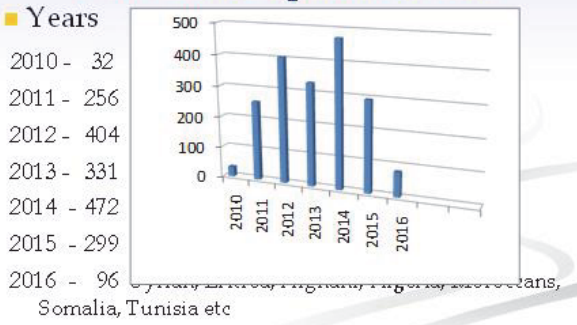

\section{Conclusion and Recommendations}

Albanian institutions have improved significantly in their handling of migratory flows, however, their capacity building needs support in key areas such as identification of types of immigrants (interpreters, motives, legal status) and their accommodation in adequate structures to prevent these flows continuing and not serve as a transit route.

- Data on foreigners in Albania put more emphasis on asylum-seekers, refugees and persons who enter the country irregularly and less so on migrant workers and their social, economic, political and cultural rights.

- The power of the Ministry of Social Welfare and Youth and it agencies in shaping migration polices and addressing migrant workers women rights in Albania has been reduced and the power of the Ministry of Internal Affairs and its institutions and agencies has been increased during the last years. The treatments of 
for achieving Albania goals on its way to integration. For a better identification with the support of ICITAP, an American project for assisting the State Police is designed FER (Foreign Electronic Registry) which serves to identify and record entry and exit of foreign nationals caught illegally. This registry dramatically improves the work of border police and migration as well as a recording of people who are caught crossing the border illegally, or those seeking international protection (identification made by declarations freely, picture, fingerprint). This system is installed at all border crossing points, the Regional Border and Migration Directorate and General Directorate of Border and Migration. The main international sources for the implementation of the rights of migrants entering the country illegally are the reports of the Special Reporter of the UN and the UNHCR. In 2013, the Special Reporter on migrants, in addition to respecting the rights of migrants, stressed the need for adequate information and documenting the best cases of persons seeking protection in Albania. Special Reporter on migrants in Albania recommended that migrant children should not be subject to detention, or it can occur only in very exceptional cases, as a last resort and for a very short period of time. The Office of the UN High Commissioner for Refugees (UNHCR) has urged Albania to provide interpreters for people seeking protection in the country. The report by the High Commissioner UN Office on Human Rights, under paragraph 15 (b) of the annex to Council resolution on human rights $5 / 1$ and paragraph 5 of the annex to Council resolution 16/21, Albania 13 February 2014. The main domestic source of statistics on foreign nationals trying to enter Albania improperly is the General Directorate of Border and Migration, Asylum Directorate of the Ministry of Internal Affairs. According to this source, about 18 percent of them, 471 of 2,618 were refused to enter in Albania for several reasons, such as lack of documents to prove identity, previous violation of residence rules in Albania, lack of financial support, not justifying the reason of entering the country, etc. Another national source of information for the treatment of migrants entering the country illegally is the Albanian Helsinki Committee. During the last years the Albanian Helsinki Committee conducted three investigative missions in Albania-Greece border checkpoints to monitor the treatment of foreigners entering the country illegally.

Monitoring reports through years are as follows:

- Usually irregular migrant women are treated by women police officers, which make about 50 percent of the police staff in Tirana International Airport and 25 percent of police officers in the port of Durres;

- Professional capacities of police officers which serve to irregular migrants have not increased;

- Police needs more specific training on the legislation on human rights and for protection procedures of irregular foreign migrants from maltreatment;

- There exists a good cooperation between Albanian and Greek police for the treatment of irregular migrants who cross the Albanian- Greek border.

- To be improved the manner and security elements regarding the permit of stay of foreign citizens in Albania.

- Albania should adopt a Strategy and an Action Plan on Migration, taking into consideration the implementation of the previous Strategy. It should be monitored closely the implementation process of the Strategy and of the Action Plan for the reintegration of the returnees;

- Strengthening of capacities for the management of migration;

- Improvement of reception premises such as in BCP as well as within the territory.

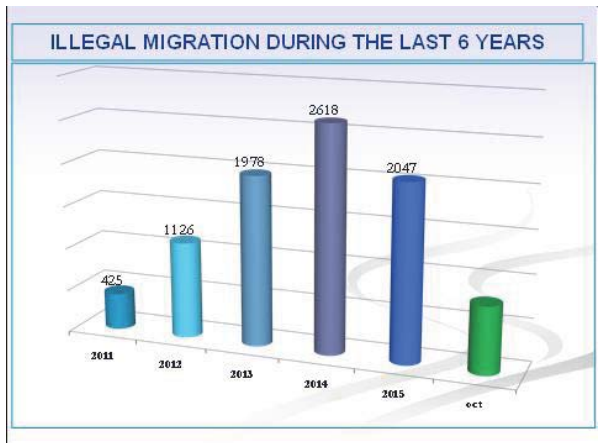


law", as well as:

3. Article 25, where is mentioned that "No one can be subject of torture, expulsion or cruel treatment, inhuman or humiliating".

This relates not only to the internal situation in neighbouring countries, but also the self knowledge of the asylum system and the treatment of foreigners in countries affected by wars or conflicts, external and internal, such as Iraq, Libya, Egypt, Afghanistan, Congo and Syria with over 2 million refugees fled the country, speak a lot about migratory flows towards more peaceful areas of the world, where the European Union stands. But not only that, the difficult economic situation and above all any standard treatment of irregular foreigners caught or found on Greek territory, is the primary reason for multiple flows of foreigners who can come to Albania. The events of 2016, the arrival of migratory flows near the Albanian border Greece, Italy, Macedonia has shown that even for the EU member states is a difficult managing massive flow as great as in reception, conducting the selection procedure, accommodation and implementation of standards previously adopted by member countries. Acceptance of German nationals who come from countries at war did have a large increase in the flow at the external border of the EU and difficulty in movement of these citizens in the countries of destination, or in the distribution of quotas adopted previously by member countries. Hungary for example, which does not allow passage of nationals of third countries outside the quota set (by placing military forces and set up metal fences to prevent the uncontrolled movement or decision of Austria for closing the border for several days and accepting only the citizens who struggle in countries like Syria, Iraq made that have an impact on all countries involved in this route, especially in Serbia and Macedonia. Facing the difficulty to identify the nationals of third countries and some of them by not seeking international protection in the first country of EU (in contradiction with the Convention in Dublin) but wanting to go to the countries of destination as e .x. Germany some of them try to go to EU countries, but another part is ready to use transit through Albania using other routes versus unacceptable possibility of returning to their country or in Greece.

\section{Methods}

Primary data were collected from the following activities: meeting with immigration officials at various levels, brainstorming sessions focusing on the key legal and institutional issues; field assessment of procedure applications and periodical monitoring.

\section{Results and Discussion}

Many immigrants come from EU borders (Greece) and non-EU borders (Macedonia), to use Albania as transit towards other EU countries such as Germany. This is valid for both asylum seeker fleeing wars and economic immigrants. There are also cases of human trafficking of people against their will and unaccompanied minors. Albanian institutions have been capable to provide adequate treatment of immigrants with the assistance of UN bodies and funds from the EU, in terms of screening and identification, as well as offering temporary humanitarian support (food, shelter and medical assistance). The role of State Police is crucial, in its collaboration with Frontex in complying with EU border and immigration rules.

Related to the irregular foreign citizens treated to the Closed Centre of Kareç:

$\begin{array}{cccc}\text { Year } & \text { Total } & \text { Males } & \text { Females } \\ 2013 & 331 & 294 & 37 \\ 2014 & 472 & 412 & 60 \\ 2015 & 299 & 278 & 21 \\ 2016 & 96 & 66 & 30\end{array}$

Foreign citizens selected as asylum seekers by Border and Migration Police and sent to the National Asylum Seekers Centre in Tirana.

$\begin{array}{ll}\text { Year } & \text { Total } \\ 2013 & 158 \\ 2014 & 298 \\ 2015 & 135 \\ 2016 & 172\end{array}$

These are citizens who have not requested international protection and in the Republic of Albania are at the irregular category. At this context, it is very important the training with knowledge of concepts such as third safe country and the changes that can be done, depending on the circumstances and developments, it is a very important advantage 